UNIVERSIDADE DE SÃO PAULO

FACULDADE DE FILOSOFIA, LETRAS E CIÊNCIAS HUMANAS

DEPARTAMENTO DE SOCIOLOGIA

PROGRAMA DE PÓS-GRADUAÇÃO EM SOCIOLOGIA

LUIZ VICENTE JUSTINO JÁCOMO

\title{
AS RELIGIÕES DA POLÍCIA:
}

RELIGIÃO E RELIGIOSIDADE NA POLÍCIA MILITAR

DO ESTADO DE SÃO PAULO

VERSÃo CORRIGIDA

SÃO PAULO

2016 
UNIVERSIDADE DE SÃO PAULO

FACULDADE DE FILOSOFIA, LETRAS E CIÊNCIAS HUMANAS

DEPARTAMENTO DE SOCIOLOGIA

PROGRAMA DE PÓS-GRADUAÇÃO EM SOCIOLOGIA

\section{AS RELIGIÕES DA POLÍCIA:}

\section{RELIGIÃO E RELIGIOSIDADE NA POLÍCIA MILITAR \\ DO ESTADO DE SÃO PAULO}

\section{Luiz Vicente Justino Jácomo}

Dissertação de Mestrado apresentada ao Programa de PósGraduação em Sociologia do Departamento de Sociologia da Faculdade de Filosofia, Letras e Ciências Humanas da Universidade de São Paulo para a obtenção do título de Mestre em Sociologia

Orientador: Prof. Dr. José Reginaldo Prandi

\section{VERSÃo CORRIGIDA}

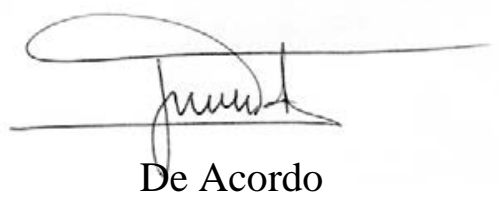

Prof. Dr. José Reginaldo Prandi

SÃO PAULO

2016 
Para Cristina, Vicente, Ana e Jane, os dias todos. 


\section{Resumo}

A profissão de policial militar e a religião são temas que, aparentemente, têm pouca interação entre si. Comumente, imagina-se haver uma incompatibilidade entre essas duas categorias, uma vez que a violência cotidiana a que são submetidos profissionais da polícia se confrontaria diretamente com o preconizado pelas éticas religiosas, principalmente aquelas mais pacifistas. Disso decorre que as interpretações das especificidades do religioso em um contexto militar acabam por enfatizar o discurso dos envolvidos nessa dupla identidade, furtando-se de tentar compreender as disputas envolvidas nesse cenário. Neste trabalho, proponho uma alteração nas escalas de observação desta realidade, tomando como objeto de pesquisa os grupos religiosos que atuam na Polícia Militar do Estado de São Paulo: os evangélicos PMs de Cristo; os PMs de Axé, adeptos das religiões afro-brasileiras; os PMs a Caminho da Luz, da vertente kardecista e o serviço de capelania católica. Minha intenção é analisar e compreender quais as estratégias utilizadas por esses grupos na disputa por seguidores, credibilidade e legitimidade junto ao comando da corporação e da instituição policial como um todo.

\section{Palavras-chave:}

Sociologia da Religião; Polícia Militar; Religiões da Polícia; Capelania; Religião e Estado 


\begin{abstract}
The military police profession and religion are subjects that apparently have little interaction with each other. Commonly, there is a mismatch between these two categories, since the daily violence to which police professionals are submitted is directly confronted with the religious ethics, especially those more pacifists. It follows that the interpretations of religious specificities in a military context tend to emphasize the speech involved in this double identity, not seeking to try to understand the disputes involved in this scenario. In this work, I propose an amendment on the scales of observation of this reality, taking as object of research religious groups working inside the military police of the State of São Paulo: Evangelicals PMs of Christ; the PMs of Axé, adherents of Afro-Brazilian religions; the PMs in the Path of Light, formed by Kardecists, and the Catholic Chaplaincy Service. My intention is to analyze and understand the strategies used by these groups in dispute over followers, credibility and legitimacy from the command of the Corps and the police institution as a whole.
\end{abstract}

Keywords: Sociology of Religion; Military Police; Religions of Police; Catholic Chaplaincy; Religion and State 


\section{Agradecimentos}

É grande o esforço que faço agora, ao redigir essas linhas finais, para remontar as redes de relações que me ajudaram, senão permitiram, concluir esse trabalho. Pensando nesses dois anos que passei pesquisando, o que me vem à cabeça é uma infinidade de relações de carinho, amizade e companheirismo, suportes fundamentais da minha existência que me permitiram chegar até aqui.

Quero começar agradecendo aos professores da Unesp-Marília, Luís Antônio Francisco de Souza e Antônio Mendes da Costa Braga. O primeiro foi responsável por me ajudar a traçar as primeiras linhas de um projeto de pesquisa, cuja temática eu desdobraria e trataria nessa dissertação. O segundo foi aquele que me deu ânimo e disposição para continuar, justamente em uma época em que eu era só dúvidas e incertezas. Vocês foram essenciais para o início da minha história na Universidade de São Paulo. Meu muito obrigado a vocês.

Em relação à transição entre a Unesp e a USP, quero expressar a minha mais profunda e eterna gratidão a uma pessoa que, talvez no momento mais difícil pelo qual jamais passei, estendeu a mão com toda a generosidade desse mundo: a professora Dra. Jacqueline Sinhoretto. Através do seu sorriso e coração abertos, pude me sentir novamente aceito e acolhido por um grupo que, liderado por ela, têm, cada um, individualmente, a minha admiração irrestrita até hoje. Obrigado a vocês do Grupo de Estudos sobre Violência e Administração de Conflitos pela acolhida e por me permitir acompanhar mais de perto o incrível trabalho de vocês; e muito obrigado, Jacque, de todo o coração, pelo gesto mais significativo que reconheço nessa caminhada. Obrigado ainda por se dispor a ler e a discutir o meu trabalho, tanto na qualificação como na defesa. É uma honra e uma alegria.

Agradeço especialmente ao professor Dr. Ricardo Mariano por ter permitido que eu trilhasse boa parte do meu mestrado em sua companhia. As relações profissionais que traçamos só serviram para aprofundar a admiração que já vinha de 
longa data, e é praticamente impossível descrever todo o crescimento pessoal e intelectual que essa proximidade me trouxe. Fico honrado por você ter aceitado participar da minha qualificação e defesa, e me sinto privilegiado por poder contar com a sua companhia nessa trajetória. Obrigado!

Agradeço aos policiais, sacerdotes, religiosos e membros dos grupos que pesquisei neste trabalho. Sem o apoio e a confiança de vocês não teria sido possível realizar essa pesquisa. Meu muito obrigado aos policiais Suzuki, Joel, Xavier, Mário Filho, Sugar Ray e Ronilson. Agradeço especialmente ao Babalorixá Flávio de Yansan, à Ekedi Andrea de Yemanjá e ao Ogan Paulinho de Oxaguiã, pela generosidade e disposição em ajudar. Que a minha visão desencantada de religião não permita que eu deixe de ver o brilho na existência e no trabalho sincero que vocês todos realizam. Muito obrigado!

Agradeço também aos membros do grupo de estudos que se reúne mensalmente sob coordenação do Prof. Dr. José Reginaldo Prandi, e do qual faço parte. Pessoas cruciais no desenvolvimento e nas transformações intelectuais que passei nessa inserção na sociologia da religião. Foi através das discussões e das leituras feitas em conjunto que consegui, ao menos inicialmente, me inserir de modo mais incisivo nessa temática, e tenho muito orgulho que isso tenha sido feito na companhia de vocês. Um muito obrigado a cada um de vocês: Célia Arribas, Daniela Guertzeinstein, Guilherme Borges, João Luiz Carneiro, Milton Bortoleto, Mônica Schettini, Massimo Bonato, Renan William dos Santos, Ricardo Mariano e Thiaquelliny Teixeira. Deixo também um agradecimento especial à Lena, pela companhia sempre leve e divertida.

Agradeço aos colegas da disciplina de Análise de Projetos, aos quais tenho afeto e gratidão pela ajuda nos primeiros momentos em terras paulistanas: Renan, Jayme, Aline, Fabiana, Vanessa, Thiago, Veridiana, Leandro e Camila. Muito obrigado pela recepção de vocês.

Outros amigos, já de longa caminhada, também foram importantíssimos neste processo. Agradeço aos irmãos José Luiz Pimenta e Flávio Rafael Del Santo, pela amizade de uma vida; aos amigos Thiago, Hélio e Marcelo, pela melhor adolescência 
que eu poderia ter tido, graças a companhia de vocês; aos companheiros Pedro Bianchi e Tiago Brentan, pela existência e experiência compartilhadas em toda a sua força; ao querido amigo Cadu Machado, pela prazerosa companhia em todos os momentos, mesmo à distância; ao sempre presente Gustavo Demétrio, a mais grata recompensa que a cidade de São Paulo poderia me trazer; a Bruno Fernandes, pela sensibilidade e reciprocidade que tanto conforta; ao professor Yan Cambuí, pelas tardes conversando lá no clube da esquina. Sei que, enquanto não acabarmos com toda a cerveja deste mundo, continuaremos tentando até conseguir. Amo vocês, muito.

Agradeço também a minha família, pilar da minha existência e meu refúgio: minha irmã Ana Cristina, meus pais, Vicente e Cristina, e minha companheira Jane, a quem dedico essa dissertação. Sem vocês simplesmente não daria. Ao meu avô Lázaro, pela sabedoria que sempre me inspira, e ao meu tio Maurício, um autêntico Buendía, faço um agradecimento especial. Também agradeço à minha querida tia Cristiani e aos primos Bruno e Luciano, por todo o carinho. É só no caos dessa nossa família que eu consigo encontrar sossego e paz para prosseguir. Amo vocês!

Por fim, meu agradecimento maior ao querido orientador Prof. Dr. Reginaldo Prandi. Não consigo encontrar palavras para descrever o quanto me sinto privilegiado e feliz por ser orientado por você. Seja nos agradáveis momentos em que você, com toda a sua generosidade, me recebia em sua casa para as reuniões; seja quando discutíamos pontos teóricos e metodológicos dessa pesquisa, todos os momentos em que pude estar próximo de você foram simplesmente fantásticos. Meu muito obrigado, do fundo do coração.

Por fim, essa pesquisa só foi possível graças ao apoio financeiro do Conselho Nacional de Desenvolvimento Científico e Tecnológico - CNPq. Sem esse fundamental apoio, não teria sido possível conciliar as diferentes frentes de pesquisa de campo que resultaram no trabalho que aqui apresento. 
— Às vezes eu penso: seria o caso de pessoas de fé e posição se reunirem, em algum apropriado lugar, no meio dos gerais, para se viver só em altas rezas, fortíssimas, louvando a Deus e pedindo glória do perdão do mundo. Todos vinham comparecendo, lá se levantava enorme igreja, não havia mais crimes, nem ambição, e todo sofrimento se espraiava em Deus, dado logo, até à hora de cada uma morte cantar. Raciocinei isso com compadre meu Quelemém, e ele duvidou com a cabeça: - "Riobaldo, a colheita é comum, mas o capinar é sozinho..." - ciente me respondeu.

(Riobaldo, em Grande Sertão: Veredas, de João Guimarães Rosa) 


\section{LiSTA DE AbreViaturas S E Siglas}

$\begin{array}{ll}\text { ACMEB } & \text { Aliança Pró-Capelania Militar Evangélica Brasileira } \\ \text { AG } & \text { A Gaxéta } \\ \text { ALESP } & \text { Assembleia Legislativa do Estado de São Paulo } \\ \text { AOC } & \text { Associação dos Oficiais Cristãos } \\ \text { APMBB } & \text { Academia de Polícia Militar do Barro Branco } \\ \text { APMESP } & \text { Associação dos Policiais Militares do Estado de São Paulo } \\ \text { BOPE } & \text { Batalhão de Operações Especiais } \\ \text { CAS } & \text { Centro de Assistência Social } \\ \text { CASJ } & \text { Centro de Assistência Social Jurídica } \\ \text { CASJR } & \text { Centro de Assistência Social, Jurídica e Religiosa } \\ \text { CF } & \text { Constituição Federal } \\ \text { CNBB } & \text { Comissão Nacional de Bispos do Brasil } \\ \text { CNPq } & \text { Conselho Nacional de Desenvolvimento Científico e Tecnológico } \\ \text { COSARFA } & \text { Comissão dos Serviços de Assistência Religiosa das Forças Armadas } \\ \text { DH } & \text { Direitos Humanos } \\ \text { DOE } & \text { Diário Oficial do Estado } \\ \text { DPCDH } & \text { Divisão de Polícia Comunitária e Direitos Humanos } \\ \text { ESSd } & \text { Escola Superior de Soldados } \\ \text { ESSgt } & \text { Escola Superior de Sargentos } \\ \text { FEB } & \text { Força Expedicionária Brasileira } \\ \text { HPM } & \text { Hospital da Polícia Militar } \\ \text { IBASE } & \text { Instituo Brasileiro de Análises Sociais e Econômicas } \\ \text { ISER } & \text { Instituto de Estudos da Religião } \\ \text { IURD } & \text { Igreja Universal do Reino de Deus } \\ \text { NAFRO-PM } & \text { Núcleo das Religiões Afro-Brasileiras da Polícia Militar de São Paulo } \\ \text { OM } & \text { Ordinariado Militar } \\ \text { ONCC } & \text { Ordem Nacional de Capelania Cristã } \\ \text { PMDF } & \text { Polícia Militar do Distrito Federal } \\ \text { PMERJ } & \text { Polícia Militar do Estado do Rio de Janeiro } \\ \text { PMESP } & \text { Polícia Militar do Estado de São Paulo } \\ \text { PMGO } & \text { Polícia Militar do Estado de Goiás } \\ \text { QAE } & \text { Quadro de Auxiliares de Enfermagem } \\ \text { QOC } & \text { Quadro de Oficiais Capelães } \\ \text { QOM } & \text { Quadro de Oficiais Médicos } \\ \text { SAR } & \text { Serviço de Assistência Religiosa } \\ \text { UDUD } & \text { Assembleia de Deus dos Últimos Dias } \\ \text { UEPMERJ } & \text { União dos Evangélicos da Polícia Militar do Estado do Rio de Janeiro } \\ \text { UMCEB } & \text { União dos Militares Cristãos Evangélicos do Brasil } \\ \text { UPP } & \text { Unidades de Polícia Pacificadora } \\ & \end{array}$




\section{SUMÁRIO}

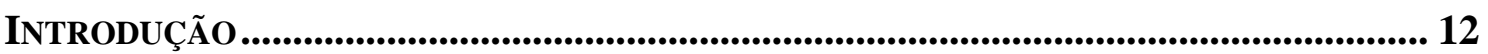

Segurança pública, violência e religião como notícia ............................................. 12

Segurança pública, violência e religião na literatura acadêmica ................................. 19

A presente pesquisa: objetivos e procedimentos ....................................................... 34

CAPÍtUlo 1: A POLÍ́CIA MILITAR E OS GRUPOS RELIGIOSOS ......................................... 40

Da corporação militar ao policial sujeito da ação social: uma análise sociológica .... 40

As escolas de formação de policiais militares de São Paulo: o sistema de duplaentrada e a formação dos grêmios religiosos .................................................. 45

CAPÍTULO 2: OS RELIGIOSOS ORGANIZADOS NA PMESP ....................................... 50

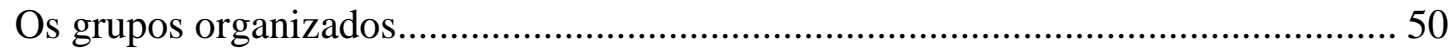

Os católicos e o serviço de capelania militar.................................................................. 53

Os evangélicos: a expansão e hegemonia dos PMs de Cristo .................................... 64

Os espíritas kardecistas: a discrição e a regularidade dos PMs a Caminho da Luz ... 80

Os afro-brasileiros: os conflitos e tensões dos PMs de Axé........................................ 82

CAPÍtUlo 3: A RELIGIÃo, A POLÍCIA E O POLICIAL ................................................. 90

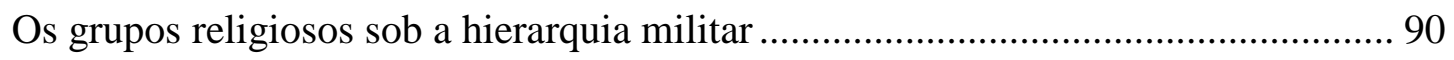

A religião como justificativa da tarefa policial ...................................................... 97

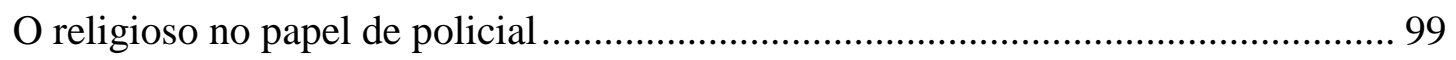

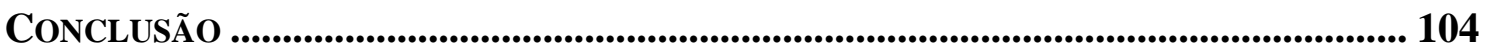

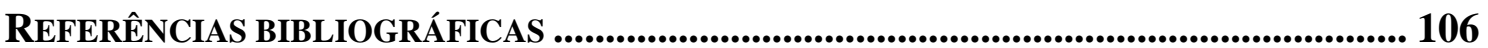




\section{INTRODUÇÃo}

\section{Segurança pública, violência e religião como notícia}

A confusa relação de interesses de agentes da segurança pública religiosos frequentemente vem à tona nos principais meios de comunicação digital e impresso do país. O julgamento, no entanto, varia - e muito - conforme a síntese dessas dimensões se manifesta na atuação cotidiana destes agentes. Apresentarei, nesse momento, um não tão breve balanço da cobertura midiática de algumas dessas ocasiões.

A notícia que mais repercutiu na mídia e que inflamou todo um debate entre os interessados dessas áreas - policiais e agentes de segurança pública, líderes religiosos e ativistas em defesa da laicidade do Estado - com certeza foi a parceria da Polícia Militar do Distrito Federal com a Universidade da Família, instituição paulista de orientação evangélica que atua no mercado de treinamento e editoração de materiais com conteúdo religioso. O curso, denominado "Programa Educação Moral”, previa a aplicação de aulas e palestras visando orientar os policiais militares do Distrito Federal sobre questões como casamento, família e finanças domésticas.

O jornal Folha de S. Paulo trouxe a questão já levemente polemizada na manchete: "Em Brasília, PM é liberado do trabalho para estudar a bíblia” (Folha de S. Paulo, 24/09/2013). No lead da matéria, a afirmação de que a finalidade do curso era "para policiais aprenderem a criar seus filhos e ater um casamento em acordo com 
princípios bíblicos”, através de cinco módulos: “Como criar seus filhos, Homem ao máximo, Mulher Única, Aliança e Como chegar ao fim do mês”.

A matéria toca em três pontos importantes: o primeiro, o fato de que o curso seria ministrado durante o expediente, nas dependências da PM e com o custeio do material didático bancado pela corporação. Em segundo lugar, problematiza as noções de "homem máximo” e “mulher única” dos conteúdos e, por último, o fato de que não haveria, no desenho do projeto piloto da iniciativa, a perspectiva de cursos para outras religiões. Questionado sobre esses pontos, o comando da Polícia Militar do Distrito Federal (PMDF) respondeu de forma um tanto lacônica: “A ação da Capelania Militar da PMDF não implica que um policial militar seja liberado de trabalhar para fazer cursos de qualquer religião. O programa é institucional, não é de uma religião”, afirmou o comando em nota enviada ao jornal. O comando afirmou, ainda, que o curso serviria de “apoio aos militares, ajudando a minimizar o grande estresse físico e emocional da atividade policial”.

O jornal Correio Braziliense, de alcance mais reduzido, já havia feito a cobertura da notícia na sua edição impressa, de forma tanto mais crítica. No subtítulo da manchete, afirmava que "sem levar em conta o Estado laico, a Polícia Militar do DF oferece cursos baseados na Bíblia e voltados para a vida familiar. Especialistas criticam a iniciativa” (Correio Braziliense, 31/08/2013). Na reportagem, os jornalistas confrontaram a visão do capelão evangélico que viabilizou o projeto, o Capitão Gisleno de Faria, com o professor de Filosofia da Religião da Universidade de Brasília (UnB), Agnaldo Cuóco Portugal.

Na visão do capelão, a iniciativa teria nascido de uma demanda dos próprios policiais. Afirma ele: "Percebemos que certos problemas familiares têm afetado o trabalho do policial, e a intenção é reforçar o respeito aos direitos humanos, à ética profissional, ao cientificismo e à honestidade”, ao mesmo tempo em que confirma a versão de que os policiais inscritos e matriculados seriam dispensados para o curso, caso estivessem em serviço. Já para o pesquisador, a questão é problemática ao relacionar o conteúdo religiosamente orientado do curso e a laicidade estatal. 
O modo como a instituição está promovendo é questionável sobre a laicidade do Estado. Dar ao policial cristão a oportunidade de refletir melhor sobre os princípios da fé pode ser uma boa estratégia, além de louvável, mas a questão é, se o Estado pode oferecer esse tipo de curso, até que ponto isso é um estudo estritamente acadêmico?

No entanto, é outro pesquisador ouvido pelos jornalistas que coloca a questão nos termos - a meu ver, diga-se - corretos. O doutor em Direito Constitucional também pela UnB, Cristiano Paixão, questiona:

Por que não o Alcorão? Por que não textos sagrados do espiritismo ou africanos? Se um policial está passando por problemas na família, a PM pode oferecer ajuda psicológica ou cursos de informação continuada. A meu ver, é uma conduta inconstitucional e bastante preocupante.

Na resposta do capelão, a velha "laicidade à brasileira”, na feliz expressão cunhada pelo sociólogo Ricardo Mariano (2011). Gislano afirma, em sua defesa que o “Estado é laico, mas o cidadão é religioso”. E continua: “o fato de ser laico não quer dizer que a religiosidade tenha de ser execrada da existência. As pessoas têm a sua religiosidade, e isso pode ser utilizado para o benefício do Estado”.

Outro capelão evangélico da PMDF. Olavo Freitas Mendonça, considerou a matéria publicada pelo jornal brasiliense uma “campanha anticristã contra policiais da PMDF”. O que para ele seria uma ótima notícia - o curso em parceria com a Universidade da Família -, "pois nada melhor do que em um país com graves problemas morais e éticos a principal corporação policial de Brasília oferecer um curso em que se foque os valores morais, tão caros e escassos no Brasil”, foi tratada de forma ofensiva e distorcida.

Na nota pública, divulgada no diário digital do capelão e replicada pela Associação dos Oficiais da Reserva Remunerada e Reformados da Polícia Militar do Distrito Federal e do Corpo de Bombeiros Militar do Distrito Federal (ASSOR), o capelão alega que as críticas ao projeto encontram respaldo no artigo $5^{\circ}$ da Constituição Federal (CF), que trata da inviolabilidade da liberdade de consciência e de crença” no Estado brasileiro. Alega ainda, nas suas palavras, que 
o argumento de que o Estado é laico nada mais é do que a velha perseguição anticristã travestida de politicamente correto. Afinal é impossível negar que em um pais onde $90 \%$ da população acredita em Deus e mais de $80 \%$ são cristãos e que foi descoberto, fundado e construído por pessoas com a sua moral e fé é de se esperar que a sua influência esteja em toda a sociedade, inclusive nas Corporações policiais e militares ${ }^{1}$.

As estimativas do capelão são, no mínimo, curiosas. Nem os dados do Censo confirmam que a fé cristã é professada por $80 \%$ da população, nem há indícios que o deus em que creem os $90 \%$ da população é o Deus da tradição judaico-cristã. Para o capelão, o que estaria em curso e por trás da abordagem do jornal de Brasília seria a ideologia “anticristã e anti-família do governo" para o desmonte das instituições que sustentariam a sociedade. Vale a pena conferir o argumento final de sua nota, apesar da citação longa:

O que ficou claro nesse episódio é que o foco da reportagem não é o bem-estar dos policiais da Capital do Brasil, que muito se beneficiarão dos cursos oferecidos pela capelania da PMDF, nem os valores morais defendidos por grande parte da população brasileira, nem mesmo o Estado laico, que na sua Constituição e leis apoia e determina ações desse tipo, mas o foco da reportagem é, mais uma vez, denegrir a imagem da Polícia Militar do Distrito Federal e promover a agenda anticristã. Para azar deles e para sorte da população de Brasília os policiais militares sempre combaterão o crime com Fé e esperança, pois, afinal, para o Cristão a sua Esperança tem nome, chama-se Jesus Cristo.

O argumento de que o curso era voltado para a esfera privada dos policiais militares, para a boa condução da família e das finanças se transforma, na fala do capelão, no combate ao crime com fé e esperança. Mas seria justamente esse combate ao crime santificado que culminaria em dois episódios que trariam uma agenda negativa à relação religiosidade - policiamento.

No primeiro episódio, ocorrido em setembro do ano passado, dois policiais da PMESP aparecem violando uma oferenda de umbanda em uma encruzilhada. No vídeo, gravado pelos próprios policiais, é possível ver quando um deles se aproxima

1 A nota pública pode ser acessada em http://www.assor.com.br/index.php/component/k2/item/258jornal-inicia-campanha-anticrista-contra-policiais-da-pmdf. Acesso em 02 de agosto de 2015. 
da oferenda afirmando que "vai mostrar como polícia militar, guerreiro faz”. Enquanto se aproxima da oferenda, dirige-se a outros policiais da corporação, que provavelmente iriam ter acesso ao vídeo, como "bundões”, e diz que vai “ensinar como se faz”. Pega, então, uma garrafa de cachaça do chão e bebe pelo menos quatro vezes, ao que o outro policial, filmando, instiga-o a tomar tudo, duvidando de que ele “teria coragem”. Sempre ressaltando que isso é “o que o verdadeiro policial militar faz" e saudado como "guerreiro" pelo policial que filmava no primeiro momento, o primeiro policial toma a câmera e chuta a oferenda, finalizando a gravação.

A própria PMESP não se manifestou sobre o ocorrido, nem os líderes religiosos da corporação. Canais de notícias evangélicos, como Gospel+, Gospel Prime, Genizah Virtual, que no caso do curso ministrado pela capelania da PMDF saudaram a iniciativa, calaram-se em relação ao ocorrido. O destaque foi dado pelo canal de notícias online UOL, que, em um título infeliz para um episódio lamentável, vinculou o vídeo de forma leve e descontraída, com a manchete "PM bebendo cachaça do despacho de macumba” ${ }^{2}$. Nos fóruns de discussão sobre abordagem e atuação policial, a repreensão ao ato dos policiais era, majoritariamente, de que não se deve beber em serviço. Um chute na santa sempre vale mais que um chute na oferenda.

O segundo caso aconteceu mais recentemente, em fevereiro deste ano. Neste, cinco policiais militares da Polícia Militar do Estado de Goiás (PMGO) foram filmados conduzindo um ritual de exorcismo em um homem visivelmente alterado pelo efeito do álcool. No vídeo, que dura pouco mais de 9 minutos, os policiais aparecem tentando imobilizar o sujeito, com alguma dificuldade e fazendo uso de pisões e técnicas de imobilização. Com a mão na cabeça, um dos policiais se dirige diretamente à Satanás, que estaria possuindo o corpo do homem, afirmando que "o sangue de Jesus é mais poderoso”.

Em determinado momento do vídeo, o homem chega a afirmar que "está machucando". Ao final da primeira fase do exorcismo, ainda se contorcendo, o

O vídeo pode ser conferido em http://mais.uol.com.br/view/e8arawzeul23/pm-bebendo-cachaca-dodespacho-de-macumba-04024D9B3662C0915326?types=A\&. Acesso em 02 de agosto de 2015. 
homem começa a chorar e pedir pela companhia do irmão. Ao ficar novamente agressivo, é imobilizado mais uma vez pelos policiais e a sessão é retomada, o que viria a acontecer pelo menos mais duas vezes até o final do vídeo, que é interrompido no meio da sessão. Trechos do vídeo foram exibidos nos principais telejornais da Rede Globo de televisão e o fato foi noticiado pelo jornal O Estado de S. Paulo. Para o jornal, a PMGO informou que o vídeo havia sido encaminhado para a Corregedoria, que iria analisar o conteúdo das imagens e verificar se as ações são passíveis de punição (O Estado de S. Paulo, 12/02/2014), o que não ocorreu até o momento.

Essas ações receberam duas críticas por parte de estudiosos da segurança pública, no segundo caso, e de movimentos em defesa das religiões e da cultura afrobrasileira, no primeiro. Os principais terreiros se manifestaram contra as agressões às suas crenças, mas não foi instaurado qualquer processo de investigação sobre o ocorrido. Na mídia gospel, que silenciou sobre os ataques às oferendas, os policiais filmados conduzindo o ritual de exorcismo são elogiados pela atuação e pelo discernimento, ao identificar a raiz demoníaca da agressividade do sujeito alcoolizado.

Mas a polêmica maior seria trazida pela relação com sinais invertidos entre religião e militarismo. Trata-se da chegada dos Gladiadores do Altar, movimento de jovens membros da IURD cuja estética é inspirada nos trejeitos e nas vestimentas militares e que atuava desde o final de 2014. Na apresentação do grupo, o folheto da IURD descrevia:

Em frente ao Templo de Salomão, jovens fardados e alinhados batem continência em sincronia. Embora carreguem consigo a disciplina de militares, trata-se de outro tipo de soldado: aqueles que lutam em nome da Palavra de Deus 3 .

A analogia com o militarismo, segundo a igreja, era baseada no fato de que, nos trabalhos missionários que esses jovens realizariam, os jovens deveriam servir ao reino espiritual tal qual os soldados servem à sua nação, em uma postura calcada na

3 Disponível em http://www.universal.org/noticia/2015/03/08/conheca-o-novo-projeto-gladiadores-doaltar-32332.html. Acesso em 10 de agosto de 2015. 
hierarquia e na disciplina. Junto com a divulgação impressa, a IURD lançou um vídeo nas redes sociais onde era possível ver um grande grupo de jovens marchando, com roupas verde-oliva, em direção ao púlpito da igreja, para onde bateriam continência e entoariam palavras de ordem.

O projeto foi muito mal recebido pela imprensa, líderes religiosos, parlamentares e por outras denominações religiosas, mesmo do meio evangélico. A acusação era de que a IURD estaria formando um exército fundamentalista, para lutar contra um inimigo que ninguém sabia ao certo qual era. Os adeptos das religiões afrobrasileiras, perseguidos históricos do proselitismo iurdiano, entenderam o recado e se mobilizaram. Vários grupos religiosos e movimentos de defesa de minorias protocolaram pedido de investigação ao Ministério Público, em mais de 26 estados. Na Bahia, cujo movimento foi encabeçado pelo Ilê Axé Casa de Oxumarê, o Ministério Público chegou a anunciar a instauração de inquérito civil, ao passo que o Ministério Público do Ceará disse não ter encontrado nada nas imagens que representasse indícios de intolerância religiosa ${ }^{4}$. A IURD afirmou que "as denúncias foram motivadas por má fé de jornalistas e praticantes de outras religiões”. Seu exército continua firme e forte.

Não resta dúvida de que cabe aos cientistas sociais da religião, devidamente comprometidos com a ciência e capazes de neutralizar os efeitos negativos que uma visão religiosamente interessada poderia trazer na análise dessas ocorrências, evidenciar - o que já é escancaradamente visível, diga-se - as causalidades envolvidas neste duplo processo, da abertura das porteiras institucionais para uma visão de atuação profissional mezzo laica, mezzo religiosa e dos ataques fundamentalistas às religiões do mal, do demônio, da perdição, que são, invariavelmente, as religiões dos outros. Mas, veremos, não é esse o tratamento que se tem dado à questão.

Mais informações em http://www.cartacapital.com.br/sociedade/exercito-da-igreja-universalpreocupa-religioes-afro-brasileiras-449.html. http://www1.folha.uol.com.br/poder/2015/03/1607108-religioes-de-raiz-africana-pedeminvestigacao-de-grupo-gladiadores-do-altar.shtml. Acesso em 10 de agosto de 2015 


\section{Segurança pública, violência e religião na literatura acadêmica}

A produção acadêmica que articula áreas da segurança pública em interface com a esfera religiosa é profícua nas ciências sociais da religião ${ }^{5}$. Profícua e variada, mas mais variada nas escolhas dos atores e agentes que elegem como objeto de análise - bandidos, ex-bandidos, agentes penitenciários, traficantes, policiais - do que com as religiões do campo religioso brasileiro que procura analisar, quase sempre os pentecostais ou sua vertente neo. Mas essa preponderância não é por acaso.

Há certo consenso sobre uma tripla causalidade envolvida nessa questão, aquela que articula periferia, violência e crime - ou “mundo do crime”, para utilizar uma expressão nativa mobilizada pelo sociólogo Gabriel Feltran (2008) - e pentecostalismo. Somado a isso, há a incisiva atuação dos pentecostais dentro dos presídios e penitenciárias brasileiras, que alteram significativamente as redes simbólicas de socialização dentro daqueles espaços. Sobre as periferias, afirma o sociólogo protestante Paul Freston, que

chegam a existir situações em que apenas duas instituições realmente funcionam em algumas regiões urbanas: o crime organizado e as igrejas pentecostais. Outras formas de religião organizada estão ausentes ou fracas, e o Estado também (Freston, 2011: 123).

Essa 'periferização' do pentecostalismo configuraria aquilo que a antropóloga Clara Mafra, inspirada nos estudos de Freston, chamou de “cinturão pentecostal”, essa faixa periférica que enveloparia um centro urbano católico e mais desenvolvido nas grandes cidades (Mafra, 2010). Já nas prisões, a socióloga Camila Caldeira Nunes Dias aponta que, no Censo Penitenciário realizado com mais de 58.000 detentos em 2002, 21,3\% dos entrevistados se declararam evangélicos, enquanto o Censo Brasileiro de 2000 apontava uma taxa de 15,5\% de evangélicos (Dias, 2005: 61), demonstrando uma maior propensão de adesão ao pentecostalismo entre os detentos.

Tomo emprestado de Pierucci (1999) a noção de “ciências sociais da religião” para me referir às pesquisas da área de antropologia e sociologia sobre o campo religioso. 
Ao buscarem uma explicação para esta propensão ao pentecostalismo nas prisões, os trabalhos de Dias ${ }^{6}$ e da antropóloga Eva Scheliga (2000) apresentam-se como os de maior fôlego, ainda que sob perspectivas diferentes. Dias aponta que o "severo código normativo existente na prisão" é implacável com os seus transgressores (estupros, dívidas, faltas de conduta, etc.), que podem ou buscar proteção administrativa, falha nos seus ilegalismos, ou tornarem-se “crentes”, já que o mesmo código de conduta destes detentos coloca os religiosos como "intocáveis". Segundo Dias, trata-se ou da

\begin{abstract}
transferência do preso ameaçado para outra cadeia - o que nem sempre resolve o problema, dada a troca de informações característica desse sistema social - ou, o que é mais comum, a sua transferência para o "seguro", que é também chamado de "prisão dentro da prisão" em decorrência de ser um local com mais restrições do que os demais e onde o preso permanece isolado do convívio com a massa carcerária, impedido de circular, a fim de não ter sua vida posta em perigo. Porém, uma outra forma de lidar com a situação quando o convívio com a massa se torna problemático, ou até mesmo impossível, é tornar-se crente. Isso porque, na igreja (nas celas dos "irmãos") ninguém é recusado ou impedido de permanecer - ao contrário, todos são bemvindos - desde que siga um modelo de comportamento religiosamente orientado (Dias, 2005: 148).
\end{abstract}

Bíblia como refúgio, enfim. Se o foco de Dias é a relação do preso converso em uma dimensão mais ampla, que engloba tanto os agentes da administração penitenciária quanto a dinâmica dos detentos em um contexto de interações sociais dentro da pais, Sheliga se preocupa mais com as transformações positivas que a pertença religiosa, especificamente a evangélica traria, ao mobilizar noções de "regeneração" e arrependimento. Sheliga, porém, também aponta a possibilidade de uma conversão interessada, como meio eficaz de proteção dentro dos presídios, mas considera estes relatos meros disparates de agentes penitenciários e diretores, de modo a depreciar a experiência de conversão dos presos (Sheliga, 2000: 75-79). Tais posturas se relacionam em muito com as teorias sociais mobilizadas pelas autoras para

\footnotetext{
$6 \quad$ Foi ao me deparar com este trabalho de Dias durante a graduação, no já longínquo ano de 2011, que tracei as primeiras linhas do que viria a ser a minha iniciação científica sobre os policiais evangélicos, que desenvolvi e ampliei nesta dissertação. É um trabalho, no mínimo, inspirador e corajoso.
} 
dar sentido à realidade da religião no sistema prisional. Dias, de uma perspectiva interacionista, foca o peso da totalidade institucional dos presídios sobre as interações, enquanto Sheliga, mobilizando os conceitos de campo e habitus como delineados por Pierre Bourdieu, acaba por valorizar a autonomia dos agentes dentro deste campo.

Há também uma corrente eminentemente fluminense, preponderantemente antropológica e etnográfica, que articula as dimensões da religião e da segurança pública para analisar a realidade carioca - interface a qual Carly Machado (2015) se refere como "campo de pesquisa sobre religião e cidade”. Com influência dos trabalhos de Alba Zaluar (1985, 1993), Cecília Mariz (1997) e Clara Mafra, uma geração de pesquisadoras passou a analisar as diversas redes de socialização nas periferias, relacionando a atuação dos movimentos de moradores, traficantes, agentes da ordem e líderes religiosos, particularmente das denominações pentecostais, que passam a ser objetos de análise a partir das "misturas” das realidades periféricas (Machado, 2013) ou de “exemplos bons para pensar” (Novaes, 2012).

Uma interessante pesquisa neste sentido foi conduzida pela antropóloga Carly Machado (2013) em uma comunidade do Rio de Janeiro, mais especificamente no Morro do Turano, na zona sul carioca. Machado aborda a figura do pastor Marcos Pereira, da Assembleia de Deus dos Últimos Dias (UDUD), e sua proximidade com os agentes da segurança pública das Unidades de Polícia Pacificadora (UPP) ${ }^{7}$. Mais precisamente, Machado foca na atuação do pastor enquanto estratégia articulada com os agentes de segurança pública estabelecendo um "fluxo de dependentes químicos” que são levados até a igreja pelos policiais a fim de receberem tratamento terapêutico e religioso, estratégia a qual a pesquisadora se refere como "parceria” (Machado, 2013: 3).

\footnotetext{
A implantação das UPP é uma política de segurança pública posta em prática a partir de 2008 nas comunidades do Rio de Janeiro, e tem como premissa a retomada de territórios das mãos de traficantes aliado à aproximação dos policiais militares das comunidades. Já somam, atualmente, 38 unidades espalhadas por todo o território carioca. Para informações institucionais, ver <www.upprj.com>. Acesso em 30 de julho de 2015,
} 
Fruto de “uma relação íntima entre crime e religião”, Machado aponta o efeito moralizante que os evangélicos em questão conferem aos dependentes químicos, efeito que “faz convergir a figura do 'drogado' com a do 'bandido', oferecendo [a eles] recuperação ao corpo e à alma, e ressocialização ao cidadão perdido no crime e no pecado” (p. 3). Nessa relação íntima, os agentes religiosos ocupam lugar de destaque na mediação e na conformação de uma rede que mescla assistência terapêutica religiosamente orientada e combate ao tráfico pelos agentes de segurança pública, “articulando intimamente o mundo da religião ao mundo do crime”, introjetando no Estado a "dinâmica do bem e do mal” (p. 3-4). Nas palavras de Machado,

O projeto secular da segurança pública que busca pacificar corpos e almas das populações perigosas converge confortavelmente com o projeto religioso da igreja que busca, ao mesmo tempo, redimir os grupos oprimidos pelas drogas e marcar assim uma posição política no Estado (Machado, 2013: 9).

Assim, entre a conversão imposta pelos agentes religiosos (não só o referido pastor Marcos, mas missionários e pastores de outras denominações) como meio de redenção e a guerra às drogas, os moradores da comunidade patinam entre as fronteiras entre estes dois campos, campo religioso e o chamado campo das políticas públicas, na mesma medida em que a terapêutica vai se conformando, seja pela ausência ou ineficiência de medidas assistenciais reguladas pelo Estado, como a única forma de lidar com essa situação.

Presença pela ausência, é essa a relação que se estabelece neste imbricado de interesses em disputa; diagnóstico muito bem acertado por Machado, quando ela sugere que

convém discutir [...] as consequências específicas da produção das margens do estado através de presenças e ausências de certas políticas públicas nas periferias, ajustando nossa leitura não apenas para a identificação das faltas decorrentes destas ausências, mas os efeitos produtivos e propositivos que surgem na trama social a partir destas, bem como a formação e conformação do religioso e do secular na produção destas margens, a partir da análise de políticas públicas, seus efeitos e articulações (Machado, 2013: 13). 
A boa relação do pastor Marcos com as instituições de segurança pública do estado do Rio de Janeiro, no entanto, dissolveu-se. Ele teve sua prisão preventiva determinada após a acusação de estupro de uma fiel de sua igreja em 2006. Com a denúncia, uma série de outras acusações começaram a surgir, desde ligações com o tráfico de drogas, sexo em troca de "salvação" com as fiéis de sua igreja, abuso de menores e assassinato ${ }^{8}$. Foi solto na véspera do natal de 2014, após a justiça ter acolhido o seu pedido de habeas corpus, e aguarda o desenrolar das investigações das outras acusações.

Outro trabalho que articula as fronteiras e interposições, neste mesmo sentido de Machado é o da antropóloga Patrícia Birman, não obstante o fato de que ela insere na discussão a relação entre o religioso e o secular como dimensões que alteram a cartografia das relações sociais neste contexto. Nessa "reconfiguração do espaço público”, fruto da cada vez mais crescente participação de agentes religiosos em contextos antes apartados dessa esfera, resultaria "entrelaçamentos" nas causas relacionadas "à política, ao pluralismo religioso e a emergência de demandas identitárias” (Birman, 2012: 209).

Para Birman, tais entrelaçamentos colocariam em xeque a visão predominantemente difundida entre os sociólogos, para os quais o "conceito de modernidade associado à secularização foi conceitualmente instituído como um pilar fundador". Secularização, para Birman, é menos aquilo que "Weber, em sua sociologia, constatou, mais do que pensou”, qual seja, "o retraimento da religião na razão direta do avanço da modernização capitalista” (Pierucci, 1998: 45), e mais uma ideologia, "um projeto"; secularismo, como subscreve a autora, conferindo pelo sufixo a característica de uma ideologia (Birman, 2012: 210).

O projeto secularista, para a antropóloga, embaçaria a visão de quem, imbuído dessa missão ideológica, se atrevesse a analisar as redes de entrelaçamento da forma como ela faz neste texto. A “consolidação pentecostal na esfera pública”, uma vez que

http://veja.abril.com.br/noticia/brasil/pastor-marcos-pereira-e-acusado-de-estuprar-menores-e-dematar-uma-delas. Acesso em 14 de maio de 2015. 
altera em definitivo o "quadro de alianças entre instituições” que têm nas periferias o seu locus de atuação, renovaria as formas de gestão das violências nas cidades, especialmente no caso carioca e nas periferias. Aquilo que o sociólogo de Heidelberg “dá de barato”, que permeia todo o seu trabalho e sua ciência, apesar das escassas menções feitas nestes termos, secularização, 'processo de secularização', para ser mais exato (Pierucci, 2008), aparece em questão pelo fato de que, no agora, nessa época não tão mais secularizada, agentes religiosos se colocam pari passu com profissionais e gestores de políticas públicas no combate à violência, participando não só do debate, como também integrando os dispositivos de gestão (Birman, 2012: 211).

É na experiência pioneira da ONG Instituo Brasileiro de Análises Sociais e Econômicas (IBASE), na figura do seu fundador e sociólogo Herbert de Souza, o Betinho, que Birman identifica a origem da demanda por reconhecimento das Organizações Não Governamentais (ONG) e dos movimentos religiosos como "atores capazes de oferecer um diferencial positivo no tratamento da questão da violência na cidade” (Birman, 2012: 213). À época, em meados da década de 1990, com a segurança pública em crise e os após a Chacina da Candelária ${ }^{9}$, estava em discussão a extrapolação completa por parte das policias do uso da força física no combate ao crime, num esforço conjunto de repensar modelos de policiamento e de controle externo das organizações de manutenção da ordem. No projeto de “evitar as mortes, diminuir a letalidade desses conflitos” se envolveram, aponta a autora, agentes religiosos e seculares, bem como os agentes do estado (Birman, 2012: 213).

Como exemplo desse envolvimento misto, do religioso com o secular, a autora cita o Abraço da Candelária, em 1993, ação simbólica onde estudantes, líderes de movimentos sociais, de ONGs e religiosos. Para a autora, o ato marcaria a abertura de “novos horizontes de atuação política”, já que haveria nesse simbolismo uma intenção de prover "alimento espiritual” para os envolvidos, direta ou indiretamente, no conflito (Birman, 2012: 213). A ONG Viva Rio, que cresceria em importância durante

$9 \quad$ Episódio em que oito jovens (sendo seis menores de idade) foram sumariamente executados, entre tantos outros que ficaram feridos, quando dormiam nas proximidades da Igreja da Candelária, no Rio de Janeiro. Para uma análise dos fatos, ver Ferraz e Fernandes (2005). 
as duas décadas seguintes, teria nascido na efervescência deste acontecimento, e organizado o movimento Basta! Eu quero Paz!, nos anos 2000. Segundo Birman, nesta ocasião,

as religiões foram chamadas a participar de projetos primordialmente como atores para conter a escalada desta guerra na medida que dispunham de uma linguagem específica cujos efeitos se distinguem daquela secular (Birman, 2012: 214).

No entender da autora, tal linguagem religiosa "teria como função 'cimentar' a sociedade, fortalecer a sua unidade a complementaridade de suas diferentes 'partes'”, tomando de empréstimo uma visão durkheimiana do fato religioso. Ao diferenciar essas duas linguagens (aquela do Estado, secular, da realpolitk; daquela religiosa), os religiosos passaram a assumir um papel de "congraçamento para a superação das tragédias passadas” (Birman, 2012: 214). Ao clivar estes dois domínios, afirma Birman que

a sociedade secular precisaria recorrer à religião para conter a violência que alguns de seus setores não cessavam de produzir, por um lado e, por outro, para construir formas de congraçamento que reforçassem os elos que uniram seus integrantes entre si (Birman, 2012: 214).

Ao acionar cada vez mais o religioso como dispositivo de gestão, os evangélicos, especialmente os pentecostais, teriam crescido em legitimidade e passaram a ocupar espaços antes pertencentes à Igreja Católica, que viu sua hegemonia ameaçada nas comunidades. Como resultado, as duas religiões majoritárias passaram a disputar espaço e influência naquelas comunidades, em um processo ainda em curso que, segundo a autora, resultara na "fragmentação das demandas religiosas juntamente com novas alianças político-religiosas entre católicos e evangélicos para garantirem conquistas e privilégios nas margens do estado" (Birman, 2012: 215). Ao acionar o discurso do campo religioso numa tentativa de amalgamar as relações sociais estilhaçadas pela violência, agentes seculares teriam reconfigurado de fora a dinâmica do campo religioso nas periferias, trazendo novas agendas, disputas e tensões entre os segmentos religiosos. 
A visão de Birman é interessante, mas deixa lacunas. Em primeiro lugar, a noção de paz, na experiência das UPP, por exemplo (pensando aqui na trilha da autora, como política de segurança pública que busca articular diversas dimensões do social, inclusive a religiosa), não deve ser tomada assim, de barato. As UPPs são, na verdade, mais do que 'cimento' do social, a efetivação de uma cultura policial excessivamente militarizada, que restringe em muito as liberdades e a amplidão das possibilidades de trânsito social nas comunidades, e em grande medida não são vistas com bons olhos pelos próprios moradores.

Há ainda trabalhos interessantes que articulam a dupla pertença identitária de sujeitos que atuam no complexo jogo das políticas públicas de segurança. Trata-se das pesquisas empreendidas pela socióloga Mariana Côrtes (2007) e pela antropóloga Christina Vital da Cunha (2008, 2009a, 2009b, 2014). Côrtes mapeou e investigou a fundo o pujante mercado de testemunhos de "sujeitos antes envolvidos com as práticas do 'mundo do crime' que, ao 'aceitarem Jesus' e tornarem-se 'crentes', também adotaram uma nova carreira: a de pregador” (Côrtes, 2007: 12). Sintoma da atuação cada vez mais efetiva das igrejas pentecostais e neopentecostais nas periferias e nos bairros com alto índice de violência, esses pregadores comercializam no centro de São Paulo suas fitas K-7, CDs e DVDs com as gravações de histórias, em cujo teor enfatizam sempre o contraste da vida anterior (drogas, crimes cometidos, jogos, doenças) com a vida atual (limpa e em comunhão, salvo, regenerado).

Côrtes mostra que a figura do Diabo assume um papel essencial nessas narrativas, em que a vivência anterior é sempre narrada como resultado do seu contato e de sua pertença ao domínio do mal, do diabólico. As religiões afro-brasileiras aparecem frequentemente como as grandes sintetizadoras dessa pertença anterior, uma vez que no discurso desses pregadores, pentecostalizados em seu âmago, o contato com essas religiões é narrado muitas vezes como a porta de entrada para esse terreno do maligno.

Se Côrtes investiga a ruptura de uma pertença identitária vinculada essencialmente ao mal, ao errado, Vital da Cunha toma como objeto de sua pesquisa as bricolagens, como ela mesmo define, dessas pertenças. Ao analisar a realidade 
social do Complexo do Acari, a pesquisadora aborda, entre outras coisas, a emergência de traficantes evangélicos, também como fruto dos projetos de evangelização das comunidades periféricas no Rio de Janeiro. O trabalho em si é riquíssimo: Vital da Cunha se esforça e é muito bem-sucedida em desvendar a imbricada rede de relacionamentos que envolve proteção, delação e fofoca, atuação de líderes religiosos e UPPs, entre outras coisas.

Mas é em relação aos traficantes evangélicos que sua pesquisa foi pioneira em apontar um fenômeno incipiente, que ganharia repercussão em alguns poucos anos: a perseguição dos traficantes evangélicos aos adeptos das religiões afro-brasileiras. Se em um contexto anterior, os líderes religiosos, especialmente os católicos carismáticos, exerciam um papel de intermediação entre os traficantes e o Estado, com o intenso proselitismo, em particular aquele realizado pela Igreja Universal do Reino de Deus (IURD), esses traficantes incorporam o discurso pentecostal e da teologia da prosperidade, assumindo e regulando a dinâmica do “mundo do crime” a partir dessa nova pertença.

As primeiras ações desses traficantes, agora sob a tutela do Espírito Santo, segundo narra Vital da Cunha, foi a iconoclastia em relação aos símbolos que remetiam ao candomblé. Os muros e outdoors, lugares de comunicação e transmissão de signos nas favelas, foram pintados com versículos bíblicos, onde antes havia referência aos orixás. Passaram a patrocinar shows de música gospel, e a incentivar a inserção de obreiros e missionários nas suas redes de relação. Não tardaria para que essa nova realidade recaísse em perseguição: a imprensa, em 2013, já noticiaria que traficantes estava proibindo o uso de roupas brancas, e expulsando pais e mães-desanto das comunidades. As próprias UPPs estariam sendo acionadas para intermediar estas ocorrências ${ }^{10}$.

Mas são dois os trabalhos que tratam exclusivamente de policiais militares e religião, numa análise também focada na relação dessas identidades sobrepostas.

10 Ver reportagem publicada no Jornal O Globo, do dia 10/09/2013, cujo título é “Crime e preconceito: mães e filhos de santo são expulsos de favelas por traficantes evangélicos”. 
Trata-se dos trabalhos antropológicos de Clara Mafra e Robson de Paula (2002), e de Elizabeth Albernaz (2009, 2010). Mafra e De Paula investigaram as concepções de ‘corpo' e 'pessoa' entre os policiais pentecostais cariocas. Os autores perceberam, de forma pioneira, que uma das estratégias de assimilação do ideário pentecostal à profissão de policial seria a inserção discursiva da 'batalha espiritual' como categoria explicativa de suas posições. Atrelados à uma característica marcante do discurso pentecostal, que segue “repondo o dualismo do bem e do mal por onde quer que vá”, e nesse sentido acaba por "dividir o mundo em dois, sem meio termo" (Mafra; De Paula, 2002: 61), tais policiais interpretariam o contexto de violência em que vivem, em constante confronto com bandidos e traficantes, como uma luta moral, contra o mal maior que é representado pelo Diabo. Assim, trata-se do pentecostalismo como agente de encantamento da vida cotidiana e profissional destes indivíduos.

Mas os autores propõem uma interpretação diferente dessa relação. A adesão aos autores ao pentecostalismo representaria, mais do que uma mudança semântica na interpretação de suas realidades, uma mudança nas próprias redes de interação e de relação: dentro da corporação (entre os policiais evangélicos, entre eles e os nãoevangélicos) e fora (nas suas relações com a sociedade). Mafra e De Paula perceberam que, a despeito da sobreposição das identidades, o pertencimento religioso não seria capaz de transpor o ordenamento militar. Resumem muito bem os autores:

Os policiais militares evangélicos distribuem-se nas redes de sociabilidade e profissionais mais amplas, e tendem a não se estabelecer como coletivo orgânico, como 'nós', em nenhum momento no cotidiano do trabalho. No entanto, [...] comungam posturas pessoais e profissionais muito similares (Mafra; De Paula, 2002: 63)

A antropóloga e o antropólogo narram as experiências dos policiais onde, segundo eles, essas posturas pessoais e profissionais se apresentariam como aspecto de diferenciação dos policiais pentecostais para com os outros. Em um caso, os autores abordam o depoimento em que um policial narra as estratégias que utilizou para conseguir que uma pessoa em situação de rua fosse atendida por um hospital cujos atendentes recusavam-se a realizar o atendimento. O policial afirma ter chamado a 
imprensa para intimidar a equipe de recepção com a espetacularização do fato, o que acabou surtindo efeito, e a pessoa foi, enfim, atendida. Em outro caso, um sargento narra como conseguiu impedir um jovem de cometer suicídio, agarrado à linha do trem. O policial afirma ter repreendido os demônios que segundo ele estariam influenciando o jovem e, quando finalmente terminou o ritual de exorcismo, o jovem se levantou, desorientado e chorando.

Entre as posturas pessoais, os autores organizam quatro pontos principais em que, segundo eles, os policiais militares não-evangélicos se difeririam dos pentecostais: na relação com a autoridade, mais rebelde ou ambígua; na concepção masculinista de amizade, que orbitaria necessariamente no consumo de bebidas alcoólicas e na frequentação de bares; na forma como tratariam as mulheres, geralmente de forma "viril e masculinizada”; e no atendimento ao próprio público, empobrecido de sensibilidade e empatia (Mafra; De Paula, 2002: 63).

A despeito do cuidado metodológico dos autores, é necessário ressaltar que a construção desses marcadores de diferenciação é unilateral, construída sob a ótica dos policiais evangélicos. Mesmo assim, e tendo isso em vista, os autores parecem valorizar em demasia o discurso desses policiais na construção de sua argumentação. Isso fica evidente quando, ao sistematizarem os dados da pesquisa, afirmam que "por mais que as situações variem, os fatos mudem, as políticas institucionais oscilem, [os policiais pentecostais] orientam-se por uma noção pacificada de pessoa”, donde poder-se-ia afirmar que estes policiais agiriam como "agentes civilizadores” dentro da corporação. (Mafra; De Paula, 2002: 73).

O trabalho de Albernaz (2009), por sua vez, é uma etnografia de fôlego na Polícia Militar do Estado do Rio de Janeiro (PMERJ). Trazendo uma análise da constituição de um campo evangélico no interior do campo religioso brasileiro, e abordando também o histórico institucional da própria PMERJ, a autora mostra de que forma a União dos Evangélicos da Polícia Militar do Estado do Rio de Janeiro (UEPMERJ) é criada em 1975, consolidando e atuando até hoje na corporação carioca - instituição que se organiza de forma muito semelhante àquela que viria a ser a organização dos PMs de Cristo em São Paulo. 
Albernaz analisa a religiosidade dos policiais cariocas mobilizando três categorias: espaço público, ética profissional e moral religiosa, relacionando-as às diferentes significações que cada uma destas esferas assumiria para os policiais evangélicos religiosamente organizados, para usar um termo da autora. Para tanto, a autora narra as trajetórias de santificação destes policiais, em que buscam uma identidade profissional diferenciada dos não-evangélicos: menos voltada para o trabalho ostensivo, mais em conformidade com os preceitos legais.

Em relação a essas questões, Albernaz não referenda tudo o que ouve destes policiais evangélicos, preferindo apontar possíveis variáveis que, juntamente com a pertença religiosa, poderiam interferir nessas posições. Mas esse discurso, na verdade, se invertido, demonstra que a suposta superioridade profissional dos evangélicos permite dizer que os casos de violência policial, abuso, tráfico de influências, milícias, toda uma série de delitos praticadas e identificadas na corporação carioca seriam praticados pelos não-evangélicos ou não-cristãos. É complicado imaginar que o domínio das ruas seja algo exclusivamente ou majoritariamente não-evangélico.

A chave para essa questão, que Albernaz infelizmente não explora, está no seu capítulo dedicado aos policiais evangélicos do Batalhão de Operações Especiais (BOPE), os Caveiras de Cristo, como chamou numa reportagem uma jornalista que cobriu um culto no batalhão juntamente com a pesquisadora, Toda a função de justificativa da vida cotidiana que as religiões possuem estão lá, escancaradas, quando esses policiais do BOPE interpretam a questão de matar - o BOPE é conhecido como um dos esquadrões de elite que mais matam no mundo - como decorrência da autoridade, que é legal ao mesmo tempo que abençoada por Deus.

Há um problema em considerar esses policiais militares evangélicos como diferentes partindo das informações fornecidas a partir de locais de fala religiosamente interessados, ou ainda traçar correlações baseadas mais em senso-comum do que evidências empíricas ${ }^{11}$. É preciso inverter os sinais dessa equação se quisermos

11 Em um interessante artigo em que analisam a vitimização de policiais militares e civis, os sociólogos Marcelo Ottoni Durante e Almir Oliveira Junior, por exemplo, descobriram que policiais militares não-religiosos eram mais baleados que policias militares religiosos. Na polícia civil, no entanto, a situação seria a inversa, e isso só para ficar em uma das variáveis que analisam. No entanto, os 
compreender a questão em toda a sua complexidade. Por exemplo, como tirar conclusões sobre esses fatos e ao mesmo tempo considerar figuras como o Coronel Telhada, sujeito que, orgulhoso das trinta e cinco mortes em serviço que carrega em seu currículo, vem de uma formação e uma atuação bastante comprometida com a Congregação Cristã do Brasil? Ou ainda as afinidades eletivas entre a bandada da bala e a bancada evangélica ${ }^{12}$, que na confluência de seus membros votam em conjunto a favor de pautas como redução da maioridade penal, liberalização do porte de armas, etc.? Ainda podem ser chamados de agentes civilizadores nestes contextos?

E em relação às redes de interação estudadas por Birman e Machado, por exemplo. Como explicar a tripla atuação do Pastor Marcos que, ao que tudo indica, atuava como líder religioso, mediador em questões de segurança pública e facilitador das relações do 'mundo do crime’? Ou a crescente perda de reconhecimento, enquanto interlocutores legítimos, de ONGs como o AfroReggae junto às populações e aos movimentos sociais organizados das comunidades, e cujo arsenal discursivo em nome da paz era incrementado simbolicamente pela aproximação com artistas e líderes religiosos. É necessário analisar o local de fala de onde emana a concepção de paz e justiça, que parece ser na maioria das vezes olhado de cima para baixo.

Ao analisar essas experiências do policial militar enquanto religioso, principalmente os evangélicos, falta ainda uma análise complexa das consequências desse trabalho duplamente interessado, enquanto policial militar e enquanto agente da manutenção da ordem. Uma delas, poderíamos pensar, é que este passaria a agir, concomitantemente, como um impositor de regras e valores morais, para além dos

pesquisadores afirmam ser possível "supor [...] que os policiai sem religião e menos educados seriam mais vitimados em função dos seus estilos de vida” (Durante; Oliveira Junior, 2013: 135). A suposição é arriscada, a meu ver. São tantas religiões, tantas variáveis interligadas, tanta falta de informações sobre a religião nas policiais, que qualquer afirmação baseada em suposição é bem difícil de ser feita.

12 Frentes parlamentares pluripartidárias compostas por líderes religiosos e funcionários ou exfuncionários da segurança pública, principalmente policiais do alto escalão. A comunicadora social Magali Cunha do Nascimento traz uma análise dessa confluência, em um observatório de religião e política mantém, no endereço: http://midiareligiaopolitica.blogspot.com.br/2015/04/evangelicos-ereducao-da-maioridade.html. O jornal O Estado de S. Paulo traz uma análise do apoio da bancada BBB, "bala, boi e bíblia", donde se soma aos grupos os ruralistas, também com interesses conservadores, ao presidente da Câmara dos Deputados Eduardo Cunha, do PMDB-DF: http://politica.estadao.com.br/noticias/geral,cunha-impoe-pauta-turbinado-por-bbbs,1676227.

Acesso em 16 de agosto de 2015. 
prescritos pela sua profissão. Isso, nas palavras de Becker (2008), representaria o papel de uma cruzada moral. Segundo o autor,

o protótipo do criador de regras [...] é o reformador cruzado. Ele está interessado no conteúdo das regras. As existentes não o satisfazem porque há algum mal que o perturba profundamente. Ele julga que nada pode estar certo no mundo até que se façam regras para corrigi-lo. Opera com uma ética absoluta; o que se vê é total e verdadeiramente mal sem nenhuma qualificação. Qualquer meio é válido para extirpá-lo. O cruzado é fervoroso e probo, muitas vezes hipócrita (Becker, 2008: 153).

O que quero dizer, através da definição de Becker, é que o policial principalmente o religioso - não atuaria simplesmente como agente a serviço de alguma agenda específica: ele acreditaria piamente que o seu dever é reestabelecer a sanidade do corpo social através do resgate de determinados valores. Quando apreende o portador de drogas ilícitas, não o faz simplesmente baseado em suas atribuições; ele realmente crê que esse sujeito é nocivo e merece ser retirado do convívio. Temos aí um duplo empreendedorismo moral, profissional e religioso; pela lei e pela ordem, contra o pecado e pelo reino de Deus. Aqui, temos uma espécie de ponto cego do trabalho policial, onde convicção religiosa (e, portanto, moral) se mistura à sua atribuição definida por lei (ainda que de forma imprecisa). Ainda segundo o autor,

Cruzados morais querem, de modo típico, ajudar os que estão abaixo deles a alcançar um melhor status. Outra questão é saber se o s que estão abaixo deles gostam sempre dos meios propostos para sua salvação. Mas esse fato - que as cruzadas morais são em geral dominadas por aqueles situados nos níveis superiores da estrutura social - significa que eles acrescentam ao poder que extraem da sua legitimidade de sua posição moral o poder que extraem de sua posição superior na sociedade (Becker, 2008: 154-155).

Claro que Becker está falando aqui da aplicação e da defesa de regras, e não de leis. As primeiras são criadas no interior das instituições e da sociedade, a partir da sua própria dinâmica e funcionamento, ao contrário dessa última, colocadas a partir da constituição e da legislação. Mesmo assim o paralelo é possível. No entanto, a consequência de uma cruzada moral bem-sucedida é justamente a criação de uma série 
de mecanismos e dispositivos que garantam sua imposição (p. 161). Para os policiais evangélicos com os quais mantive contato, a melhor saída para os desvios morais era justamente a proibição destes atos através da lei.

Analisando dessa forma, caberia perguntar: o que muda, exatamente, se um policial age de determinado modo por convicção ou por crença? Essa pergunta pode ser respondida em dois tempos. Primeiro, uma cruzada moral baseada nos valores subjetivos de um policial tende a depreciar determinadas atitudes que não são necessariamente erradas, mas moralmente questionáveis (dependendo, é claro, do repertório valorativo em que cada indivíduo se ampara), mas que definem diretamente a postura e atuação destes profissionais. Não se trata mais de ser crime ou não, de ser proibido ou permitido pela lei; trata-se de ser certo ou errado.

A segunda dimensão dessa questão é mais complicada, mas também facilmente observável. Não é possível generalizar para toda a corporação, mas, em todas as ocasiões onde tive a oportunidade de esboçar um diálogo sobre a relação entre criminalidade e exclusão, nenhum policial fez qualquer alusão a um processo sistemático de eliminação de uma parcela indesejada da população através do aumento vertiginoso das taxas de encarceramento ou das execuções e mortes em confrontos com a polícia (e não era de se esperar que esse diálogo frutificasse). Porém, em vários momentos, ouvi destes policiais um discurso onde imoralidade, miséria e crime se relacionavam de forma estranhamente concatenada, onde a imoralidade era ao mesmo tempo causa e consequência da suposta ruína da sociedade. Trata-se de restaurar a sociedade retirando aquilo que a corrói por dentro, ou seja, a imoralidade e os comportamentos impuros.

Assim, mais do que uma suposta missão civilizatória - voltada tanto para dentro da corporação, quanto para a sociedade a qual esse profissional jurou "proteger e prevenir” - a atuação religiosamente orientada dos policiais consegue, no máximo, ressignificar o seu universo, atribuir outros valores à sua worldview, diria Geertz (2008). Não há mudança efetiva nos padrões de policiamento, na cultura policial ou que viria de um suposto ethos pacifista cristão, nem nas funções desempenhadas pelos policiais - que Albernaz (2009) teve a sensibilidade de perceber que se trata de uma 
falsa impressão, essa que supõe que cristãos pacíficos assumem papéis burocráticos, enquanto caberia aos outros (não-pacíficos? violentos?) o papel de policiamento ostensivo.

Além disso, como explicar, por esse prisma, outras religiões que atuam dentro e fora da corporação policial, ligados diretamente ou não com instituições de segurança pública em geral - e também influenciariam, hipoteticamente, as conduções dessas políticas, sem partilharem deste suposto ideal pacifista cristão? É nesse sentido que proponho a abordagem, levando em conta a configuração destas diferentes denominações em relação, configurando uma situação particular do campo religioso, utilizando a Polícia Militar como objeto de análise.

\section{A presente pesquisa: objetivos e procedimentos}

Convém agora, finalmente, explicitar os objetivos dessa pesquisa. Se atentarmos para as questões colocadas acima, é possível perceber que há um deslocamento falseador - seja nas pesquisas de cunho acadêmico, seja na forma como aparece na imprensa - das relações que resultam dos influxos dos fenômenos religiosos na área da segurança pública. Especificamente em relação à literatura acadêmica, fica evidente que o foco por demais aproximado das relações microssociólogicas dos agentes nessa estrutura acabam por camuflar o jogo de forças que ocorre na competição destes mesmos agentes nas posições que ocupam.

Por isso, o que proponho é analisar, tomando como objeto de pesquisa a Polícia Militar do Estado de São Paulo, a inserção, o desenvolvimento, a atuação e a expansão dos religiosos e grupos religiosos a partir de suas estratégias próprias de desenvolvimento. Trata-se de analisar, em um primeiro momento, as relações religiosas que ocorrem a partir do reconhecimento, em maior ou menor grau, que diferentes associações religiosas galgam junto ao comando policial da corporação paulista, para, posteriormente, analisar a dimensão relacional destes indivíduos uns com os outros e com a sociedade em geral. É, resumindo, trazer um jogo de escalas 
que considere as diferentes formas de regulação dos diversos grupos que atuam na corporação. Sim, diversos grupos. Talvez o maior achado desta pesquisa tenha sido a possibilidade de identificar, na polícia paulista, quatro grupos distintos que competem pelo mesmo espaço.

Foi em minha pesquisa de iniciação científica, realizada anteriormente com o auxílio da FAPESP ${ }^{13}$, que identifiquei quatro associações ou grupos religiosos organizados dentro da estrutura da PMESP. São eles: os PMs de Cristo, de caráter evangélico; os PMs a Caminho da Luz, de orientação espírita kardecista; os PMs de Axé, adeptos de religiões afro-brasileiras; e a Capelania Católica da PMESP. Cada um desses grupos organiza atividades, promove eventos e reuniões e participa ativamente do cotidiano dos policiais militares, seja na fase de formação de novos policiais nas academias ou no trabalho de rua dos policiais militares.

É da relação destes quatro grupos entre si, e deles com o comando, que tracei a minha estratégia de pesquisa, que teve por finalidade investigar e compreender a dinâmica religiosa dentro da PMESP, sua forma de distribuição e atuação, bem como a interface das visões religiosas dentro das corporações. As perguntas que pretendi fazer não se resumiriam - e nem se resumem mais - a fornecer pistas sobre supostas incompatibilidades entre profissão policial e éticas supostamente pacifistas e religiosamente orientadas, mas sim esclarecer em alguma medida quais as condições de permanência destes grupos em uma sociedade que cada vez mais prescinde da assistência religiosa como terapêutica?

No que tange o levantamento bibliográfico, tomei por base a literatura acadêmica sobre a instituição policial militar e adesão, conversão e esfera religiosa, religião e espaço público e laicidade estatal. Meu foco recaiu de forma mais precisa sobre os autores que se debruçaram sobre esses assuntos tendo como base a realidade social brasileira. Também pesquisei diários virtuais de policiais militares, publicações editoriais que vinculam religião, criminalidade e policiamento e folhetos e informes

13 Pesquisa intitulada "Entre fé e vocação: religiosidade e profissão no cotidiano do policial militar”. Processo FAPESP 2011/06268-0. 
religiosos que circulam dentro da corporação, além de páginas da imprensa oficial e documentos públicos arquivados na Biblioteca Municipal Mário de Andrade.

Em relação à pesquisa de campo, busquei, a partir dos contatos previamente estabelecidos na pesquisa de iniciação científica acima mencionada, bem como de novas redes que se estabeleceram desde então, me aproximar das lideranças ou dirigentes de cada um dos grupos elencados como objeto de nossa pesquisa, a saber: os PMs de Cristo, os PMs a caminho da Luz, os PMs de Axé e a Capelania Católica.

Através de entrevistas, diálogos e experiências vividas em conjunto com essas lideranças, busquei traçar, em um primeiro momento, a organização institucional desses grupos. Em todo o momento da pesquisa de campo, na construção do problema e na análise dos dados apontados, utilizei como embasamento metodológico a proposta de uma sociologia da configuração social conforme elaborada por Norbert Elias.

Tal metodologia pressupõe o rompimento com definições das categorias de indivíduo e sociedade como antagônicas, na medida em que abandona a ideia de que “a sociedade é constituída por estruturas que nos são exteriores — os indivíduos —e que os indivíduos são simultaneamente rodeados pela sociedade e separados dela por uma barreira invisível” (Elias, 2008: 15).

Na esteira desse tipo de análise, o que nos importa de forma mais precisa é analisar as cadeias e redes de interdependência que se entrelaçam entre os indivíduos pertencentes a um determinado grupo, e deste grupo com outros, e do grupo para os seus indivíduos. Segundo Elias,

só podemos compreender muitos aspectos do comportamento ou das ações das pessoas individuais se começarmos pelo estudo do tipo da sua interdependência, da estrutura das suas sociedades, em resumo, das configurações que formam uns com os outros (Elias, 2008: 79).

Assim, tal metodologia se ajusta melhor à pesquisa aqui proposta. Ainda que nosso foco seja o policial militar e sua dimensão religiosa, importa aquilo o que isso acarreta de social. O objeto são os policiais, mas a análise foca nas redes de 
interpenetração dos policiais. De outra forma, segundo Elias, não seria possível. Ele se pergunta:

como é possível chegar à conclusão de que os indivíduos, devido à sua interdependência e ao modo como as suas ações e experiências se interpenetram, formem um tipo de configuração, uma espécie de ordem relativamente autônoma do tipo de ordem dominante, se, tal como os biólogos ou os psicólogos, estudamos os indivíduos quer como representativos da sua espécie quer como pessoas isoladas? (Elias, 2008:79).

Levando em conta que "o tipo especial de ordem associado aos processos de interpenetração social é melhor considerado se começarmos pelas conexões, pelas relações, e trabalharmos a partir delas para os elementos nelas envolvidos” (Elias, 2008: 126), nossa pesquisa pretende lançar luz sobre a dimensão religiosa da corporação policial militar, a partir da análise da interpenetração das relações profissionais e religiosamente orientadas.

Assim, estruturei essa dissertação em três capítulos.

No Capítulo 1 busco analisar, primeiramente, a estrutura da polícia militar enquanto instituição, inspirado nas teses weberianas sobre o Estado moderno enquanto depositário inegociável do monopólio e da distribuição da força física em um território, para, em seguida, complementar essa interpretação com autores que propõe uma teoria da ação policial. Na esteira dessas teorias, o que se propõe é compreender a função e o papel das polícias nas sociedades modernas a partir de seus agentes, onde os valores morais e interações sociais destes últimos é que definiriam a sua estruturação. A partir dessa inversão, analiso as formas e os modelos pelos quais se estruturam as polícias militares brasileiras, em especial a corporação paulista. A partir das hierarquizações oriundas principalmente das formas diferenciadas de ingresso na carreira policial, busco explicar em que medida a organização da estrutura policial favorece a criação de dois tipos de instituições religiosas na PMESP: os grêmios e os grupos religiosos.

No Capítulo 2, apresento cada um dos grupos e atores religiosos que se estruturam dentro da corporação paulista, não sem antes traçar os antecedentes 
históricos que influenciaram e influenciam essas estruturações. Procuro mostrar de que forma as diversas formas de cooperação entre o Estado brasileiro e a Santa Sé romana instituíram e elegeram a religião católica, através do seu serviço de capelania, como instituição privilegiada, única reconhecida formalmente e com status oficial frente às forças armadas e ao Estado.

A partir da análise do caso paulista, procuro ainda traçar o processo pelo qual essa religiosidade oficial perde força na medida exata em que a Igreja Católica retrai em sua capacidade de persuasão e de fazer valer seus interesses, momento em que outros atores religiosos, percebendo o declínio da tradicional instituição romana, passam a disputar esse espaço. Argumento que há uma relação direta entre a perda de influência e posterior declínio católico e a efervescência e pluralização religiosa na PMESP, principalmente com a entrada dos evangélicos na disputa por reconhecimento e legitimidade. Além dos evangélicos, também abordo a trajetória dos espíritas e dos afro-brasileiros nessa celeuma, onde cada qual busca desenvolver suas estratégias e, da mesma forma que os evangélicos (ou contra os evangélicos, no caso dos afro-brasileiros), constituir-se como atores legítimos neste meio.

No Capítulo 3 procuro analisar sociologicamente a dinâmica e a convivência destes grupos, nas suas relações entre eles, com o comando e com a sociedade, na medida em que propõem, particularmente os evangélicos, uma reinterpretação da profissão e da missão policial a partir de suas teologias. Se na análise histórica analisei as configurações do religioso na PMESP partindo de uma embocadura mais ampla, tomando como base as noções de interpenetração e interdependência do sociólogo alemão Norbert Elias, neste capítulo busquei (sem medo de cometer qualquer ecletismo teórico, dada a confluência das teorias sociais) remontar esse cenário a partir da noção de Pierre Bourdieu de campo, buscando identificar as disputas entre os atores que constituem o que poderia ser chamado de campo religioso militarizado (ou militarmente organizado), a partir das posições que ocupam e das suas interpretações, que propõem diferentes formas de justificativa para a realidade social a qual são submetidos estes profissionais. 
Finalmente, em Conclusão, retomo os principais achados e interpretações que puderam ser alcançados na presente investigação. 


\section{CAPÍtulo 1:}

\section{A POLÍCIA MILITAR E OS GRUPOS RELIGIOSOS}

\section{Da corporação militar ao policial sujeito da ação social: uma análise sociológica}

Na definição clássica de Weber, o Estado pode ser definido a partir de uma característica que lhe é específica, qual seja, a de que este reivindica para si o monopólio do exercício da coação física. Ainda que determinadas instituições exerçam atividades relacionadas ao uso da força física, somente o fazem na medida em que o Estado as autoriza. Em suas próprias palavras, “o Estado é aquela comunidade humana que, dentro de determinado território [...] reclama para si (com êxito) o monopólio da coação física legítima” (Weber, 2009: 525).

Importa, aqui, tratar do quadro burocrático de funcionalismo estatal que é organizado e orientado diretamente para o exercício da coação física dentro de determinado território: no Brasil, estamos nos referindo às polícias. Essa categoria de profissionais, depositárias do recurso último de poder de vida e morte sobre os cidadãos, constituem, assim como outros funcionários do aparelho burocrático de estado, o instrumento de domínio efetivo do Estado. Nas palavras do próprio Weber,

em um Estado moderno, o domínio efetivo, que não se manifesta nos discursos parlamentares nem em declarações de monarcas, mas sim no cotidiano da administração, encontra-se, necessária e inevitavelmente, nas mãos do funcionalismo, tanto do militar quanto do civil (Weber, 2009: 529). 
Alguns autores propõem a formulação de uma teoria dessas instituições; uma teoria policial. Bittner (2003), por exemplo, trabalha com uma ideia análoga a de Weber ao propor tal teorização. Em sua análise, assim como na teoria do Estado moderno de Weber, o que define o trabalho policial não é o simples fato de que este utilize o recurso à força, mas sim a noção de que, por trás de toda uma gama de atribuições, há a possibilidade da utilização da coerção física para cumpri-las. Segundo o autor,

o papel da polícia é enfrentar todos os tipos de problema humanos quando (e na medida em que) suas soluções tenham a possibilidade de exigir (ou fazer) uso da força no momento em que estejam ocorrendo. Isso empresta homogeneidade a procedimentos tão diversos como capturar um criminoso, levar o prefeito para o aeroporto, tirar uma pessoa bêbada de dentro de um bar, direcionar o trânsito, controlar a multidão, cuidar de crianças perdidas, administrar os primeiros socorros médicos e separar brigas de familiares (Bittner, 2003: 136).

Ou seja, mais do que o emprego da força física, as instituições policiais se encarregam de uma gama quase infindável de atribuições, mesmo que, oficialmente, tais atribuições não estejam protocoladas ou claramente pré-definidas. Nessa visão, não se trata apenas de manutenção da ordem, da resposta ao chamado e do controle dos crimes. Tais atribuições, por si só, não caracterizam o trabalho policial em toda a sua extensão. O que confere unidade ao trabalho policial é o fato de, por trás de todas essas funções executadas, por trás de sua atribuição de aparelho regulador e vigilante, está a possibilidade de recorrer, em última instância, conforme as necessidades, ao uso da força. Nas palavras de Bittner,

o papel da polícia é melhor entendido como um mecanismo de distribuição de força coerciva não negociável empregada de acordo com os preceitos de uma compreensão intuitiva das exigências da situação (Bittner, 2003: 138).

Assim, o autor afirma ainda que o "policial, e apenas o policial, está equipado, autorizado e é necessário para lidar com toda emergência em que possa ser usada força para enfrentá-la” (p. 240). A tal afirmação, Bittner propõe que sejam colocadas algumas observações. Uma delas, o autor coloca da seguinte forma: "Não estou 
dizendo que o trabalho policial consiste no uso da força para resolver problemas, mas apenas que o trabalho policial consiste em lidar com problemas em que a força pode ter de ser utilizada” (p. 241, grifos do autor). Nessa lógica, a tarefa de lidar com o crime e com os criminosos passa a figurar como consequência dessa especificidade do trabalho policial, não como finalidade ou objetivo primeiro deste. Bittner identifica uma inversão nas percepções sobre o trabalho policial, quando afirma que

\begin{abstract}
A concepção do papel da polícia [...] está de cabeça para baixo. O que acontece não é que os policiais sejam autorizados a utilizar a força porque devem lidar com criminosos sórdidos. Mas ao contrário, o dever de lidar com criminosos sórdidos recai sobre eles porque eles têm a autoridade mais geral de utilizar a força quando necessário para conseguir os objetivos desejados (Bittner, 2003: 241, grifos do autor).
\end{abstract}

David Bayley (2006) retoma essa noção de polícia utilizada por Bittner. Em sua definição, polícia se refere a "pessoas autorizadas por um grupo para regular as relações interpessoais dentro deste grupo através da aplicação da força física” (2006, p. 20). Tal categorização baseia-se em três elementos essenciais: “força física, uso interno e autorização coletiva” (idem: 20). Também como Bittner, Bayley considera que o que realmente define polícia não é o uso real e efetivo da força, mas sim sua autorização para utilizá-la conforme as circunstâncias, ou, em outras palavras, “mesmo quando não usam de força, ela está por trás de toda interação que acontece” (Shearing; Leon, 1975 apud Bayley, 2006: 20).

Bayley (2006) esquematiza um sistema baseado nessas definições para delinear uma classificação geral de instituição policial, bem como para caracterizar o tipo de policiamento predominante no mundo moderno. Assim, a polícia se caracteriza por utilizar a força física no âmbito interno - em oposição aos exércitos, por exemplo, que atuam no âmbito externo - da comunidade. Tal utilização deve ser autorizada por essa comunidade (em oposição aos levantes, crimes e revoltas, que não são autorizados ou legitimados pela comunidade) (idem: 26). O caráter público da agência policial, seu foco especializado e sua profissionalização constituiriam, segundo Bayley, as características principais do policiamento moderno. 
Por agência pública, Bayley caracteriza aquelas cuja autorização da comunidade para o uso efetivo da força física tem natureza estatizada, ressaltando que tal fato não significa que não existam agências privadas com reconhecimento da comunidade como legítimas. Em relação à especialização, o autor afirma que “o policiamento se torna especializado quando as agências são direcionadas a se concentrar principalmente na aplicação de força física” (Bayley, 2006: 25). Por fim, por profissionalização, Bayley se refere às características da organização, da administração, dos planos de carreira e do treinamento oferecido, que visam à formulação de técnicas e modelos voltados para o aumento da eficácia e do desempenho dessas agências.

No caso do Brasil, as atividades policiais são realizadas, no âmbito estadual, pela polícia civil e militar ${ }^{14}$, as quais são reguladas através da Constituição Federal e pelas Constituições Estaduais. Segundo Neme, “a polícia civil exerce funções de polícia judiciária e apuração das infrações penais, exceto as militares, e à polícia militar cabem o policiamento ostensivo e a preservação da ordem pública” (1999, p. 21). Devido a esse caráter ostensivo, o foco dessa pesquisa incide diretamente sobre a polícia militar, uma vez que sua atuação profissional possui um caráter de vinculação e relacionamento diretos e cotidianos com o restante da sociedade.

A Polícia Militar do Estado de São Paulo (PMESP) conta, atualmente, com um efetivo de 85.056 profissionais ${ }^{15}$. Destes, 79.201 policiais são alocados em atividades operacionais, correspondentes ao policiamento ostensivo, efetivamente na rua; são as chamadas atividades-fim. Trata-se de uma instituição organizada militarmente, que encontra na figura do governador do estado o seu "Chefe Supremo"16, e que atua nas seguintes áreas: Polícia de Trânsito, Polícia Ostensiva, Programa de Policiamento

\footnotetext{
14 No nível federal, esse serviço cabe à Polícia Federal e à Polícia Rodoviária Federal.

15 Os dados obtidos sobre efetivo e distribuição das funções da PMESP foram retirados de: Pesquisa perfil das instituições de segurança pública. - Brasília: Ministério da Justiça, Secretaria Nacional de Segurança Pública (SENASP), 2013.

16 De acordo com o Artigo $3^{\circ}$ da Lei Complementar $N^{\circ}$ 893, de 09 de março de 2001: "Hierarquia policial-militar é a ordenação progressiva da autoridade, em graus diferentes, da qual decorre a obediência, dentro da estrutura da Polícia Militar, culminando no Governador do Estado, Chefe Supremo da Polícia Militar”.
} 
Escolar, Programa de Policiamento Integrado, Programa de Forças Táticas, Programa de Policiamento Comunitário, Programa de Radiopatrulha - Atendimento "190" e Programa ROCAM. Assim, de acordo com essa divisão, as patrulhas ou guarnições são destacadas e organizadas de diferentes modos, de acordo com cada área de atuação ${ }^{17}$.

Enquanto corporação, a polícia militar se apresenta como a linha de frente do processo de garantia da ordem, uma vez que assume o papel de depuração da sociedade de seus “elementos nocivos” através do uso da força. Incumbidos de certa concepção de assepsia social da população, é atribuído às polícias o papel de identificar e remover qualquer elemento que represente perigo à continuidade do status quo. Tais elementos correspondem, não raramente, às classes menos favorecidas e economicamente inferiores. Neme (1999: p. 31) afirma que "estudos que analisam a polícia como instrumento de poder caracterizam a força policial como um elemento essencial de controle das classes populares”.

A violência dentro da atividade cotidiana profissional do policial militar, no entanto, não é uma via de mão única; também o policial é, pela própria natureza de sua atuação, vítima de ações violentas. Segundo Albernaz, "No exercício de seu ofício poderoso, esses agentes enfrentam ameaças constantes, em que frações de segundos podem encenar escolhas - dramáticas e nem sempre conciliáveis - entre vida e morte” (2010: p. 525). Ainda que a tarefa de lidar com tais situações limites seja atribuída à polícia enquanto corporação, são indivíduos que a colocam em prática, sobre cuja subjetividade pouco ou nada se conhece. Segundo Skolnick e Bayley,

todos os estudiosos do policiamento consideram que o modo particular como o policial enxerga o mundo ao seu redor e seu papel dentro dele é uma chave indispensável para a compreensão do comportamento e das atitudes da polícia (Skolnick; Bayley, 2006: 71).

É possível concordar com os autores quando se analisa o fazer policial de uma ótica exclusivamente centrada na corporação. De fato, a cultura policial que estrutura

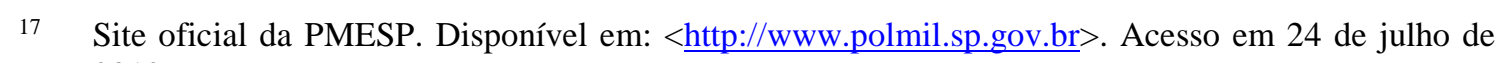
2012. 
nossas polícias é lida de forma invertida, de acordo com os interesses e disputas em jogo. Mas essa característica criativa não é tão efetiva quando alimentada a partir de outras esferas da vida social, ou outros campos de poder. É nesse sentido que inserção do religioso na polícia está vinculado à forma pela qual a corporação se estrutura, conforme iremos analisar no próximo ponto.

\section{As escolas de formação de policiais militares de São Paulo: o sistema de dupla-entrada e a formação dos grêmios religiosos}

A inserção na organização policial militar funciona através do sistema conhecido como dupla-entrada. No nível dos praças, os aprovados ingressam no Curso Superior de Técnico de Polícia Ostensiva e Preservação da Ordem Pública, que se divide em três níveis (para soldados, cabos e sargentos, podendo chegar até a patente de subtenente). Para a carreira de oficial, o indivíduo candidata-se a uma vaga do curso de nível de bacharel, realizado na Academia de Polícia Militar, e cujo ingresso se dá através, geralmente, de processo vestibular. O aluno formado como bacharel garante a posição de Aspirante a Oficial PM e, depois de passar por um estágio probatório que varia entre oito e dez meses, assume o posto de $2^{\circ}$ Tenente. Caso queira, o oficial pode se candidatar ao Curso de Formação de Oficiais Superiores, que equivaleria à pós-graduação. Só assim poderá chegar ao posto de Major, Tenentecoronel e Coronel.

Assim, no caso da polícia paulista, o sistema hierárquico exige que da patente de soldado até a chegar a coronel - os dois extremos da hierarquia - seja necessário cursar três estágios de formação: o curso na Escola Superior de Soldados (ESSd), em Pirituba; a Escola Superior de Sargentos (ESSgt), no Tatuapé; e a Academia de Polícia Militar do Barro Branco (APMBB), no Tucuruvi, essa responsável por formar os oficiais da PMESP. São nessas escolas e na academia que se localiza a gênese dos grupos religiosos que investigo nessa pesquisa: os grêmios, nos quais incluem-se os religiosos. 
As escolas de formação e a academia de polícia militar organizam os grêmios de modo a oferecer atividades complementares à formação de policial militar. São divididos em grêmios Desportivos, Técnico-policiais, de Responsabilidade Social e Religiosos. Os Técnicos-policiais (tiro, bombeiro, cavalaria, operações especiais) 'encaminham' os alunos para as áreas que irão atuar depois de formado, e a participação em um ou mais grêmios é parte obrigatória do conteúdo programático da formação, caso também dos Desportivos. O grêmio de Responsabilidade Social e os Religiosos, por sua vez, são ofertados em caráter voluntário. Para todos, funciona a seguinte hierarquia organizacional: um aluno do último ano é eleito presidente do grêmio, e responde diretamente ao oficial designado como supervisor. Quando este conclui a sua formação, assume um novo aluno do último ano. Segundo os últimos dados do Anuário do Fórum Brasileiro de Segurança Pública, havia, em 2012, 196 alunos na Academia de Polícia Militar do Barro Branco, e outros 2659 em formação nas Escolas de Sargentos e de Soldados ${ }^{18}$.

São três os grêmios religiosos: o Católico, Espírita e Evangélico. Criados nas dependências da Academia de Polícia Militar do Barro Branco na década de 80, e replicado nas escolas de Soldados e de Sargentos, seus membros se fazem representar em praticamente todas as cerimônias oficiais: recepção dos ingressantes, formaturas, comemorações de datas festivas, feriados de celebrações patrióticas, etc. O grêmio católico, criado em 1980, foi peça fundamental no fortalecimento das relações da capelania militar católica com a corporação paulista. Em suas reuniões semanais, leem a bíblia, rezam o terço e entoam cânticos, como qualquer grupo de jovens no Catecismo.

18 Disponível em $<$ http://www.forumseguranca.org.br/produtos/anuario-brasileiro-de-segurancapublica/8o-anuario-brasileiro-de-seguranca-publica>. Acesso em 15 de abril de 2015. 


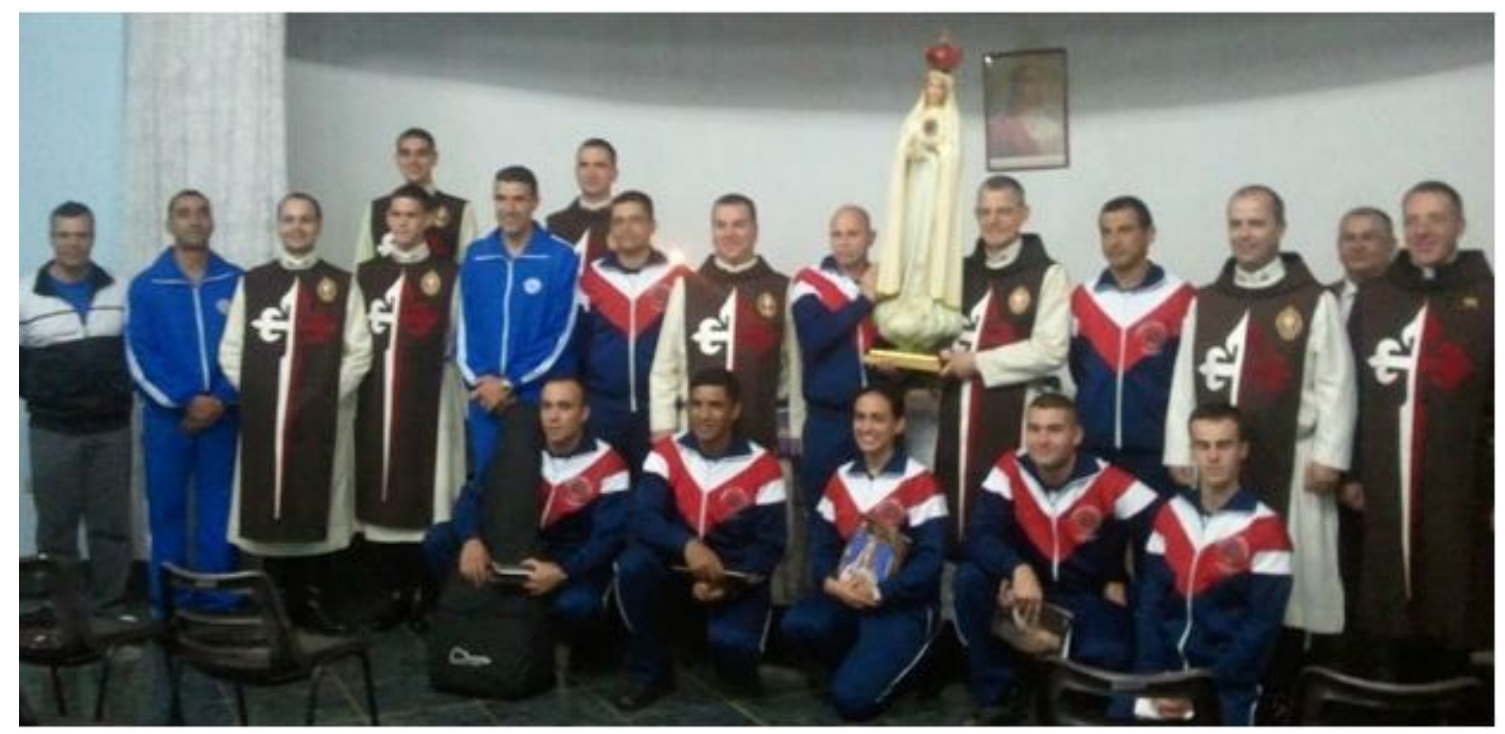

Imagem 01 - Reunião do grêmio católico da APMBB

(Fonte: Acervo PMESP)

O grêmio evangélico, por sua vez, seria o ponto de ligação e a via de institucionalização dos PMs de Cristo na PMESP, na sua versão 'oficial'. Criado em 1984, é o mais numeroso em número de participantes, chegando a reunir mais de 50 alunos em algumas reuniões, e reúne-se semanalmente para a leitura da bíblia e para oração, apresentando em seu discurso a função de "promover apoio espiritual a todos que necessitem”. Definem-se como um grupo interdenominacional, a despeito da presença maciça de pentecostais na sua composição

Já o grêmio espírita é o mais recente. De vertente kardecista, sua criação data do final da década de 90, e foi o embrião do projeto de constituição de uma associação de policiais espíritas, os PMs a Caminho da Luz, projeto que não chegou a ser completamente oficializado, mas segue atuante. 


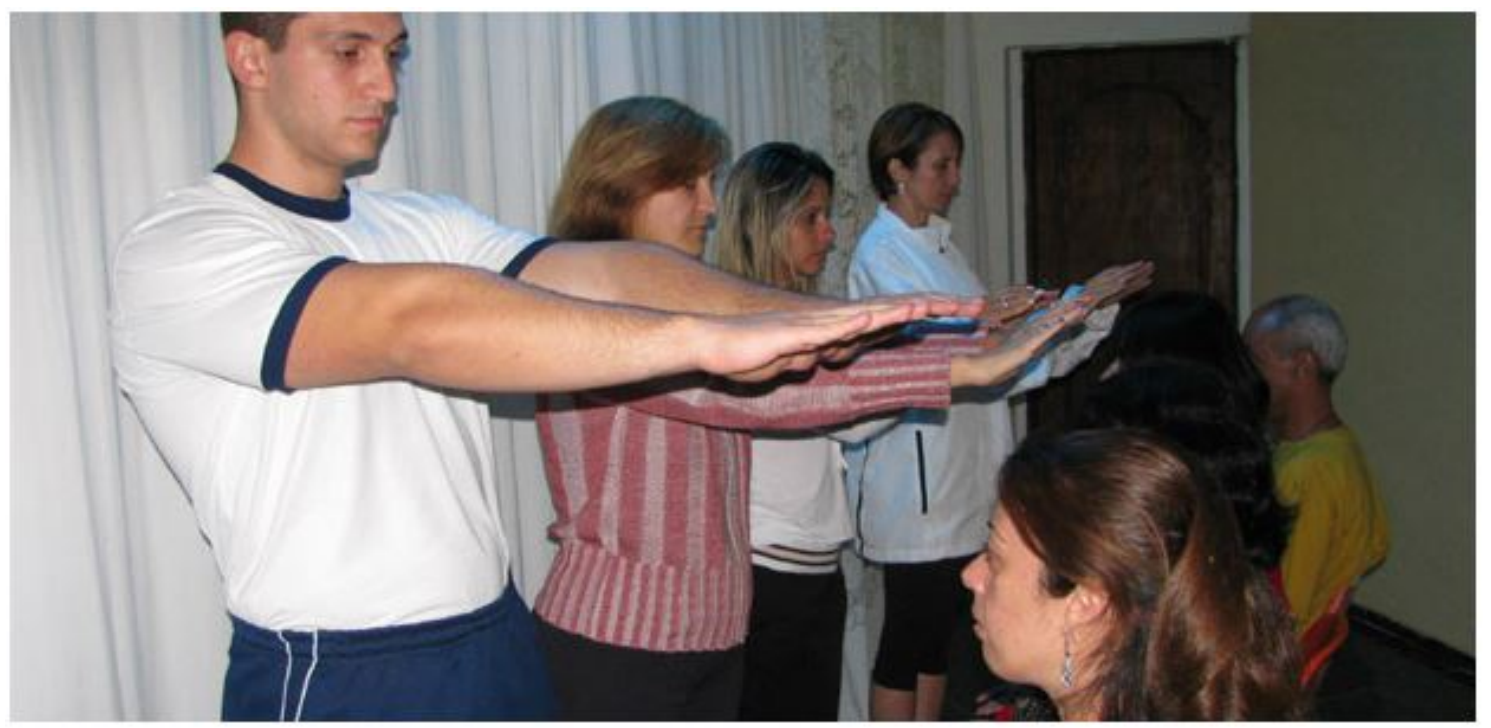

Imagem 02 - Reunião do grêmio espírita na APMBB. No primeiro plano, um alunooficial ministrando o passe.

(Fonte: Acervo do Grêmio Espírita)

Se os grêmios são os embriões das associações religiosas que atuam na PMESP, no caso dos evangélicos e espíritas, ou elo de ligação, no caso dos católicos, suas atuações mobilizam aspectos jurídicos distintos dos das associações e da capelania. Quem primeiro chamou a atenção para este fato foi Pedro Simões, antropólogo e pesquisador do Instituto de Estudos da Religião (ISER). Na pesquisa sobre assistência espiritual no sistema socioeducativo que coordenou, Simões aponta a distinção legal que fornece legitimidade para um e outro tipo de prestação de assistência religiosa. No caso das unidades de internação de adolescentes que pesquisou, e que vale aqui para os grêmios, o que se reivindica é o direito à “assistência religiosa nas entidades civis e militares de internação coletiva”, previsto no artigo $5^{\circ}$ da Constituição Federal. Religião como direito, organizada de motu próprio pelos próprios alunos das escolas e da academia que, com a circulação restrita devido ao regime de internato, buscam garantir suas formas de expressão religiosa.

A vinculação ao imperativo do direito à assistência religiosa de que trata Simões é bem diferente daquela que norteia a noção de capelania militar, que se aproxima da forma de atuação dos grupos e associações. Segundo o antropólogo,

a finalidade da capelania é diferente da assistência religiosa, a saber: prestar assistência religiosa e espiritual aos militares, aos civis das organizações militares e às suas famílias, bem como atender a encargos 
relacionados com as atividades de educação moral realizadas nas Forças Armadas. Portanto, ela não é restrita àqueles que se encontram internados (Simões, 2010: 29).

Este ponto é importante para a análise que seguiremos adiante. Quando falamos dos grêmios, estamos falando de uma estrutura que é montada de modo a permitir que os alunos recebam a assistência e manifestem suas concepções religiosas do modo que bem entenderem. Já com as associações, o que se busca é o reconhecimento legal enquanto instituição que presta um serviço de interesse público dentro da corporação, mobilizando in totum os preceitos do inciso I do artigo 19 da Constituição Federal, que afirma:

Art. 19. É vedado à União, aos Estados, ao Distrito Federal e aos Municípios:

I - estabelecer cultos religiosos ou igrejas, subvencioná-los, embaraçarlhes o funcionamento ou manter com eles ou seus representantes relações de dependência ou aliança, ressalvada, na forma da lei, a colaboração de interesse público.

Interesse público e a vedação ao embaraçamento de seu funcionamento: eis os fundamentos dos grupos que passarei a analisar. 


\section{Capítulo 2:}

\section{OS RELIGIOSOS ORGANIZADOS NA PMESP}

\section{Os grupos organizados}

Apresento agora os grupos religiosos que atuam na PMESP, não, sem antes, tecer algumas considerações metodológicas. Primeiramente, coloquei como critério para a escolha dos grupos um fato objetivo: que estes, em algum momento, tenham angariado o reconhecimento formal por parte da corporação policial. Não desconsidero a existência de outros grupos de caráter religioso que se reúnem na PMESP, seja nas suas escolas de formação, seja nos seus batalhões e companhias, e tampouco considero irrelevante a eventual existência de confissões de fé solitárias e individuais dos seus policiais.

A escolha por uma análise da inserção e estruturação desses grupos religiosos pressupõe a busca pelo reconhecimento formal e exige, a meu ver, uma ponderação sobre as relações de força, tensão ou aceitação envolvidas neste processo. Nesse sentido, faço um esforço sociológico de interpretar essa realidade a partir de processos em curso em uma escala macrossociológica. Assim, busco demonstrar que a religiosidade institucionalizada da PMESP se vincula diretamente às configurações políticas das relações entre Igreja Católica e esfera pública, bem como ao modelo adotado pelas religiões protestantes de atuação nesse quadro. Da mesma forma, argumento que a implementação de novos modelos e sistemas de gestão, impulsionados pelas crises de legitimidade da PMESP ou pelas mentalidades de 
policiamento colocadas em curso, exerce influência direta na configuração da religião na corporação.

Trata-se, nas palavras de Norbert Elias, de considerar a configuração de “sistemas dentro de sistemas e processos dentro de processos”, interpenetráveis entre si, em sua capacidade de regular o próprio curso de outros sistemas menores - em escala, diga-se - que por sua vez constituem a configuração dos pertencimentos, atividades e participação dos indivíduos nestes grupos. Segundo o sociólogo alemão, é a estrutura e o desenvolvimento de determinado sistema maior que

em última instância, determina os de seus sistemas parciais, incluindo aqueles de seus membros individuais. Diferentes níveis dessa hierarquia de sistemas, tanto enquanto indivíduos como enquanto famílias ou classes, têm maior ou menor grau de autonomia; podem, por exemplo, cooperar uns com os outros ou podem lutar entre si. O limite das ações autônomas varia, entretanto, com as propriedades do sistema predominante, bem como com o posicionamento das unidades parciais dentro dele; e o mesmo acontece com a estrutura básica de personalidade de seus membros individuais (Elias, 1998: 147).

Assim, somente graças ao equilíbrio mais ou menos estável das configurações e interdependências desses sistemas que é possível que esses grupos religiosos atuem com relativa liberdade dentro da PMESP. É neste sentido que proponho uma forma de análise alternativa aos estudos realizados, até agora, sobre policiais religiosos ${ }^{19}$. Não intento isolar ou explorar uma suposta incompatibilidade entre éticas religiosas e doutrina policial - como se uma propusesse o amor e a paz e a outra a guerra e a violência. Analisar dessa forma seria incorrer ou numa visão demasiadamente antropológica, afetada em excesso pela noção de estranhamento; ou na armadilha de não penetrar a malha discursiva que recobre a realidade social dessas configurações.

Pensando nisso, elaborei estratégias diferenciadas para colher e sistematizar as informações que aqui apresento. Em relação aos católicos, procurei, inicialmente, levantar, tendo em conta a relação direta de suas instituições com o poder público, as formas de regulação desta relação. Tomo emprestada a noção a partir da concepção

19 Refiro-me aos trabalhos de Albernaz (2009; 2010) e Mafra e De Paula (2002), comentados no primeiro capítulo. 
dada por Giumbelli (2002). O antropólogo, ao analisar o modelo francês e o brasileiro de relação estatal com o religioso, abandona a noção de separação enquanto referencial analítico, cuja utilização acarretaria, segundo ele, na "imposição à realidade de um modelo que jamais se realizou historicamente”, bem como na presunção da possibilidade “de um grau zero de regulação estatal da religião” (Giumbelli, 2002: 50).

Giumbelli utiliza, no lugar, uma análise das regulações, termo que o autor associa à noção weberiana de que “ vivemos em sociedades que concebem o mundo como algo repartido em esferas, entre as quais figura a 'religiosa', e que precisam elaborar formas de administrar essas repartições”. Essas formas de administração ou regulação - seriam definidas por “representações, instituições práticas”, mais ou menos mutáveis historicamente (Giumbelli, 2002: 51-52). Diminuindo um pouco a embocadura do conceito proposto por Giumbelli, analiso o serviço de capelania militar católica em dois tempos: primeiramente, em um nível mais amplo, a partir dos marcos regulatórios diretamente relacionados a ela; posteriormente, mais focado na PMESP, no movimento decorrente de sua relação com a corporação policial paulista.

Em relação aos PMs de Cristo, fiz o esforço de me desvencilhar da narrativa institucional do grupo. Minhas experiências de pesquisa junto ao grupo recaiam cada vez mais frequentemente em uma noção valorativa e apologética de seus membros, o que obnubilava o olhar sociológico sobre o grupo. Frente a isso, optei por me afastar analiticamente, reconstruindo a trajetória da conformação de um projeto evangélico de policiamento a uma concepção militarizada de evangelização. Por fim, com os PMs de Axé, inverti a situação: a ingerência civil na formulação e estruturação do grupo e o histórico de tensões em relação ao comando da corporação aflorou a dimensão combativa do grupo. Percebi que expor as condições que motivaram tais tensões através da minha pesquisa constituiria, principalmente por parte de seu mentor religioso, parte dessa estratégia de combate. Ao mesmo tempo, minhas buscas de outros pontos de vista sobre os acontecimentos recaíram em nada, em um curioso fenômeno de invisibilização do grupo. Nessas condições, resolvi assumir os riscos. 


\section{Os católicos e o serviço de capelania militar}

Como a assistência espiritual aos soldados, por causa das condições particulares de vida que levam, exige grande cuidado, erija-se sendo possível, um vicariato castrense em cada nação. Tanto o Vigário como os capelães dediquem-se com zelo a este difícil apostolado, de acordo com os Bispos diocesanos (Decreto Christus Dominus do Concílio Vaticano II, de 28 de outubro de 1965)

Dentre as denominações religiosas legalmente instituídas e oficialmente reconhecidas na PMESP, a igreja católica é, sem dúvida, a pioneiríssima: vem antes da própria formatação da corporação como polícia militar - resultado da unificação da Força Pública do Estado de São Paulo e da Guarda Civil ${ }^{20}$. O serviço de capelania militar, que tinha como foco inicialmente as forças armadas, foi e continua sendo regido por decretos e pactos entre o Estado brasileiro e o Santa Sé, além da regulação pela própria Constituição Federal (CF). A criação das polícias militares estaduais, espelhadas na organização do exército, demandou das mesmas formas de regulação, contendo em suas respectivas legislações estaduais os parâmetros regulatórios da assistência religiosa nas polícias.

Ainda que sejam abundantes, os estudos sobre capelania militar que apresentam uma reconstituição histórica detalhada (Cachone, 2006; Almeida, 2006; Crivelari, 2010; Mello, 2013) são resultados de trabalhos de cursos superiores em teologia e ciências da religião, quando não de cursos de aperfeiçoamento das academias, realizados pelos próprios agentes. Não obstante, o tom predominante desses trabalhos é marcadamente circunscrito às noções de “importância",

20 O marco que utilizamos aqui é o Decreto-lei 217, de 1970, que unificou a forças policiais e organizouas militarmente, criando a Polícia Militar do Estado de São Paulo. Seria ingênuo da minha parte, porém, se eu não considerasse que o processo de unificação está umbilicalmente ligado a um processo histórico mais abrangente de mudanças na configuração da sociedade brasileira como, por exemplo, o acentuado processo de urbanização que perpassava o período. Várias pesquisas importantes acerca desse processo foram e têm sido realizadas. Indico o pioneiro trabalho de Fernandes (1979) para uma compreensão histórica e sociológica desse processo, bem como o trabalho de Neme (1999) e a ótima pesquisa de Bueno (2012) sobre o papel da PMESP em um contexto de ordem democrática. Do ponto de vista histórico, há o trabalho de fôlego de Rosemberg (2010), que analisa a instituição policial no período da república velha. O trabalho de Pedroso (2005), que enfoca a gênese da mentalidade militar na Força Pública do Estado de São Paulo, traz uma bibliografia extensa e sistematizada sobre as polícias brasileiras. 
“relevância” e “papel fundamental” para designar o trabalho dos capelães. Busquei não me ater, no momento, ao caráter apologético destes trabalhos, levando em conta o levantamento historiográfico neles contido apenas como baliza.

Parece consenso, nesses estudos, que o marco regulatório inicial do serviço de capelania militar é o Decreto n. ${ }^{\circ}$ 747, de 24 de dezembro de 1850, ainda no período imperial. O decreto, além de regras para a e vestimenta dos capelães e os critérios de subordinação hierárquica, trazia no seu artigo $9^{\circ}$ as funções da então chamada Repartição Eclesiástica do Exército:

Art. $9^{\circ}$ Os Capellães Miltares são considerados como verdadeiros Parochos dos Corpos em que servem, e seus deveres principaes são: dizer Missa ás Tropas, confessa-las, dirigi-las em todos os actos religiosos, bem como nos principios da boa moral, convencendo-as sobretudo com o seu exemplo; acudir com os soccorros da Religião aos enfermos e moribundos, encommendar, e acompanhar os mortos a seus jazigos, sem que por taes actos recebão estipendio algum.

Com a estreia republicana e a dissolução da união Estado-Igreja Católica, e resultado da influência positivista e, consequentemente, do anticlericalismo no meio militar (Piovezan, 2011: 4), omitiu-se, na Constituição de 1891, a menção ao serviço de assistência religiosa nas corporações militares, situação que perduraria até a promulgação da Constituição de 1934. Essa, no sexto parágrafo do Artigo n. ${ }^{\circ}$ 113, previa que

6) Sempre que solicitada, será permitida a assistência religiosa nas expedições militares, nos hospitais, nas penitenciárias e em outros estabelecimentos oficiais, sem ônus para os cofres públicos, nem constrangimento ou coação dos assistidos. Nas expedições militares a assistência religiosa só poderá ser exercida por sacerdotes brasileiros natos.

Eis que foi, então, solicitada. Através do Decreto-Lei n. ${ }^{\circ}$ 6.535, de 26 de maio de 1944, assinado pelo então presidente Getúlio Vargas, criou-se o Serviço de Assistência Religiosa (SAR) ao Exército em tempos de guerra - na ocasião, tendo em vista a assistência religiosa à Força Expedicionária Brasileira (FEB) nos combates em terras italianas. Fruto, preponderantemente, da decaída da influência positivista e do 
arrefecimento do anticlericalismo no meio militar; somada a um período de bons relacionamentos entre o clero e governo de Vargas (Della Cava, 1975; Mariano, 2001), o decreto-lei reestabelecia o privilégio católico perdido com o fim do regime de padroado. A justificativa estaria na a relação de causalidade estabelecida entre educação moral e cívica e assistência religiosa, de onde derivaria a relevância do serviço. Note, na Constituição de 1934, a restrição feita ao financiamento do serviço com recurso público: ela seria solenemente ignorada na redação do decreto, já que este determinava em seu artigo n. ${ }^{\circ} 4$ que "os membros do S.A.R. serão nomeados por portaria do Ministro da Guerra e farão jus, para sua manutenção pessoal, a uma côngrua correspondente aos vencimentos e vantagens atribuídos ao pôsto de $1^{\circ}$ Tenente”. $\mathrm{O}$ artigo n. ${ }^{\circ} 3$, por seu lado, determinava que o efetivo de capelães fosse composto por sacerdotes ou ministros "pertencentes à Igreja Católica, aos cultos adotados pela Religião Protestante, ou a qualquer outra religião”, com a conhecida condição de que estas últimas não ofendam a "disciplina, a moral e as leis”. Foram enviados 25 capelães católicos e dois protestantes, um Batista e um Metodista (Piovesan, 2013: 5).

A existência da SAR seria assegurada em caráter permanente pelo DecretoLei n. ${ }^{\circ}$ 8.921, de 26 de janeiro de 1946. Mantendo a relação causal entre moralidade, religiosidade e disciplina militar no seu preâmbulo, e considerando "que o Serviço de Assistência Religiosa junto à Força Expedicionária Brasileira cumpriu suas altas finalidades”, o texto do decreto colocava como única condição que o candidato ao posto fosse brasileiro nato. Matinha, no seu artigo $3^{\circ}$, a possibilidade de que a função de capelão militar pudesse ser exercida por representantes de qualquer religião, desde que esta "não atente contra a disciplina, a moral e as leis". Curiosamente, colocava no mesmo artigo a necessidade de que a religião do postulante ao cargo fosse professada, “no mínimo, por um terço dos efetivos das unidades a serem contempladas”. Curioso, mas não inócuo: em um período em que mais de 95\% da população brasileira se 
declarava católica, o artigo literalmente barrou a atuação de capelães de outras confissões $^{21}$.

A Constituição de 1967 extinguiu o trecho que vetava o "ônus aos cofres públicos” da constituição anterior, e estendeu o direito à assistência religiosa às forças auxiliares (Artigo n. ${ }^{0}$ 153, parágrafo 7). A Lei Federal n. ${ }^{\circ}$ 5.711, de 08 de outubro de 1971, por sua vez, foi a primeira a assegurar, de fato, a possibilidade de ingresso como capelão aos sacerdotes de outras religiões que não a católica romana: consta no seu artigo n. ${ }^{\circ} 4$ que o SAR ficaria a “cargo de sacerdotes, ministros religiosos ou pastores”, distribuídos entre as forças na ordem de 20 oficiais na Marinha, 25 no Exército e 20 na Aeronáutica. A legislação não faz qualquer menção à quantidade de fiéis enquanto parâmetro para o preenchimento destas vagas, deixando a cargo do comando de cada uma das forças determinar a divisão do quadro de capelães, de acordo com "as representações correspondentes aos diversos credos” (Artigo n. ${ }^{\circ}$ 7).

Tal lei seria revogada pela Lei $n^{\circ}$ 6.923, de 29 de junho 1981. Essa estruturaria e organizaria o SAR na mesma formatação apresentada atualmente, mantendo a divisão da capelania entre as diferentes armas e número determinado de capelães por força, mas diminuindo o efetivo de capelães. Inseriria ainda, de modo definitivo, a noção de "proporcionalidade" como parâmetro para a distribuição dos oficiais capelães entre as diversas religiões (Artigo n. ${ }^{0}$ 10). Ao mesmo tempo, traria no seu artigo n. ${ }^{\circ} 18$ novos requisitos para o ingresso do postulante: a formação, em nível universitário, em Teologia (parágrafo IV); e o exercício comprovado de ao menos três anos de atividades pastorais (parágrafo $\mathrm{V}$ )

Na ocasião da convocação da Assembleia Constituinte de 1988, as regulações preexistentes foram incorporadas ao texto final da carta, sendo que essa traz nos parágrafos VI, VII e VIII do seu Artigo $5^{\circ}$ o que viria a ser a palavra final, no âmbito constitucional, sobre a garantia do serviço de assistência religiosa:

\footnotetext{
21 Dados do Censo de 1940 realizado pelo IBGE. Disponível em: $<$ http://biblioteca.ibge.gov.br/visualizacao/monografias/GEBIS\%20\%20RJ/CD1940/Censo\%20Demografico\%201940\%20VII_Brasil.pdf>. Acesso em 14 de julho de 2014.
} 
VI - é inviolável a liberdade de consciência e de crença, sendo assegurado o livre exercício dos cultos religiosos e garantida, na forma da lei, a proteção aos locais de culto e a suas liturgias;

VII - é assegurada, nos termos da lei, a prestação de assistência religiosa nas entidades civis e militares de internação coletiva;

VIII - ninguém será privado de direitos por motivo de crença religiosa ou de convicção filosófica ou política, salvo se as invocar para eximirse de obrigação legal a todos imposta e recusar-se a cumprir prestação alternativa, fixada em lei. (CF, art. 5, VI-VIII)

Assim, pode-se afirmar que os sucessivos mecanismos regulatórios do SAR obedecem a uma lógica que é própria do nosso Poder Legislativo: as constituições são revistas por outras constituições (ou emendas constitucionais, no caso da Constituição de 1967), o que é óbvio. Ocorre que as leis, decretos-lei e portarias são dispositivos hierarquicamente inferiores às constituições, e visam fornecer as diretrizes e regulamentações administrativas e burocráticas necessárias para o cumprimento das leis constitucionais. Pois bem. O que ocorre é que não houve uma lei específica que legislasse sobre o artigo $5^{\circ}$ da Constituição de 1988. O que houve foi um acordo direto, uma concordata assinada entre o Brasil e a Santa Sé. Trata-se do “Acordo entre a República Federativa do Brasil e a Santa Sé”, que passou a vigorar a partir de 22 de novembro de 1989.

O acordo nada mais é do que a instituição do Ordinariado Militar em solo brasileiro, conforme as diretrizes da constituição apostólica Spirituali Militum Curae, redigida pelo então Papa João Paulo II e publicada em 21 de abril de 1986 (essa, por sua vez, é o cumprimento do decreto Christus Dominus, do Concílio Vaticano II, assinado pelo Papa João VI em 28 de outubro de 1965). Diz a primeira norma dessa constituição:

$\S 1$. Os Ordinariados militares, que podem também chamar-se castrenses e que são juridicamente assimilados às dioceses, são circunscrições eclesiásticas especiais, regidas por estatutos próprios emanados pela Sé Apostólica, nos quais serão precisadas mais em pormenor as prescrições da presente Constituição, mantendo-se válidas, onde existem, as Convenções estipuladas entre a Santa Sé e os Estados [...] 
$\S$ 2. Onde as circunstâncias o aconselhem, ouvidas as Conferências Episcopais interessadas, serão erectos pela Sé Apostólica os novos Ordinariados militares.

Apesar de juridicamente questionável, o acordo tem, lá, a sua razão de ser: desde 1934, todas as Constituições brasileiras, inclusive a atual, asseguraram a possibilidade de a União estabelecer alianças ou "colaborações recíprocas" com instituições religiosas, em nome do "interesse coletivo". Interesse coletivo, essa concepção de difícil mensuração, foi o gancho constitucional que possibilitou o acordo, enquanto que a expressão ““colaboração recíproca” [...] era a senha para que, na prática, se efetivasse e se intensificasse a relação entre Estado e igrejas, sobretudo do Estado com a religião hegemônica” (Mariano, 2001: 149). Em termos concretos, o acordo assinado representou a retomada da primazia católica no SAR - agora em versão turbinada - e foi sinal de entendimento entre o Estado e Igreja Católica, cujas relações chegaram a limites extremos de hostilidade no período de exceção: a despeito da empolgação católica no período brevemente seguinte ao golpe de 64, "a edição do Ato Institucional n. 5, em 1968, e a progressiva repressão de leigos e sacerdotes católicos - prisão, expulsão, tortura e até assassinato de agentes pastorais e padres constituem os acontecimentos determinantes para a deterioração da relação entre os militares e o episcopado católico (Mariano, 2001: 153-154).

Em relação ao acordo Brasil-Santa Sé, Joana Zylbersztajn (2012), analisando do ponto de vista do direito constitucional, dedica especial atenção ao seu Artigo 13, que afirma: “competirá ao Estado-Maior das Forças Armadas, respeitadas as suas limitações, prover os meios materiais, orçamentários e de pessoal necessário ao funcionamento da Cúria do Ordinário Militar”. Interpretando o artigo, a autora, que não se furta em deixar clara a sua posição laicizante, entende que

Ordinariado Militar é uma instituição da Igreja Católica, seguindo sua organização e regras. Nada obstante, é integrado à estrutura organizacional do Ministério da Defesa e sustentado pelo orçamento federal. Há absoluta mistura entre a organização religiosa e estatal (Zylbersztajn, 2012: 181) 
Ela não deixa de ter a sua razão. Analisando friamente, os capelães militares são os únicos sacerdotes no Brasil pagos com dinheiro público em troca de seus préstimos religiosos. Ao passo que o artigo I do acordo determinou a criação do OM com sede na Arquidiocese de Brasília, o artigo III instituiu que o Ordinário Militar “terá a dignidade de Arcebispo e ficará vinculado administrativamente ao Estado Maior das Forças Armadas, sendo nomeado pela Santa Sé, após consulta ao Governo brasileiro" ("vinculado administrativamente" = inserido na folha de pagamentos), o segundo parágrafo do artigo VII prevê que sejam destinados sacerdotes “do clero secular ou religioso” para assistirem o OM. Ou seja, toda uma estrutura eclesial a ser, “conforme as legislações específicas”, lançada dentro da máquina estatal. Economia para a o clero, na melhor das hipóteses.

A carta de entendimento entre o Brasil e a Santa Sé sobre o SAR seria o segundo de três acordos assinados pelas partes até os dias de hoje. O primeiro, de 1935, tratava de assuntos relacionados à troca de correspondências entre os países signatários. O terceiro viria a ser o acordo bilateral entre a República Federativa do Brasil e a Santa Sé relativo ao Estatuto Jurídico da Igreja Católica no Brasil. O acordo, “elaborado de forma sigilosa por representantes e funcionários do governo brasileiro e do Vaticano por dois anos” (Mariano, 2010: 16), foi aprovado em 2009 Câmara dos Deputados, apesar do descontentamento e de acirrada oposição por parte de deputados da oposição, representações de entidades acadêmicas e de lideranças da igreja evangélica. Segundo Mariano,

opositores laicos e religiosos do acordo acusaram-no de constituir um grave retrocesso por ameaçar e ferir a laicidade estatal. A seu ver, ele viola o artigo 19 da Constituição brasileira, que veda ao Estado manter relações de dependência ou aliança com cultos religiosos e igrejas e subvencioná-los, confessionaliza a disciplina de ensino religioso facultativo ministrada em escolas públicas de nível fundamental, contrariando a Lei de Diretrizes e Bases da Educação, e implica a concessão de subvenção estatal à Igreja Católica (em defesa de seu patrimônio cultural, por exemplo) e a privilegia em detrimento das demais agremiações religiosas. Outra discriminação repousou no fato de que nenhum outro grupo religioso dispõe de instrumento jurídico que permita assinar acordo internacional. Em termos gerais, os adversários do acordo denunciaram entraves e riscos diversos que ele representava 
para a laicidade estatal, a democracia, a liberdade, a tolerância e o pluralismo religiosos (Mariano, 2010: 16-17).

Ainda que o debate tenha se demonstrado mais acirrado nas questões relativas ao ensino religioso nas escolas públicas, o acordo chamou a atenção dos adversários para a concordata de 1989. Conferindo estatuto jurídico ao Ordinariado Militar (que até então não possuía), o texto do acordo de 2009 cita a manutenção dos termos já acordados em 1989, o que, colateralmente, acabou expondo-o a questionamentos. Segundo Roseli Fischmann, "uma das mais combativas laicistas do país” (Mariano, 2010: 14) e que participou do processo de tramitação como representante da sociedade civil, o deputado Andre Zacharow (PMDB-PR) chegou a apresentar um requerimento ao Ministério das Relações Exteriores, solicitando esclarecimentos sobre o acordo de 1989. Zacharow afirmou, durante a sessão, ter recorrido à Consultoria Legislativa da Câmara em busca de documentos referentes à tramitação do acordo, não obtendo sucesso. Assim, "apurou que o referido acordo nunca passou pelo Congresso Nacional, como exige a Constituição de 1988, motivo pelo qual não pode ser considerado como estando em vigor”. Seria, portanto, ilegal.

Zacharow apontou ainda que, uma vez ilegal e em pleno funcionamento, demandando "dispêndios financeiros do Estado para sua efetivação", seria possível "instaurar ação popular ou ação civil pública, pois são mais de vinte anos de aplicação de verbas públicas em organismos irregulares, do ponto de vista da ordem jurídica” (Fischmann, 2009: 577-578). Com a aprovação em tempo recorde do acordo de 2009 apesar das críticas e das oposições, convalidou-se o acordo de 1989, fortalecendo a influência do OM e alçando-o, do ponto de vista jurídico, à legalidade. Concomitantemente ao processo de elaboração e tramitação do acordo de 2009, o Ministério da Defesa redefiniu através da Portaria Normativa n. ${ }^{\circ}$ 142, de 25 de outubro de 2008, o regimento interno do OM, fixando em definitivo a sua estrutura e suas atribuições. Além de integrar ao OM os capelães das polícias militares e do corpo de bombeiro, a portaria reforçava a prerrogativa da Santa Sé na escolha, transferência e desligamento dos capelães militares. Segundo o último levantamento da Comissão 
Nacional de Bispos do Brasil (CNBB) realizado em 2004, havia um total de 144 capelães militares católicos subordinados ao OM no Brasil.

Outro marco importante foi a criação da Comissão dos Serviços de Assistência Religiosa das Forças Armadas (COSARFA), através da Portaria No 101/MD, de 17 de janeiro de 2012, assinada pelo atual Ministro da Defesa Celso Amorim. A intenção era que a COSARFA constituísse um espaço deliberativo e representativo das autoridades religiosas, intermediando a relação entre o $\mathrm{OM}$, as forças armadas e auxiliares e o Ministério da Defesa, através de reuniões quadrimestrais realizadas em Brasília. No artigo 17 da portaria, consta que "as despesas de funcionamento da COSARFA correrão por conta do orçamento do Ministério da Defesa, observada a disponibilidade orçamentária e financeira”.

Situada no Bairro da Luz, em São Paulo, a Capela Militar de Santo Expedito foi, até o começo deste ano de 2015, uma das mais movimentadas da cidade. As missas realizadas pelo padre Osvaldo Palópito, tenente-coronel capelão da PMESP, atraíam fiéis de todas as regiões da capital paulista, além de pessoas que migravam do interior do Estado para receber as benções do padre e manifestar sua devoção por Santo Expedito. A capela foi a primeira erguida em nome do santo no Brasil, no ano de 1942, e foi edificada a pedido dos militares que, à época, se concentravam no quartel do comando-geral, nas imediações do bairro. Osvaldo, a que tudo indica, foi o último capelão a constar no Quadro de Oficiais Capelães (QOC) da PMESP.

O QOC se vincula administrativamente ao Centro de Assistência Social (CAS). Criado em 1985 por meio de decreto do então governador Franco Montoro, foi designado inicialmente como Centro de Assistência Social, Jurídica e Religiosa (CASJR) e tinha como atribuições a “administração da Capelania Militar, do Fundo de Auxílio Mútuo, do Centro de Convivência Infantil, orientação jurídica e pensão extrajudicial”. O processo de modernização administrativa e de gestão pelo qual passou a PMESP na década de 90 inseriu, gradativamente, a assistência psicológica como prioridade do CASJR, relegando a assistência religiosa ao segundo plano. Não por acaso, em 1995 o CASJR já contava com um efetivo de 17 psicólogos, frente um único capelão, o padre Júlio Villano. 
Não foi por acaso todo o investimento realizado em assistência psicossocial. A PMESP, em sua história, nunca havia matado, morrido e se suicidado tanto quanto na década de 90 - e nunca havia gozado de tão pouco prestígio. A atuação da tropa de choque da PMESP na Casa de Detenção, em $1992^{22}$, e as imagens veiculadas dos abusos cometidos na Favela Naval, em 1997²3, marcariam em definitivo e negativamente a história da corporação. Ainda, a PMESP matou em 1991 um total de 1.140 pessoas; e em 1992, 1.470, ante uma média histórica que até aquele ano se aproximava de 500 assassinatos por anos. No mesmo período, foram mortos 78 policiais em 1991 e 58 em 1992, número expressivamente acima da média de aproximadamente 35 mortes por ano nos cinco anos anteriores (Bueno, 2014: 23).

Segundo Bueno, “a partir desse momento foi implementada uma série de mudanças institucionais, sob o tripé direitos humanos, gestão pela qualidade e policiamento comunitário, até hoje tido pela PMESP como o símbolo de uma nova corporação, pensada para proteção dos cidadãos” (2014: 53). Ainda, havia o problema com o suicídio, que se tornava endêmico na corporação. Segundo Lima, “o número de suicídios [na] corporação havia aumentado 50\% em 1994 e que era crescente desde 1979, tendo sido considerado excessivo em 1989 (com 19 mortes) e alcançado seu pico em 1992 (com 35 casos)” (2003: 84). Nesse cenário, era arriscado demais confiar na terapêutica religiosa.

Voltando ao serviço de capelania, consta que padre Villano ingressou como capelão-auxiliar em 1973, como assistente do então capelão-chefe, Luis Marques Barbosa. Com a aposentadora de Barbosa ${ }^{24}$ em 1984, Villano presta o concurso para

22 Na ocasião, a tropa de choque da PMESP foi acionada, por ordem do então governador Fleury, para conter uma rebelião na penitenciária. A ação da tropa resultou no assassinato de 111 detentos, encurralados nas suas celas, sem chance de defesa ou de fuga.

23 Durante cinco dias, um cinegrafista amador filmou as operações em busca de drogas dos policiais do 28BPM na Favela Naval. O que se viu, na verdade, foram torturas e extorsões sistemáticas praticadas contra os moradores. Na ocasião, o soldado Otávio Lourenço Gambra, o Rambo, executou, por capricho, um morador. Foi condenado a 47 anos de prisão no presídio Romão Gomes, unidade penitenciária destinada aos policiais que cometem crimes. Rambo era evangélico. <http://veja.abril.com.br/idade/em_dia/favela_capa.html>. Acesso em 10 de agosto de 2014.

24 Com a aposentadoria compulsória da PMESP, o padre Barbosa foi designado a servir na paróquia da cidade de Arapiraca, no Alagoas. Em 2009. aos 83 anos de idade, foi acusado e condenado por pedofilia, após um vídeo em que aparece fazendo sexo com um coroinha ter chegado ao conhecimento da polícia. Além do processo canônico de expulsão, levado a cabo por Bento XVI, foi condenado 21 
capelão-chefe e ingressa como tenente coronel capelão. Frente ao processo de racionalização do atendimento psicológico e emocional em curso no sistema de gestão da PMESP, e com a Capela Militar de Santo Expedito demandando cada vez mais trabalho, os serviços de Villano passaram a se circunscrever cada vez mais aos serviços paroquiais habituais, como a celebração de missas, casamentos e batizados, não obstante, nesses atendimentos, a primazia dos policiais militares - prevista no acordo com a Santa Sé - que disputavam a agenda do padre com os civis ${ }^{25}$. Focava ainda, prioritariamente, na assistência religiosa no Hospital da Polícia Militar (HPM), também nas imediações do Bairro da Luz. Sintomaticamente, em 1999, em um boletim circulado internamente, o Comando Geral da PMESP alterou a denominação do setor de assistência e para Centro de Assistência Social Jurídica (CASJ).

Foi também graças à influência de Villano que se estabeleceu o primeiro grêmio religioso no âmbito da Academia de Polícia do Barro Branco (APMBB). A pedido dos alunos-oficiais, o padre Villano intensificou sua atuação junto ao grêmio. Segundo o site oficial da agremiação, foi solicitado ao padre "que se oferecesse com maior frequência auxílio espiritual aos alunos, contemplando-os com catequeses, atividades de evangelização e também assistência aos sacramentos do Batismo, Crisma, Eucaristia e Penitência (confissão)”. Com a aposentadoria do padre Villano, assumiu a função de capelão o auxiliar de Villano, padre Osvaldo Palópito. Com uma dezena de discos gravados (com o nome artístico de Osvaldo Paló) e bacharel em Direito, Palópito havia prestado o concurso para capelão em 1988, em uma época que, segundo ele, “os bispos não gostavam muito de perder o padre da diocese” para a doutrina militar. Seu modelo de assistência permaneceu basicamente o mesmo de Villano, exceção feita à sua atuação mais incisiva na participação em cerimônias

anos de reclusão. Ver <http://g1.globo.com/brasil/noticia/2011/12/religiosos-sao-condenados-porpedofilia-em-arapiraca-al.html>. Acesso em 25/08/2014.

25 O padre Villano é apontado como o responsável pelo boom devocional a Santo Expedito, em função das novenas e da divulgação do santo no programa do radialista Eli Correa. Considerado o "santo da moda” na cidade de São Paulo, a capela militar, antes exclusiva dos policiais, se via então tomada por civis. Sobre a devoção a Santo Expedito na cidade de São Paulo, ver os trabalhos de Rampazzo (2006) e Moreno (2000). Além de trazerem entrevistas com Eli Correa e com o próprio padre Villano, os trabalhos abordam o processo histórico de edificação da capela militar. 
oficiais da PMESP e na ministração de bênçãos aos ingressantes e aos formandos das escolas de formação, às viaturas adquiridas, etc.

Em janeiro deste ano, Paló, a pedido, foi transferido para a reserva da polícia militar. Acusado de desviar cerca de dois milhões de reais do caixa da capelania, o agora ex-padre e ex-militar é alvo de uma investigação que corre em segredo de justiça. A revista Isto É de 27/02/15, em reportagem cujo título é “Ladrão de batina e farda”, informa que a corregedoria da Polícia Militar do Estado de São Paulo desconfiou de assimetrias entre "seu patrimônio e seus vencimentos”, e garantiu, na justiça, a quebra do sigilo telefônico e bancário do ex-padre. O final da reportagem traz um veredito: “o quadro de capelão foi extinto”. Com a queda de Paló, o tão disputado cargo de tenente-coronel foi incorporado, finalmente, ao quadro de oficiais da PMESP. Na matéria do jornal O Estado de S. Paulo do dia 23/02/15, a mesma assertiva, agora dando crédito ao comandante-geral: "com a crise em torno da Capelania, o comandante-geral da PM, coronel Ricardo Gambaroni, decidiu acabar com o cargo de capelão militar - o sacerdote que é ao mesmo tempo oficial da corporação. Com isso, a vaga de tenente-coronel de padre Palópito será transferida para o quadro de oficiais da PM”.

\section{Os evangélicos: a expansão e hegemonia dos PMs de Cristo}

Artigo $1^{\circ}$ - Fica instituído o "Dia dos PMs de Cristo", a ser comemorado, anualmente, em 25 de junho.

Parágrafo único - A data de que trata esta lei homenageia todos os cidadãos policiais militares evangélicos e membros da Associação dos Policiais Militares Evangélicos do Estado de São Paulo (PMs de Cristo), passando a integrar o Calendário Oficial do Estado de São Paulo (Lei n. ${ }^{\circ}$ 14.798, de 6 de junho de 2012)

A Associação dos Policiais Militares do Estado de São Paulo (APMESP), mais conhecida como PMs de Cristo é, atualmente, o maior grupo religioso da PMESP. Maior em abrangência, em influência e em ambição. Com sede própria no bairro da Armênia, em um prédio anexo a uma igreja da Congregação Cristã do Brasil, o grupo 
representa, segundo seus levantamentos, 25 mil policiais evangélicos reformados e da ativa, distribuídos entre 50 núcleos na capital e no interior do Estado de São Paulo. Definem-se como uma associação sem fins lucrativos e interdenominacional - apesar de sua diretoria majoritariamente protestante, composta por membros da Igreja Batista, Igreja Metodista, da Congregação Cristã e da Assembleia de Deus - atuando na PMESP através de um termo de cooperação assinado entre a associação e o comando geral. Publicam, desde os primórdios do grupo, um boletim de informações mensais sobre o grupo.

A criação dos PMs de Cristo data, não por acaso, também de meados da década de 1990, nos batalhões policiais da região do Vale do Paraíba, como um grupo de policiais que se reuniam para orar após o expediente. Logo, assumiriam uma postura pacifista, buscando se diferenciar de uma corporação que gozava, como dito, de cada vez menos prestígio, chamando a atenção da imprensa. A crise na segurança pública da década de 90, além da formulação de propostas para a reforma das polícias, levou a uma série debates sobre a posse de armas e a campanhas de desarmamento voluntário da população. Os PMs de Cristo, à época, defendiam o desarmamento da própria polícia. Em matéria de capa da Folha de S. Paulo de 4 de fevereiro de 1996, o jornal faz referência a um “grupo autodenominado de PMs de Cristo', movimento que prega a ação não violenta dentro da polícia” e dá aspas à uma frase atribuída a um dos integrantes do grupo: "Deus dá a vida e somente Ele tem o direito de tirar" (Folha de S. Paulo 04/02/1996). Na reportagem interna, a manchete: “'PM de Cristo’ prega uso racional de arma".

Segundo a reportagem, dez policiais de São José do Rio Preto teriam iniciado, no final de 1995, um 'movimento' para pregar o evangelho junto à tropa. O teor da matéria ressaltava o tempo todo a filiação desarmamentista do grupo, posição assumida pelos entrevistados. Um cabo afirmou que, com Deus, "os policiais passam a pensar mais antes de fazer uso da arma”, enquanto outro policial disse que "é importante lembrar, antes de atirar, que somente Deus pode tirar a vida de uma pessoa”. Em 17 de março do mesmo ano, outra reportagem veiculada, dessa vez sobre um grupo denominado PMs de Cristo que havia sido criado na cidade de Batatais. 
A chamada da matéria era ainda mais incisiva: 'PMs de Cristo’ reduzem em 89\% a violência em Batatais”. Noticiava que, graças “um grupo de policiais militares que se reúne para orações e carrega a bíblia durante o patrulhamento”, o número de procedimentos administrativos e processos militares, que nos primeiros cinco meses de 1995 havia chegado a 34, caiu para 4 durante os sete meses de atividade do grupo. (Folha de S. Paulo 17/03/96). Esses PMs de Cristo eram, em relação aos de Batatais, mais moderados: visavam “auxiliar as pessoas carentes espiritualmente, com problema de relacionamento familiar e que precisam de apoio”. Ainda assim, colocavam que a sua maior conquista foi a grande diminuição de processos administrativos relacionados ao abuso de força física por parte dos policiais.

Um grupo pacifista no momento em que a nossa democracia experienciava seu momento mais violento; um grupo que se colocava, em nome das pertenças religiosas, na contramão da noção de corporação militar, questionando a própria autoridade hierárquica; um grupo que, ante uma corporação que se esfacelava simbolicamente, sentiu aflorar sua religiosidade passando a experimentá-la com mais intensidade do que nunca, a ponto de impeli-los a despedaçar os laços e renegar as doutrinas (Pierucci, 2006): é claro que não podia dar certo. Não tardou para que se iniciasse um movimento, em dois tempos, de desmonte dos diferentes PMs de Cristo que começavam a surgir.

Em um primeiro momento, houve o movimento de remanejamento dos integrantes mais afeitos à ideologia pacifista que começava a se alastrar pelos batalhões, sendo que estes foram designados para serviços internos ou burocráticos. Isso acarretaria, de certa forma, em boa parte da concepção de senso comum que pressupõe que há uma incompatibilidade entre a profissão de policial militar e a religião (cristã ou espírita), o que afastaria os religiosos do policialmente ostensivo para que não se ‘contaminassem’ com o serviço das ruas. Se isso chegou a acontecer em casos esporádicos, não passa de exceção: o serviço religioso nunca conseguiria se infiltrar e sobreviver com tanto sucesso nos meios militares se estes não fossem, pelo menos discursivamente, compatíveis. 
Em um segundo momento, há o movimento de ‘transferência’ da ideia de um grupo de policiais evangélico para a capital, mais perto do comando-geral; do lado dele, se possível: na APMBB. Todas as versões oficiais da associação situam geograficamente o início do grupo na academia, como um grêmio evangélico que teria sido criado a exemplo do grêmio católico. Essa estratégia visava, claramente, vigiar mais de perto o grupo. Sobre o processo de criação, um dos fundadores da associação, o coronel Terra, afirmou em uma sessão solene da Assembleia Legislativa do Estado de São Paulo (ALESP) em 24 de junho de 2013, na ocasião da comemoração pelo Dia do PM de Cristo:

Deus foi tocando, movendo corações de várias pessoas e como se fosse uma grande onda crescente, que ela culminou no ano de $1992 \mathrm{com}$ a criação e fundação da Associação, na época dos PMs Evangélicos que acabou nascendo na Academia do Barro Branco, foi naquele momento ali que nasceu o primeiro presidente coronel Alberto Resende, nós estávamos participando junto com ele ali naquele momento, capitão da Academia do Barro Branco

Sob a supervisão do comando-geral, os PMs de Cristo ganharam corpo institucional. Registraram identidade jurídica, aprovaram o estatuto da associação e garantiram que a diretoria fosse constituída pelo alto oficialato da corporação. Adequaram sua missão ao novo modelo de gestão da polícia, assumindo o compromisso de "valorizar a figura humana do policial, assistindo emocional e espiritualmente a família Policial Militar com base na mensagem, princípios e valores cristãos. Em harmonia com a missão da Polícia Militar do Estado de São Paulo e em parceria com a comunidade cristã evangélica e com os associados”. Harmonia com a missão da polícia seria, nesse caso, o ponto chave para que se permitisse iniciar um processo de franca expansão do grupo. Em 1999, uma reportagem do jornal O Estado de São Paulo noticiava que o grupo já contava com mais de mil associados (Estado de S. Paulo 01/01/99), em mais de 20 núcleos - conta que atualmente já bate os 50, distribuídos conforme o quadro abaixo: 


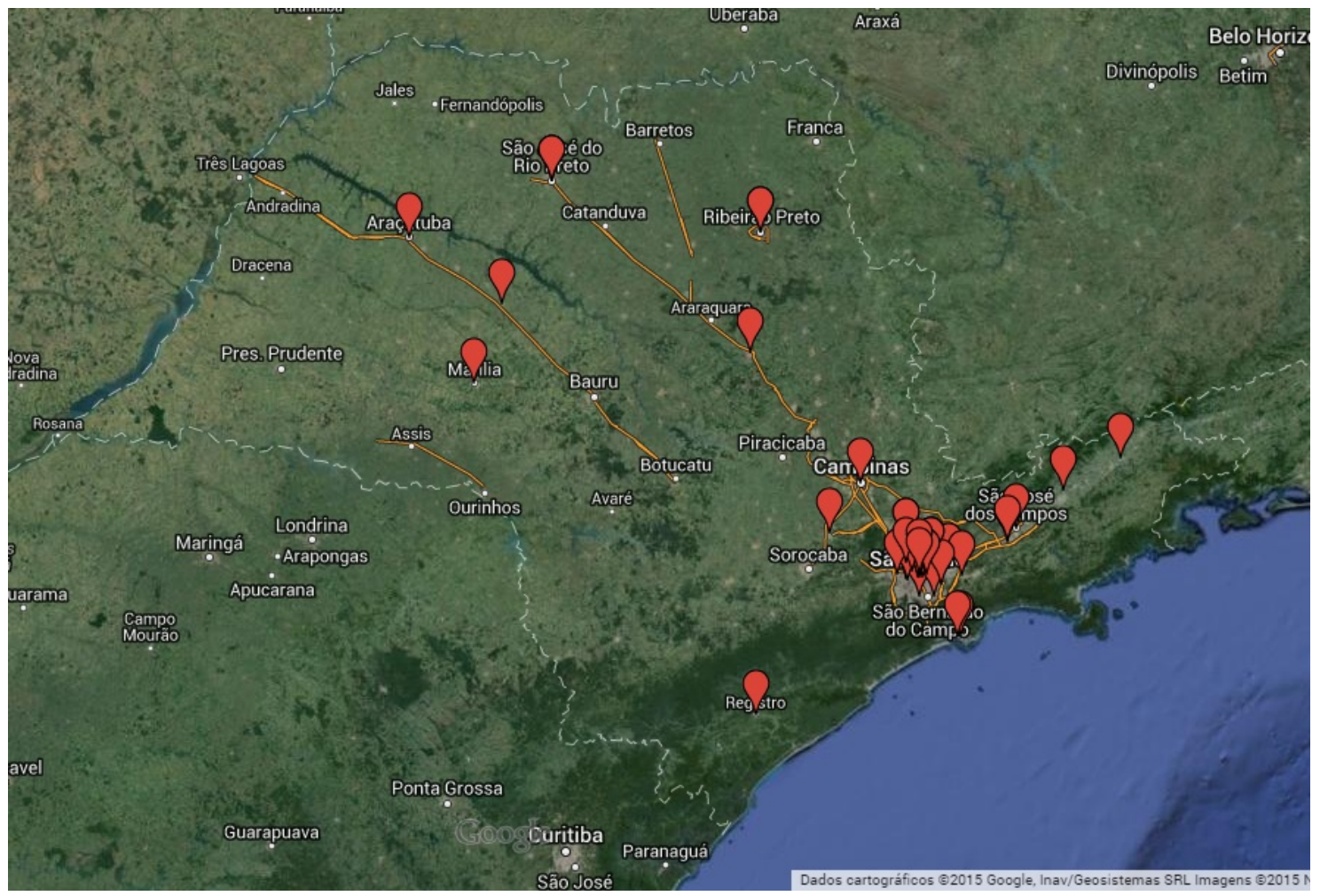

Imagem 03 - Distribuição geográfica dos núcleos dos PMs de Cristo no estado de SP${ }^{26}$.

(Fonte: Elaboração própria, a partir dos dados informados no site oficial)

No final de 2001, foi aberto o primeiro concurso público para a contratação de um capelão evangélico para compor o QOC da PMESP. Ofertando uma vaga para capelão católico e uma vaga para capelão evangélico, o concurso visava preencher o posto de capelão-auxiliar, que ficaria em aberto com a aposentadoria do então capelão católico Villano, que seria aposentado compulsoriamente em 2003, quando completaria 30 anos de serviços - cargo que viria a ser ocupado pelo capelão-auxiliar Palópito. Os requisitos eram os mesmos previstos na lei de 1981, incluindo a exigência de formação teológica de nível superior, e constaria, além de uma prova escrita, da avaliação do perfil psicológico dos candidatos. A prova, segundo o edital, versaria sobre um tema a ser sorteado entre vários listados, variando de acordo com a vaga pretendida. Entre os requisitos 'psicológicos', por assim dizer, era esperado, entre outras coisas, que o candidato fosse calmo, ponderado, cuidado, criterioso, autentico, que não apresentasse “características de passividade nem autoritarismo extremo”,

26 Dos 50 grupos, 29 deles se concentram na região metropolitana de São Paulo. O grupo ainda possui núcleos em São José dos Campos, Registro, São Carlos, São José do Rio Preto, Santos, Lorena, Jacareí, Lins, Itu, Ribeirão Preto, Marília, Araçatuba e Campinas. 
entre outros. Uma observação final advertia: "[O candidato] não deve colocar as prerrogativas militares à frente do dever de capelão". (DOE 05/12/01, Poder Executivo, Seção I)

Não houve inscrições para a vaga de capelão católico. Cinco candidatos se inscreveram para o cargo de capelão evangélico, tendo sido aprovado um pastor da Igreja Presbiteriana. O Diário Oficial do Estado (DOE) divulgou, em 19 de junho de 2002, o resultado final do concurso, com a orientação de que "os candidatos aprovados e classificados dentro do número de vagas previstas, deverão aguardar a nomeação em Diário Oficial pelo Excelentíssimo Senhor Governador do Estado, para fins de posse e admissão” (DOE 19/06/02, Poder Executivo, Seção I), nomeação que nunca chegaria a acontecer. Em 2001, com o falecimento do governador Mário Covas, assumiria o cargo o seu vice, Geraldo Alckmin. Como chefe do executivo estadual, Alckmin iniciaria um processo de reestruturação do quadro hierárquico da PMESP, que se baseava na extinção de cargos de oficiais auxiliares, como dentistas, médicos, músicos e capelães, visando à alocação desses recursos para a criação de novas companhias e batalhões.

Essas medidas tiveram impacto negativo na imagem do governador junto à PMESP, azedando as relações. A Lei Complementar n. ${ }^{\circ}$ 26, de 9 de dezembro de 2004, por exemplo, extinguiria o Quadro de Auxiliares de Enfermagem (QAE), juntamente com 167 postos do Quadro de Oficiais Médicos (QOM) em todo o estado. O deputado José Zico Prado (PT-SP), em nome da Associação dos Oficiais da PMESP, classificaria a reorganização promovida por Alckmin como "mudanças cosméticas, promovidas sob a falácia da 'melhora no policiamento ostensivo'”. Cosméticas ou não, fato é que, ante o modelo de estruturação proposto por Alckmin, a contratação de um oficial capelão era simplesmente impensável.

Mas as mudanças maiores no QOC ainda estavam por vir. Com a proposta de Lei Complementar n. ${ }^{\circ}$ 2, de 2006, colocada em regime de urgência, Alckmin propôs extinguir em definitivo, entre outras, cinco das seis vagas destinadas à capelania, à exceção daquela ocupada pelo padre Palópito. O argumento utilizado era o mesmo: “a reestruturação administrativa da Polícia Militar do Estado de São Paulo permitiria 
a criação de novas unidades de policiamento, melhorando a gestão da atividade fim”. Novamente, corporação e oposição se manifestaram contrariamente a proposta, que recebeu pedido de cerca de 50 emendas. A emenda 19, de José Zico Prado (PT-SP), propunha mudanças no texto da lei no que se referia aos capelães, e justificava:

O efetivo de Oficiais do Quadro de Oficiais Capelães PM é já muito pequeno, mesmo assim incompleto. Os Oficiais Capelães da Polícia Militar fazem parte da história e da tradição da Corporação, ou seja, é parte importante da memória da Polícia Militar, muito requisitados para atividades relativas ao apoio e assistência aos policiais militares e à sua família, agregando-os. Atualmente o Quadro de Oficiais Capelães está muito defasado, pois o Comando da Corporação há muitos anos não promove concurso para preenchimento das vagas existentes, nem toma medidas para promover o único Oficial Capelão PM, apesar de haver vagas em aberto. A presente Emenda de nossa autoria, mediante assessoria do Tenente Paz, conta com o apoio da Associação dos Oficiais da Reserva da Polícia Militar, sob a presidência do Coronel PM Hermes Bittencourt Cruz, e da Associação do Quadro Auxiliar de Oficiais da Polícia Militar do Estado de São Paulo, a qual busca preservar a carreira dos Oficiais Capelães PM, como uma questão da dignidade da pessoa humana, da cidadania e da prevalência dos direitos humanos, fundamentos da República, desses militares do Estado, e assegurar as condições necessárias à Polícia Militar para que possa preservar sua história, suas tradições e sua cultura, mesmo porque a polícia de um povo civilizado certamente não deve restringir-se apenas a atividades repressivas de seu povo, especialmente na preservação de uma ordem pública fundada em um sistema econômico e social dos mais injustos do mundo, mas, também deve preservar sua história e suas tradições.

A sutil crítica à obsessão pelo policiamento ostensivo por parte de Alckmin e o apelo à tradição mobilizados na justificativa não surtiram efeitos. Como tramitava em regime de urgência, o projeto de lei foi encaminhado a um relator especial, função que ficou a cargo do deputado Milton Vieira (PSD-SP), para a aprovação ad referendum. Peço licença para transcrever o parecer de Vieira sobre a emenda 19:

Quanto ao Quadro de Oficiais Capelães:

- a redução das vagas fixadas em lei no QOC tem como objetivo o ajuste às atuais necessidades da Instituição. Ademais, a Carta Republicana prevê em seu art. $5^{\circ}$, inciso VI, a liberdade religiosa e a garantia de seus cultos e o seu artigo 19, inciso I, veda à União, aos Estados, ao Distrito Federal e aos Municípios estabelecer ou subvencionar cultos religiosos ou igrejas; 
- contudo, a diminuição de 06 (seis) vagas de Oficiais Capelães para 01 (uma) vaga de Capitão não implica na extinção da Capelania, que continuará executando as mesmas atividades, pois, atualmente, só existe 01 (um) Capitão Capelão, que, na prática, coordena todos os serviços religiosos e sociais desenvolvidos, contando, também, com o apoio de representantes de outras religiões, o que tem propiciado a devida assistência religiosa aos policiais militares, respeitada a diversidade existente;

- a transformação de 05 (cinco) vagas do QOC em vagas do QOPM/QOPF possibilitará a formação do Comando (Tenente Coronel, Major, Capitão e Tenentes) de um novo Batalhão, que desenvolverá missões de polícia ostensiva e de preservação da ordem pública em locais onde a presença policial é menor em relação à população local, e mais carentes de estruturas públicas, propiciando, dentro de uma visão mais utilitária, a otimização de meios para a atividade-fim;

- as vagas do QOC não são preenchidas há décadas, mostrando sua atual inutilidade, bem como um excesso de vagas para execução desta atividade.

Não foi somente com a emenda 19 que o deputado foi duro: o parecer foi contrário a todas as emendas apresentadas, e o inteiro teor do projeto de lei foi aprovado, resultando na Lei Complementar n. ${ }^{\circ}$ 995, de 19 de maio de 2006. Ainda em relação ao concurso, aproximadamente um ano após a divulgação da classificação final, o deputado Paulo Sérgio (ex-PRONA, atual PV-SP) entrou com um pedido de Requerimento de Informação na ALESP, exigindo detalhes sobre o andamento do concurso. Justificava o pedido afirmando que "decorridos mais de 13 meses da divulgação do resultado final, não se tem notícia da nomeação de nenhum dos candidatos aprovados, o que nos leva a acreditar que os respectivos postos se encontram vagos até a presente data”, e fazia seis questionamentos:

1.- Em que data foi realizado o concurso para o preenchimento de duas (02) vagas para o posto de $2^{\circ}$ Tenente Capelão PM Estagiário da Polícia Militar do Estado de São Paulo, objeto do Edital n ${ }^{\circ}$ CSAESP - 96/01?

2.- Quais foram os candidatos classificados para as vagas destinadas às religiões Católica Apostólica Romana e Evangélica, respectivamente?

3.- Os candidatos aprovados foram nomeados para os respectivos postos? Quando ocorreram as nomeações? 
4.- Qual foi o candidato nomeado para o posto correspondente à religião católica?

5.- Qual foi o candidato nomeado para o posto correspondente à religião evangélica?

6.- Caso algum deles ainda não tenha sido nomeado, qual a explicação para o fato e qual a circunstância que está impedindo tais nomeações?

Afora o detalhe de que mais da metade dessas questões pudessem ser respondidas com uma simples consulta aos arquivos do DOE, fato é que o relatório de resposta ao requerimento não trazia qualquer informação relevante, limitando-se a afirmar que se aguardava a abertura de vagas junto ao departamento de pessoal da PMESP. O requerimento de informações protocolado pelo deputado era, na verdade, uma demanda da própria Igreja Presbiteriana, interessada na contratação de seu pastor. Aqui, inicio uma pequena digressão: à medida que as relações da Igreja Católica com os militares do período de exceção se tornavam cada vez mais conturbadas, outros grupos religiosos - leia-se evangélicos - passaram a granjear um lugar mais próximo das potenciais benesses que as alianças com o Estado poderiam conceder. Segundo Mariano,

em face da oposição católica, o Estado de exceção, privado desse apoio na sociedade civil, rompe com sua prática política de privilegiar esse grupo religioso em prejuízo dos demais, passando a costurar alianças com (e barganhar o apoio de) novos interlocutores religiosos, visando à legitimação de sua autoridade e do exercício de seu poder. Os evangélicos destacam-se entre estes aliados, tanto por seu encarniçado anticomunismo, sua inclinação pelo clientelismo, como pela ávida busca - motivada por sua condição de minoria discriminada - de poder, recursos, reconhecimento social e político (2001: 153).

Impulsionados em boa parte por esse período de entendimento com o regime, começam a pipocar no período aquelas que seriam as primeiras associações de capelães evangélicos das forças armadas e nas policiais. É nessa época que surgem, por exemplo, a União dos Evangélicos da Polícia Militar do Estado do Rio de Janeiro, em 1967; a Ordem Nacional de Capelania Cristã (ONCC), em 1970; e a Associação dos Oficiais Cristãos (AOC), em 1979. Frente ao desafio de organizar, estruturar e, por que não, prover o serviço de capelania evangélica, esses grupos promoviam 
encontros para congregar as associações de capelães que atuavam nas várias corporações militares. Foi a partir desses encontros que se decidiu criar a União dos Militares Cristãos Evangélicos do Brasil (UMCEB), em 1985; e a Aliança Pró Capelania Militar Evangélica Brasileira (ACMEB), em 2003.

A UMCEB tinha como objetivo, no seu estatuto, reunir as várias associações de capelães evangélicos existentes espalhadas pelo Brasil; enquanto a ACMEB, por sua vez, se propunha, desde a sua criação, a servir de interlocutora e representante dos capelães evangélicos com o poder público, identificando a ausência de uma parceria ao modelo daquela estabelecida pela Igreja Católica a partir da concordata de 1989. Peço licença, mais uma vez, para mostrar um excerto, talvez excessivamente grande, retirado do seu histórico:

A despeito do avanço da legislação federal pertinente ao Serviço de Assistência Religiosa das Forças Armadas (e, por vias de consequência, da legislação de vários Estados quanto as Capelanias das Policias Militares e Corpos de Bombeiros), diversas lacunas têm sido identificadas, merecendo especial e cuidado atenção de varjas Igrejas Cristãs, sobretudo por causa da importância desse serviço junto aos homens e mulheres que oferecem suas vidas em favor da paz e segurança da nossa sociedade. Nesse sentido, torna-se digno de reconhecimento o avanço que a Igreja Católica Apostólica Romana empreendeu a partir do Concilio Vaticano II. Desenvolveu ela, desde então, um formato do Vicariato Militar possuidor de dispositivos organicofuncionais complementares a legislação peculiar da Assistência Religiosa das Forças Armadas e Auxiliares dos países interessados, a exemplo do que veio a ocorrer no Brasil. A Constituição Apostólica "Spirituali Militum Curae" instituída por Joao Paulo II, em Roma, dia 21 de abril de 1986, (documento normativo do Vicariato Militar objeto de decisão daquele Concilio), o "Acordo entre a Republica Federativa do Brasil e a Santa Se sobre Assistência Religiosa as Forças Armadas de 23-10 -1989, e os " Estatutos do Ordinariato Militar do Brasil", de 02-01-1990, seguidos do modelo de Serviço de Assistência Religiosa Católico implementado junto as Forças Armadas e Auxiliares brasileiras baseado em tais documentos, exemplificam e comprovam o acerto na escolha do caminho adotado pela Igreja Católica Apostólica Romana quanto ao assunto em apreço. Por outro lado, nos, os Evangélicos, a despeito dos inúmeros esforços realizados, quer por denominações, isoladamente, quer por entidades paraeclesiásticas, a exemplo da antiga Confederação Evangélica do Brasil, da Ordem dos Ministros Evangélicos do Brasil, da Associação Evangélica Brasileira, do Conselho Nacional de Igrejas Cristas, do Conselho Nacional de Pastores, União dos Militares Cristãos Evangélicos, dentre outras, não conseguimos progredir o suficiente para concebermos um modelo eclesiástico mais adequado as Capelanias 
Militares Evangélicas do Brasil. Todavia, fatos recentes têm contribuído favoravelmente na indicação de novos caminhos rumo a uma solução para essa lacuna existente no âmbito interdenominacional e entre este e as autoridades e instituições governamentais brasileiras.

A ACMEB, em busca de sua própria concordata, selaria em definitivo a predominância dos protestantes nos serviços de capelania evangélica militar, entendendo-o como uma extensão do caráter missionário, tão marcadamente impregnado em suas teologias. Seria, ainda, exitosa em suas pretensões de representação junto ao poder público, graças ao apoio irrestrito de membros da Frente Parlamentar Evangélica. Em 2012, ponto alto da associação, garantiria assento permanente na COSARFA, com direito a voto nas deliberações. Foi a partir da ACMEB, e aqui encerro a digressão, que a Igreja Presbiteriana do Brasil passou a questionar o concurso público da PMESP. O Sínodo Unido/Presbitério de Pirituba, unidade organizacional da igreja, decidiu em assembleia protocolar um ofício denunciando que haveria um pastor presbiteriano impedido, "por problemas políticos”, de tomar posse do cargo ao qual tinha direito, e exigindo que fosse

encaminhado à Assembleia Legislativa do Estado de São Paulo e/ou Gabinete do Governador do Estado pedido de resolução do entrave político que envolve o pastor aprovado em concurso, bem como pedido de abertura de concurso público para a contratação de capelães em número proporcional à necessidade de assistência religiosa ao efetivo da Polícia Militar do Estado de São Paulo

A Igreja Presbiteriana, que figurava no rol de entidades fundadoras da AMCEB, acionou a associação, que garantiu que o pedido fosse protocolado - sem surtir, no entanto, o efeito desejado. Sem capelão evangélico no QOC, os PMs de Cristo continuavam a criar novos núcleos e a se expandir pelo interior do estado, trabalhando em caráter voluntário. Começaram a ganhar visibilidade na corporação, de modo geral, e com o comando-geral, especificamente. Suas atividades consistiam - e consistem até hoje - na realização de vigílias, reuniões de oração após o expediente, participação nas cerimônias de recepção e formatura das escolas de formação, na distribuição de bíblias e devocionais personalizados, entre outras atividades. Atraíram visibilidade da imprensa, que passaria a analisa-los não mais 
como um grupo pequeno e asceta, mas como um fenômeno a ser observado e compreendido dentro da PMESP.

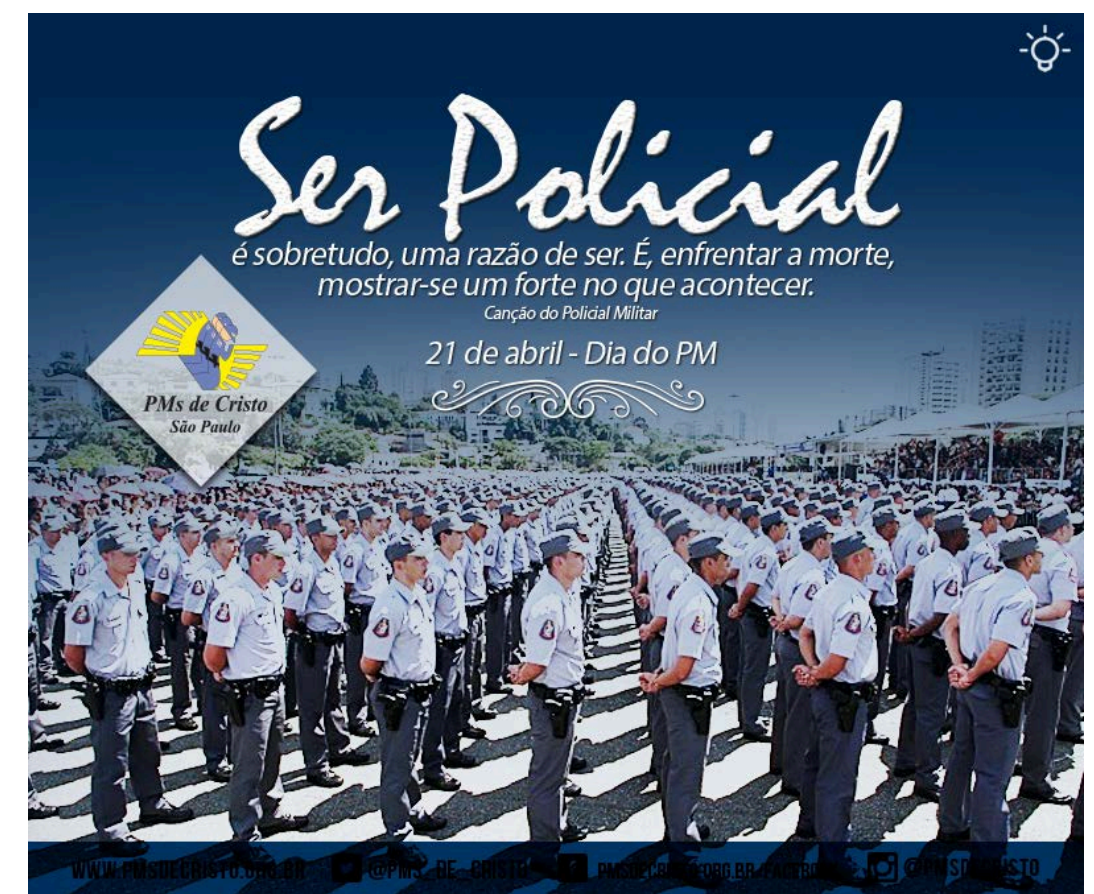

Imagem 04 - Homenagem dos PMs de Cristo ao dia do Polícia Militar (Fonte: Assessoria de Imprensa)

Na edição de 16 de março de 2008, o jornal Estado de S. Paulo dedicaria uma página inteira aos PMs de Cristo, cobrindo a visita que eles realizaram a um batalhão na zona norte. Na ocasião, nove policiais haviam sido presos acusados pela morte do comandante do batalhão, e os capelães civis voluntários dos PMs de Cristo foram até lá para prestar apoio psicológico aos policiais que restaram. A matéria trouxe uma entrevista com o coronel Terra, e abordou o trabalho de ressocialização que o grupo realizava junto aos presos do presídio militar Romão Gomes. Na entrevista, Terra afirmou, ambiciosamente, que o projeto do grupo era poder prestar esse tipo de serviço “nas mais de 400 companhias do estado” (Estado de S. Paulo 16/03/08). No mesmo ano, o Portal do Governo do Estado de São Paulo veicularia matéria com a chamada: “Há 15 anos PMs de Cristo promovem melhor qualidade de vida do policial”, focando também no caráter assistencial do grupo ${ }^{27}$.

27 Disponível em <http://www.saopaulo.sp.gov.br/spnoticias/lenoticia.php?id=96189>. Acesso em 24 de agosto de 2014. 


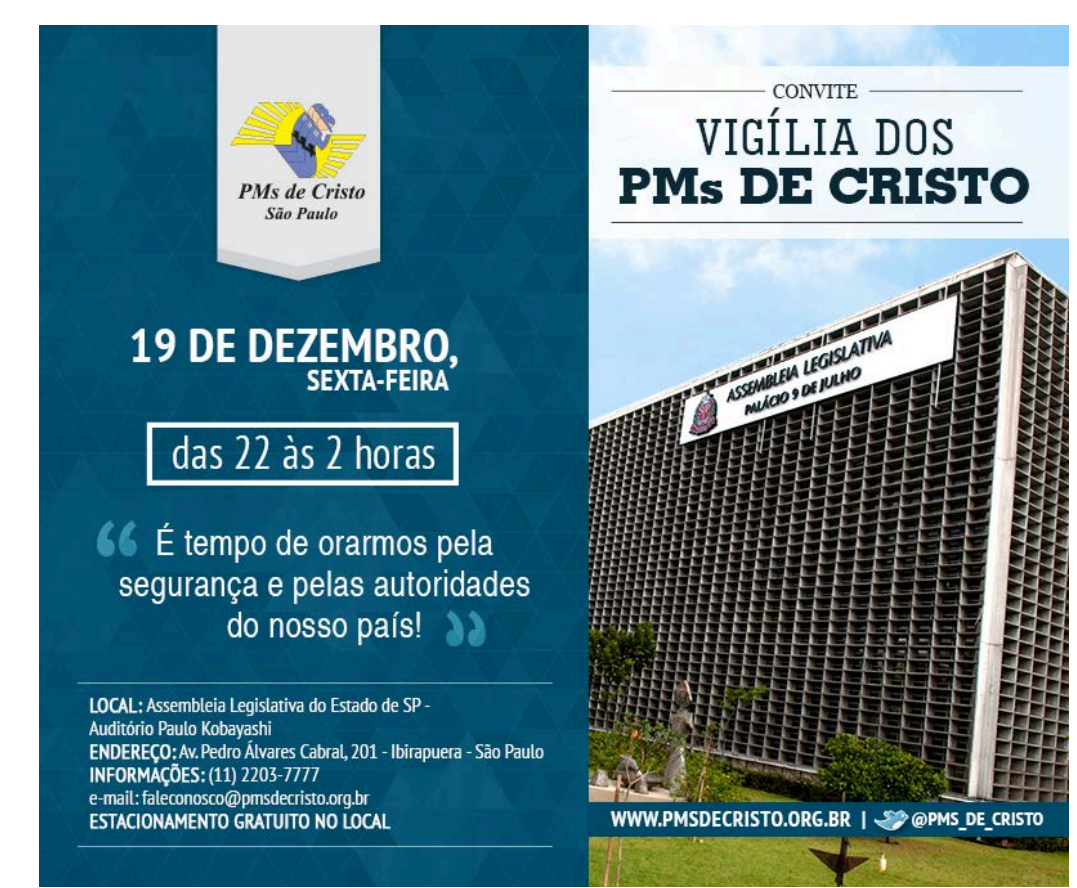

Imagem 05 - Convite para o culto de vigília mensal dos PMs de Cristo.

(Fonte: Assessoria de Imprensa)

O crescimento do grupo demandaria a criação de um corpus doutrinário, fazendo-se necessário estabelecer os princípios daquilo que seria a atuação de um policial evangélico - não um evangélico policial, o que faz alguma diferença. É nesse sentido que os PMs de Cristo editam os livros A missão de Deus para o Policial (Barreto Neto, 2012); Com o sacrifício da própria vida (Terra; Silva, 2007); e A Polícia e a Igreja: uma parceria para o desenvolvimento da comunidade e o combate à violência (Alves, 2012). Os livros trazem depoimentos de conversão e histórias de vivências policiais atravessadas pela fé, além de ensinamentos e conselhos para a conciliação da profissão com a religiosidade.

O livro de Terra e Silva (2007) faz bom uso da utilização de depoimentos de ex-policiais corruptos como prova da mudança de vida de que Deus é capaz. Um exemplo é o depoimento do Tenente Pereira, ex-comandante de um pelotão de Tático Móvel que foi condenado, à época com 28 anos de idade, a 43 anos de prisão, acusado de tortura e assassinato. Pereira conta que o cotidiano de policial militar, de onde presenciava cenas de violência e injustiça ocasionou uma mudança em sua personalidade. Afirma que em um momento paradigmático de sua vida, 
[r]evoltado e com o coração cheio de ódio, tomei uma decisão, resolvi ocupar o lugar de Deus. Tirei a letra "D" e a letra "S" dessa palavra e então sobrou uma palavra de duas letras que infelizmente tem destruído muitas vidas: "EU” (Terra; Silva:, 2007: 33)

Narra Pereira que, ao invés de encaminhar os indivíduos detidos à delegacia de polícia, levava as vítimas para um lugar ermo e "dava um minuto para que o desafeto criminoso orasse a um deus em que acreditasse, pois aqueles seriam os seus últimos momentos”. Atuava, nas palavras dele, como “advogado, promotor e juiz”. Invariavelmente, “a sentença era sempre a mesma: pena de morte!” (Terra; Silva:, 2007: 33).

Fiel à lógica dos depoimentos de conversão por parte de indivíduos tidos como sujeitos irrecuperáveis (Côrtes, 2007), diz Pereira que, do ponto de vista psicológico, tinha sido desacreditado por todos os profissionais que o avaliaram. Diz ele que foi "submetido a exame criminológico, ou seja, fui entrevistado por um psiquiatra, um psicólogo e um assistente social e o relatório desses três profissionais concluía que eu não poderia mais retornar à sociedade” (Terra; Silva:, 2007: 34). Assim, contrariando qualquer possibilidade real de regeneração, passa a creditar à sua conversão religiosa o fato de ter se arrependido e redimido dos seus erros. Em pensamento, Pereira responde ao chamado de Deus, que o chama e o interpela a se arrepender. Tal fato marca o momento em que Pereira reconhece a sua verdadeira mudança: "Hoje”, afirma ele, “estou em liberdade, feliz com minha família, tenho o meu trabalho. Esta é parte da minha história de vida e conto-a como testemunho, de que nada é impossível para Deus” (idem: 34).

Se o testemunho de conversão de Tenente Pereira marca uma situação limite de mudança de comportamento, outros depoimentos fazem alusão a uma modificação na conduta do policial militar através da crença e da fé. Sobre o trabalho evangelístico dos PMs de Cristo, um policial diz que este trabalho é importante por trazer "uma palavra amiga, um conforto que faz com que um policial que esteja com pensamento de cometer alguma loucura, reflita e procure outra maneira de resolver seus problemas...” (Terra; Silva, 2007: 16). Da mesma forma, outro depoente afirma que a 
evangelização do quadro de funcionários da polícia militar os auxilia a realizar o seu trabalho "a contento":

Se o nosso homem, antes de tudo, não estiver preparado para ajudar o próximo, ele não vai conseguir realizar a contento o seu serviço junto à população. A palavra não só de orientação, mas de conforto espiritual, para nós, que trabalhamos numa companhia operacional, é muito importante... (1 $1^{\circ}$ Tenente PM Takarabe) (Terra; Silva, 2007:16).

Barreto Neto (2012), policial evangélico e autor do livro A missão de Deus para o Policial, relaciona de forma parecida os preceitos da profissão e da fé cristã. Entende a profissão como servidão a Deus, não pela profissão de fé do indivíduo que, defende, nem precisa ser cristão para ser servo de Deus - mas pelo caráter de justiça, honradez e serventia do trabalho que executa. Em determinado momento, afirma que

Muitos policiais têm honrado o juramento que fizeram, mas, infelizmente, muitos outros, por não conhecerem o mundo espiritual, ignoram que um dia Deus os irá julgar por todos os seus atos. Em seu desconhecimento de Deus, descumprem o juramento que fizeram perante o altar da pátria, aliando-se às forças do mal, passando a ser mais um motivo de insegurança para a sociedade (Barreto Neto, 2012, p. 16-17) 


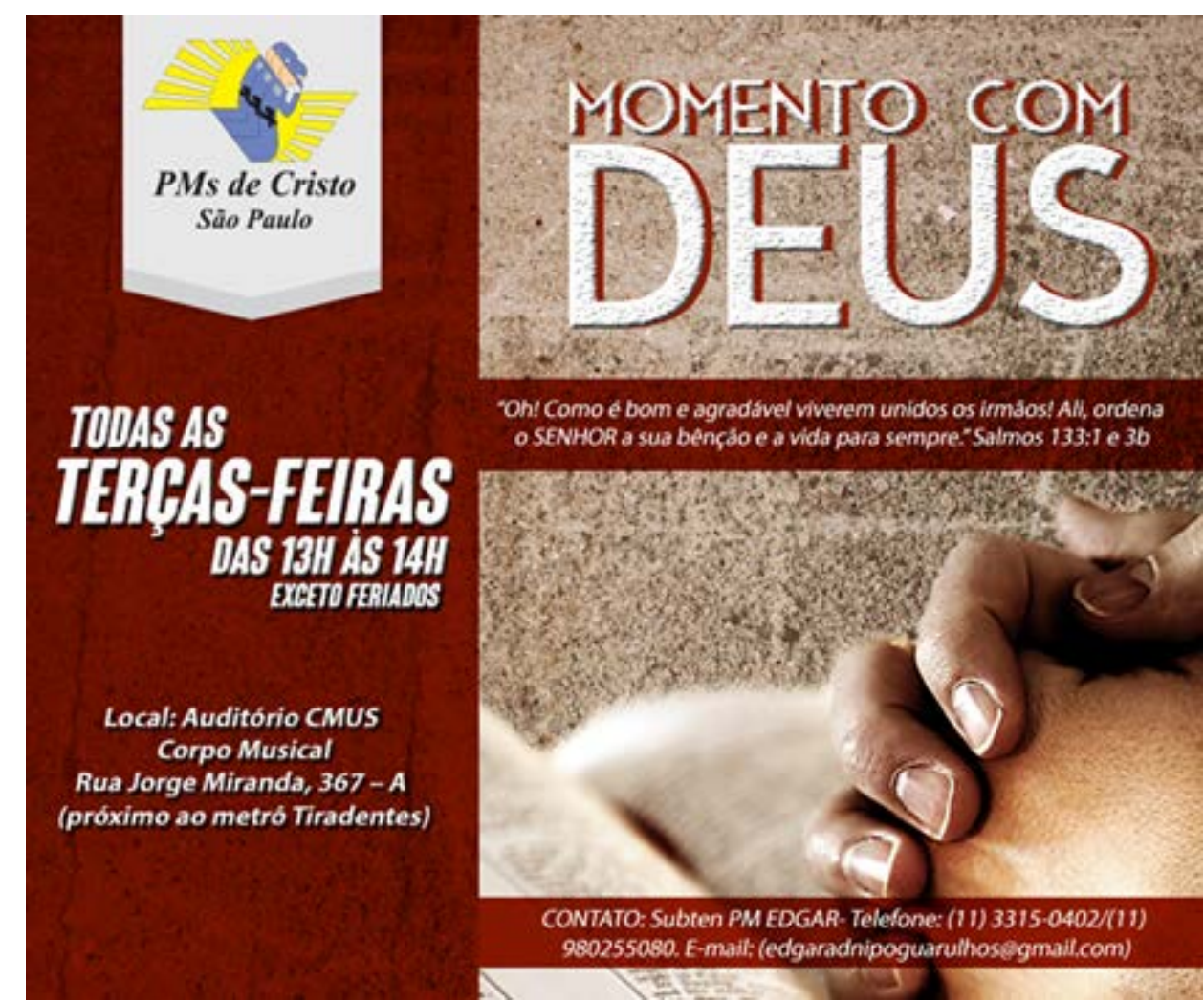

Imagem 06 - Divulgação da reunião de oração semanal dos PMs de Cristo.

(Fonte: Assessoria de Imprensa)

Mas o proselitismo das obras editadas pelo grupo parece não convencer todo mundo. Em nova inserção na imprensa, o jornal Folha de S. Paulo produziu uma vídeo-reportagem de 4 minutos intitulada "PMs de Cristo contra o baixo-astral"28. Algo irônica, a reportagem alterna cenas de violência policial, como a repressão nas manifestações de junho de 2013 e as torturas da Favela Naval com depoimentos do Coronel Terra sobre o autocontrole emocional e psicológico preconizados pelo grupo. Na chamada do vídeo, a descrição:

Eles têm um livro de pílulas bíblicas para a Rota e uma Bíblia customizada que leva "a palavra de vida e esperança ao policial militar”. Na capa azul com detalhes dourados, três PMs ajoelhados e com mãos de oração. Cuidam de "policiais que ficaram possessos por demônios" e querem dar "muita direção de Deus para [o PM] não fazer besteira”. E pedem para que o "civil” lembre: "Todos nós somos seres humanos, temos coração, temos alma e muitas vezes choramos”. Conheça os positivos e operantes PMs de Cristo, que montaram uma

28 A chamada faz referência ao filme infantil protagonizado pela atriz Xuxa, intitulado "Super Xuxa contra o baixo-astral”. 
capelania para dar "assistência emocional” a cerca de 23 mil policiais evangélicos do Estado de São Paulo. ${ }^{29}$

\section{Os espíritas kardecistas: a discrição e a regularidade dos PMs a Caminho da Luz}

O grupo dos policiais espíritas é, sem dúvida, o mais discreto e o mais regular entre os que atuam na corporação. Nascido da vontade de extensão do grêmio espírita para além dos muros da caserna, suas reuniões passaram a ser realizadas na Capela Ecumênica da APMBB, denominada Casa do Caminho. O grupo reúne-se todas as quintas-feiras, e seus participantes, cerca de 30 em cada reunião, leem o evangelho espírita, recebem orientação e recebem e ministram os passes.

Não fosse pela presença de alguns poucos policiais fardados que se dirigem até o local após o expediente, talvez fosse impossível diferenciar as sessões que ocorrem nas dependências da academia de tantas outras realizadas país afora. A organização das reuniões e as mensagens e estudos lá realizados em nada fazem referência a questões de segurança pública, policiamento ou estratégias santificadas de combate ao crime. Os estudos são feitos tomando por base. Os temas como a morte e a violência, por exemplo, são estudados a partir das dimensões do sempre referenciado tripé da construção do conhecimento kardecista: enquanto filosofia, enquanto ciência e enquanto religião ${ }^{30}$.

29 Disponível em <http://www1.folha.uol.com.br/poder/2014/08/1499262-religiosamente-pms-decristo-contra-o-baixo-astral.shtml>. Acesso em 14 de agosto de 2014

30 Para não correr o risco de desdramatizar os conflitos, na precisa expressão de Pierucci (1996), ver os trabalhos de Célia Arribas (2010, 2014), onde a socióloga consegue mapear os caminhos e tensões da constituição e da consolidação do movimento espírita no Brasil. 


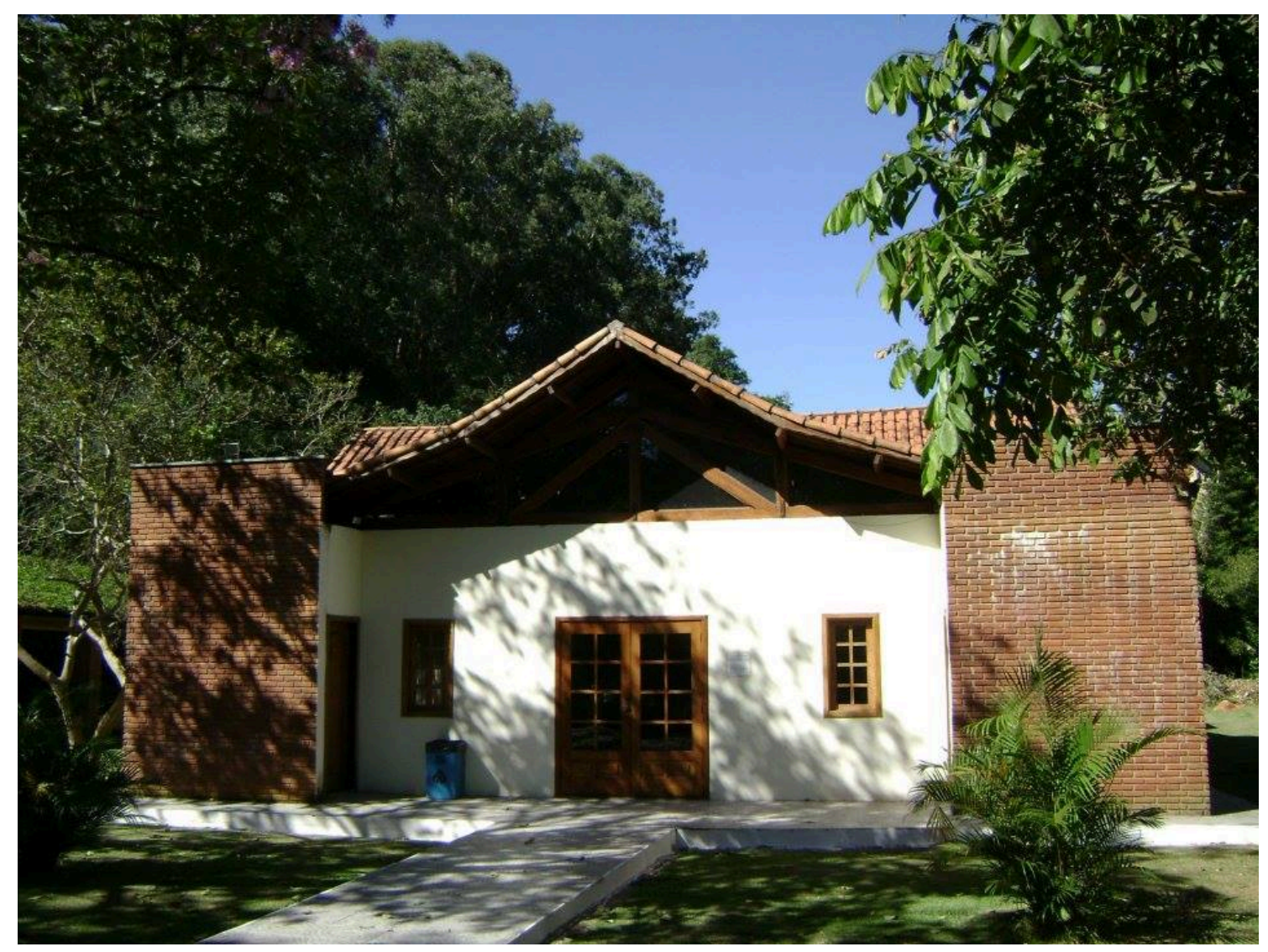

Imagem 07 - Capela Ecumênica Casa do Caminho, nas dependências da APMBB (Fonte: Acervo / Autorização)

No final da primeira década dos anos 2000, os dirigentes resolveram oficializar o grupo junto ao comando. Seguiu-se, então, um período em que o grupo passou a ser pensado como uma associação, a Associação dos Policiais Militares Espírita do Estado de São Paulo, associação que traria, como nome fantasia, num primeiro momento, esse simpático nome de PMs a Caminho da Luz, e que depois seria pensada para se chamar PMs da Fé no Bem. O policial da PMESP que dirigia o projeto de institucionalização, oficial de nível superior, me disse à época que o objetivo da empreitada era pleitear, ao menos em parte, a mesma visibilidade e prestígio que vinha conquistando o grupo dos PMs de Cristo junto ao comando.

No seu estatuto, a associação colocava como finalidade "tríplice aspecto: filosófico, científico e religioso, com base na Doutrina Espírita codificada por Allan Kardec e nas obras que, seguindo seus princípios e diretrizes, lhe são complementares e subsidiárias”. Reforçava o caráter assistencial da associação (que permanece até hoje), e focava a atuação nos "policiais militares e respectivos familiares; a família 
policial militar”. Aos moldes dos PMs de Cristo, o estatuto previa ainda que a associação seria composta por núcleos regionais e locais, distribuídos e atuando em todo o território estadual, e, do ponto de vista doutrinário, determinava:

Os Núcleos não terão tendências denominacionais, sendo que o dirigente deve seguir a essência e a simplicidade do Evangelho do Senhor Jesus Cristo, evitando qualquer discussão de pontos secundários (doutrinas polêmicas, costumes específicos de igrejas ou questões não essenciais à verdadeira fé cristã).

O projeto de institucionalização, no entanto, arrefeceu, tendo sido completamente abandonado no ano de 2014. O mesmo oficial que liderava o projeto me informou que tal abandono se deu por questões estritamente práticas, particularmente a falta de um articulador no alto escalão da PMESP que tramitasse as questões burocráticas que envolviam a criação de uma identidade jurídica para o grupo. As reuniões, no entanto, seguiram firme e forte, com um número cada vez maior de frequentadores e espraiando-se para a comunidade espírita local, que já representava um filão até maior do que o de policiais. Do ponto de vista formal, a única ligação política do grupo com a PMESP era a autorização do comando da corporação para a utilização do espaço ecumênico.

\section{Os afro-brasileiros: os conflitos e tensões dos PMs de Axé}

PMs de Axé não busca criar uma "Casa de Santo", nem um "Ilé Axè", ou um Templo. Buscamos reunir Policiais Militares para que nós nos conheçamos e nos protejamos, pois há uma grande perseguição religiosa dentro da Polícia Militar aos PMs que são umbandistas ou candomblecistas. Temos que mostrar que nós realmente existimos. Não nos importamos se o Policial Militar é de Angola, Ketu, Efan, Efon, Egba, Xambá, Omolokô, Umbanda Esotérica, Umbanda Sagrada, Umbanda Divina, Umbanda Branca ou o que for. Importamos, sim, com o amor que o PM tem pelos Orixás, Voduns, Inkices, guias espirituais, entidades espirituais etc. (Folheto de divulgação dos PMs de Axé)

O processo de criação, institucionalização e ocaso do Núcleo das Religiões Afro-Brasileiras da Polícia Militar de São Paulo - NAFRO-PM/SP, mais conhecido 
como PMs de Axé, está intimamente ligado à parte da trajetória de vida do Babalorixá Flávio de Yansan. Na verdade, sem medo de incorrer em exageros, essas se confundem. Mobilizados por uma denúncia de discriminação e intolerância religiosa por parte dos PMs de Cristo, o grupo viria a se estabelecer como um ponto de resistência na configuração religiosa da PMESP, agitando-a e ressaltando os conflitos e tensões do campo religioso, principalmente naquele circunscrito à PMESP.

Pai Flávio é um ebômi, sacerdote experienciado e feito há bastante tempo no orixá, pai-de-santo e vice-presidente do Ilê Axé Alaketu d’Oyá e d’Ogum Comunidade de Oyá e de Ogun desde 1981, além de um militante ativo na luta contra a discriminação racial, intolerância religiosa e a homofobia. Foi condecorado com o prêmio Santo Dias de Direitos Humanos pela ALESP em 2005, tendo sido o primeiro Babalorixá a receber a honraria ${ }^{31}$. Perto da magia, perto da política. Desde 2004 ele editora e publica o jornal A Gaxéta (AG), um informativo mensal destinado ao povode-santo da região metropolitana de São Paulo. O jornal veicula informações de utilidade pública, artigos sobre religião, saúde, direitos humanos e denúncias de casos de intolerância e discriminação. Foi através da AG que Pai Flávio recebeu a denúncia sobre os PMs de Cristo, no ano de 2006.

$\mathrm{Na}$ ocasião, chegou ao seu conhecimento que o grupo ativista LGBT Identidade, de Campinas, havia protocolado uma denúncia junto à Secretaria de Direitos Humanos sobre o conteúdo discriminatório de cartilha intitulada “O caminho, a verdade e a vida”. Nela, três quadros mostram momentos distintos da história da humanidade. O primeiro quadro, mostra o momento em que "o povo desprezou a Deus e se entregou à prática de feitiçaria, encantamento e magia negra”, recheado de imagens bestiais e fantasmagóricas. No segundo quadro, lê-se: “Com toda a sua inteligência o homem tornou-se tolo, e trocou a Glória de Deus por essas imagens vãs e as adorou”. As imagens vãs vão desde Nossa Senhora, passando por Buda, Krishna e o monumento Stonehenge. O terceiro quadro mostraria os resultados do processo. “Nos dias de hoje... Embriaguez e jogos de azar, homossexualismo, adultério,

31 Disponível em < http://www.ilease.org.br/html/babalorixa.html>. Acesso em 24 de agosto de 2014. 
depuração, assassinato e roubo, prostituição”, cada uma dessas 'consequências' devidamente ilustradas (AG 06/06). A cartilha trazia o logotipo dos PMs de Cristo.

A Secretaria de Justiça determinou que os PMs de Cristo recolhessem as cartilhas, e arrolou Pai Flávio como testemunha no processo. Frente a isso, considerou que era hora, nas suas palavras, de "botar o povo-de-santo dentro da polícia". Solicitou, no início de 2008 ao então secretário de Justiça e Cidadania, Luiz Antonio Marrey, que iniciasse e intermediasse um processo de negociação com o secretário de segurança pública, Ronaldo Marzagão. Pai Flávio pôde expor, então, o seu plano de criar um núcleo de combate à intolerância religiosa na PMESP, à semelhança do NAFRO-PM, ideia prontamente acolhida por Marzagão. Este determinou uma reunião, que ocorreu no início de 2007, entre ele, Pai Flávio e o comandante-geral da PMESP, à época o coronel Roberto Diniz. O comandante ordenou ao Major PM Justus e à Major PM Clarice, responsáveis pela Divisão de Polícia Comunitária e Direitos Humanos (DPCDH), que oferecessem todo o suporte necessário para a institucionalização do NAFRO-SP.

A narrativa de Pai Flávio deixa clara a gratidão que sente pelas pessoas envolvidas neste processo, principalmente em relação ao Major Justus e à Major Clarice - “que é evangélica!”, como ele faz questão de frisar. Na verdade, Pai Flávio sempre foi próximo da polícia militar, ainda que essa proximidade fosse um tanto ambígua. Por um lado, tinha feito os seus ritos de 21 anos com Baba Pece de Oxumaré, na Bahia, que também é policial - foi ele, inclusive, quem o apresentou à iniciativa do NAFRO-PM/BA, que serviu de modelo para o núcleo paulista. Ainda, seu terreiro, situado na região do Planalto Paulista, era muito frequentado pelos cabos e soldados da PMESP. Por outro lado, nutria certa desconfiança em relação aos oficiais, os quais considera “racistas, elitistas e preconceituosos”. "São impermeáveis”, afirma. Mas Pai Flávio se sentiu animado com a boa recepção.

Através da AG, passou a publicar uma série de convocatórias e notas, esclarecendo o que se propunha com a criação do grupo. Conforme aumentou o número de interessados, convocou, em julho de 2007, uma assembleia para definir o estatuto e definir a composição da diretoria. A presidência ficou a cargo do PM Cabo 
Alexandre, e a vice-presidência a cargo de um oficial. Pai Flávio assumiria o posto de assessor religioso do grupo, e a tesouraria ficaria sob os cuidados de uma civil, também candomblecista. Como prerrogativas do grupo, entre outras coisas, estaria a defesa da cultura e das religiões afro-brasileiras, o combate à discriminação dos policiais adeptos das religiões afro-brasileiras, o acompanhamento religioso dos policiais militares e a assistência aos policiais militares dependentes químicos. Em parágrafo único, uma condição que se mostraria extremamente problemática no futuro: "Nas relações administrativas e sociais do NAFRO-PM/SP, não imperará a hierarquia e autoridade militar, e sim, a hierarquia e relações religiosas”.

Em pouco menos de três anos, os PMs de Axé já contariam com mais de 150 associados, entre civis e policiais militares. O grupo passaria a atuar como um importante interlocutor entre o povo-de-santo e as polícias, com propostas de elaboração de cartilhas com orientações para os atendimentos policiais aos terreiros e com a realização de workshops e cursos nas escolas de formação. As reuniões aconteciam no terreiro de Pai Flávio, no Planalto Paulista, mas os PMs de Axé se faziam presentes em cerimônias e sessões oficiais da PMESP.

Entre 2009, com uma série de escândalos envolvendo a Secretaria de Segurança Pública levou à renúncia de Marzagão, seguido da renúncia do então governador José Serra para concorrer à presidência, ocorre uma restruturação da cadeia de comando da PMESP, incluindo a Diretoria de Policiamento Comunitário e Direitos Humanos. Pai Flávio, segundo conta, se vê obrigado a 'reapresentar’ o grupo aos novos diretores, que não teriam se demonstrado muito entusiasmados. Afirma que, com a nova gestão, passou a se sentir preterido e colocado “de escanteio”.

Além dos ruídos de comunicação com a nova diretoria, Pai Flávio se viu obrigado a ter que administrar vários conflitos hierárquicos no âmbito interno dos PMs de Axé. O presidente do grupo era filho-de-santo de Pai Flávio, e exercia o cargo, no terreiro, de ogã. Portanto, era cabo da polícia militar e também um ebômi. O tesoureiro, oficial capitão, era um iaô, filho-de-santo feito há pouco tempo. Pois bem. Há no candomblé, segundo Prandi (1996: 144), uma lei que diz: “Orixá novo não tem querer, como iaô não tem saber”. Na polícia militar, por sua vez, há uma doutrina que 
afirma que cabo, em hipótese alguma, dá ordens para capitão. Ou seja: de nada adiantaria a cláusula do estatuto: a hierarquia religiosa e a hierarquia militar eram incompatíveis. Se for possível traçar um paralelo, enquanto a capelania católica e a organização dos PMs de Cristo preconizam uma conformação entre hierarquia militar e a estruturação do serviço religioso, Pai Flávio insistia na primazia das relações religiosas sobre as relações militares. Pior, quem tentava mediar os conflitos - ele, no caso - era um civil. Essa situação, aos poucos, começava a minar o seu entusiasmo.

A oficialização dos PMs de Axé, na visão de Pai Flávio, alterava, ainda, o papel inicialmente idealizado da associação, que focava na prestação de serviço e assistência religiosa. Esses oficiais, mais próximos e afinados com o comando da PMESP, conceberiam o grupo como um exemplo de boas práticas sobre a questão da intolerância religiosa na polícia militar. Capitalizavam politicamente a iniciativa, esvaziando-a religiosamente por consequência. Para Pai Flávio, a criação dos PMs de Axé era só o começo da luta contra a intolerância religiosa na corporação, não o resultado de sua ausência. 

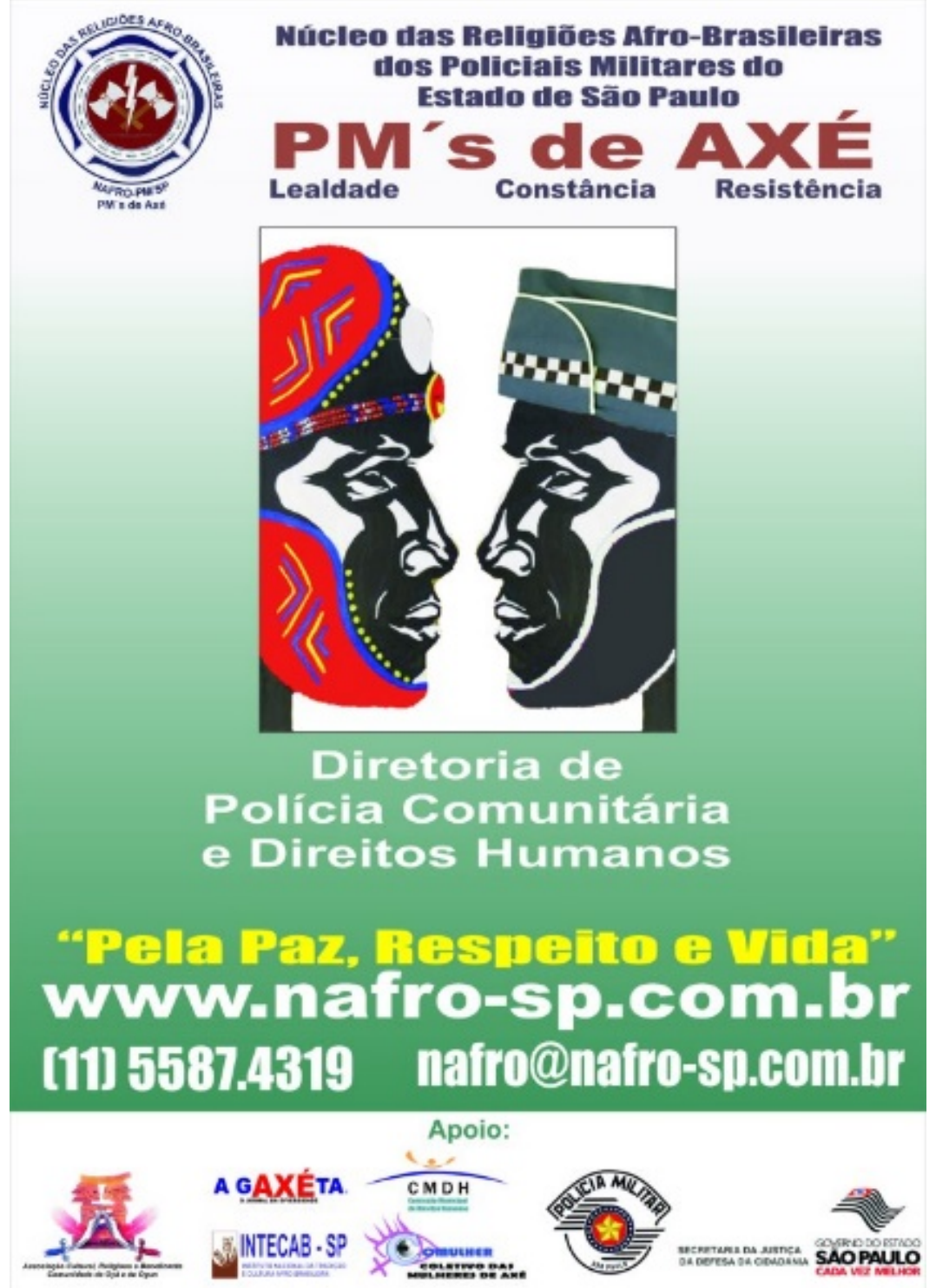

Imagem 08 - Cartaz de divulgação dos PMs de Axé no âmbito interno da PMESP.

(Fonte: Acervo Pessoal/Jornal A Gaxéta)

Ainda em 2009, ocorreriam dois fatos importantes: no primeiro, Pai Flávio conta que recebeu o telefonema de dois policiais da APMBB que, no âmbito dos seus cursos de especialização, desejavam fazer uma pesquisa sobre as atividades dos PMs de Axé como trabalho de monografia do curso. Pai Flávio teria aceitado - e ficado orgulhoso pelo reconhecimento do grupo, como me confessou. Agendou um horário para receber os policiais, decorou o terreiro, mandou preparar uma mesa farta e se paramentou. Os policiais realizaram uma entrevista de quatro horas, comeram, se despediram e foram embora, com o compromisso de disponibilizarem o trabalho final. Com a demora em receber o trabalho, Pai Flávio começou a insistir de forma mais 
incisiva, fazendo requerimentos diretos aos oficiais responsáveis pelas escolas de formação, sem obter resposta

No segundo, Pai Flávio teve conhecimento que uma vizinha do seu terreiro havia recebido a visita de uma policial militar, que buscava obter informações sobre o funcionamento do terreiro. A vizinha disse que havia conseguido enxergar escrito na prancheta da policial a seguinte anotação: “um centro de macumba, frequentado por PMs e veados”. Pai Flávio “ligou os pontos”, como me disse, e deduziu que estava sendo alvo de uma investigação social. Encaminhou um ofício ao então Comandante Geral Coronel Camilo, do qual não obteve resposta. Recorreu, em uma última tentativa, ao deputado estadual Major Olímpio (PDT-SP), velho conhecido de ALESP, para que levasse o caso ao Comandante Camilo. Transcrevo parte do ofício enviado ao deputado, com a devida autorização de Pai Flávio

Gostaríamos que V.Sa ficasse sabendo, de maneira escrita e assumida,
que fomos assediados por um PROCEDIMENTO chamado
'INVESTIGAÇÃO SOCIAL', onde nossa vida particular foi
vasculhada por PMs, na Comunidade. Temos a precisa e rigorosa
informação de que uma Cabo PM, de cor negra, redigiu um relatório
durante as investigações, constando: “um centro de macumba,
frequentado por PMs, e homossexuais [Pai Flávio me confessou que
alterou o termo em nome da formalidade]. De certo, uma conclusão
bastante preconceituosa e inconstitucional. [...] Como V.Excia pode
ver, não há como nosso COMANDANTE GERAL não ficar sabendo
da conduta de alguns de seus subordinados, isto sem citar que a
legislação exige a participação da sociedade civil na construção de
projetos dentro da PMESP. Mas perguntamos: QUAL SOCIEDADE
CIVIL A PM PRECISA? Achamos de alto importância que nunca
fomos formalmente evitados, mas a ausência de respostas, mesmo que
na negativa, e a indiferença são ‘parentes' do desprezo que, por sua vez,
é amante da discriminação.

Pai Flávio ficou particularmente magoado com a situação toda, como é possível perceber. Semanas depois, Pai Flávio receberia o trabalho das mãos de uma aluna da APMBB: um documento de 35 páginas, com a transcrição da entrevista realizada com ele e uma introdução teórica de duas páginas; e nenhuma explicação sobre o caso da investigação social. Denunciou o caso na AG, o que acabou por piorar a já delicada situação dos PMs de Axé com a corporação. No mesmo período, no final de 2010, chegava ao fim outra batalha de sua vida: após 13 anos de disputas na 
subprefeitura de Vila Mariana, foi impedido de continuar exercendo seus cultos no imóvel onde morava havia mais de 30 anos. Mudou-se para um sítio na zona rural da cidade de Mogi das Cruzes, onde reside até hoje. Com o afastamento de Pai Flávio, as atividades dos PMs de Axé arrefeceram, continuando apenas o vínculo junto à DPCDH. Na AG de junho de 2013, a última palavra de Pai Flávio a respeito dos PMs de Axé:

Trabalhamos muito pela dignidade dos Cultos Afros. Principalmente em SP. Fomos, a priori, muito bem recebidos pela Diretoria de DH da PMESP, na época Major Justus e Major Clarice. Porém, Oficiais não preparados assumiram a Diretoria citada e tudo ficou parado. Nos quartéis a liberdade religiosa não existe, $\mathrm{O}$ Estado Laico não é respeitado e a perseguição religiosa e a discriminação correm solta. Certa vez, um oficial "careca", argumentou que não podia aceitar que nossa religião iniciava deixando os noviços carecas, pois a falta de cabelos fugia do padrão militar. Perguntei a ele, então como ele fazia!!!!!! O NAFRO é uma ação concreta contra a Intolerância Religiosa. Não é teoria e não tem 'panelinha'....Está um pouco inativo, mas se fortalecendo para voltar com tudo! Epahey Oyá...Patrona do NAFRO-SP...Podem esperar! (AG 06/13) 


\section{Capítulo 3:}

\section{A RELIGião, A POLÍ́CIA E o POLICIAL}

\section{Os grupos religiosos sob a hierarquia militar}

Conhecendo os grupos, resta agora desdobrar, a partir de uma interpretação sociológica, quais os fatores que influenciaram, influenciam e qualificam a persistência destes grupos no interior da corporação policial. É responder, por exemplo, às perguntas: por quê um grupo religioso tem mais 'sucesso' na sua empreitada do que outro? O que explica a derrocada dos católicos e a constância dos espíritas kardecistas? Como os evangélicos, ao mesmo tempo em que tanto se expandem, não conseguem angariar um reconhecimento institucional (leia-se: burocrático) de fato?

Seria tentador responder a essas perguntas analisando as dinâmicas do campo religioso brasileiro, suas tensões e seus conflitos, e colocar os grupos religiosos da PMESP sob a mesma perspectiva. Tal empreitada, no entanto, não traria respostas satisfatórias, ainda que essas dinâmicas possam, em parte, coincidir - e irão coincidir, se lembrarmos de que "existem homologias estruturais e funcionais entre todos os campos”, conforme nos lembra Bourdieu (1989: p. 67). Mas a dinâmica do campo religioso na caserna, justamente por estar subordinada, arrisco dizer, à mais efetiva dimensão da vida organizada, que é a burocracia militarizada, posiciona seus agentes no campo religioso de forma sui generis, onde a hierarquia militar altera de forma incisiva a sua configuração. 
Desta forma, questões como a postura persecutória dos neopentecostais e os pentecostais às religiões afro-brasileiras (Prandi: 2001, Mariano: 2003), as tensões entre os agentes e atores do próprio campo evangélico (Almeida: 2012) e as transformações deste campo (Mariano: 2005), a virada despolitizada do catolicismo na sua versão renovada (Prandi: 1996, Prandi; Souza: 1997) ou a efetivação de um espiritismo kardecista eminentemente religioso (Arribas: 2010), todas essas tensões e disputas simbólicas influenciam e moldam a configuração dos grupos religiosos no interior da corporação policial, mas devem ser analisados, aqui, pela dimensão militar que transversa as relações neste contexto.

Nesse sentido, a intenção neste capítulo é analisar de que forma essas peculiaridades do campo religioso militarizado, por assim dizer, determinam e conformam os grupos religiosos já apresentados dentro deste universo mais restrito. Assim, parto da análise do conceito de campo religioso como proposto pelo sociólogo francês Pierre Bourdieu, bem como da sua interpretação da sociologia da religião de Max Weber e, é claro, das ideias do próprio Weber, para pensar as relações envolvidas entre os agentes inseridos nessa dinâmica. Especificamente, são três as perguntas que procuro responder neste capítulo: como a hierarquia militarizada reconfigura o campo religioso, sua dinâmica e configuração; como alguns grupos são mais bem-sucedidos do que outros; e como, nessas condições, o religioso se dissolveu (ou ainda se dissolve) na corporação.

Para responder essas perguntas é necessário, em primeiro lugar, compreender o papel crucial que a hierarquia militar exerce na configuração deste campo religioso específico. Todos os grupos aqui analisados possuem, na composição da sua classe dirigente, oficiais de nível superior. Soma-se a isso o fato de que essas composições são praticamente imutáveis no tempo, durante todo o intervalo analisado até aqui. Podemos dizer, nesse sentido, que os sistemas de dominação e reprodução do campo religioso no interior da PMESP são ‘engessados’, na medida em que não se renovam - ou, poderíamos dizer, não se diversificam: sua mensagem permanece inalterada, seus sacerdotes não são substituídos e os detentores do monopólio dos bens de salvação não se alternam. 
Mas, se permanece imutável, por que deveria ser diferente? Em que medida é possível considerar essa característica como intrínseca aos grupos religiosos organizados dentro da corporação policial, como um fato que deve ser observado e analisado sociologicamente? Para responder essas questões, proponho analisar a configuração destes grupos à luz da relação entre o profeta, o mago e o sacerdote, tipos puros de atores do fazer religioso, tal qual formulada por Weber.

Weber elenca três tipos puros de atores religiosos: o mago, o profeta e o sacerdote. A distinção entre o papel do mago e do sacerdócio é a mesma que se pode estabelecer entre a magia e a religião (ou o culto), a primeira como "coação mágica” do sensível, manipulação de suas capacidades em proveito pessoal ou personalista; e a segunda como sistematização e relação com o suprassensível através de "súplicas, sacrifícios e veneração” (Weber, 2000: 293-294).

Weber apresenta uma série de características que definiriam o sacerdote típico. Weber coloca esses atores, por exemplo, como aqueles "funcionários profissionais que, por meios de veneração, influenciam os deuses”, ou ainda como “os funcionários de uma empresa permanente, regular e organizada, visando à influência sobre os deuses”. Outra característica, ainda, seria a de que

os funcionários exercem sua função, seja esta hereditária ou baseada em contrato individual, a serviço de uma associação com base em relações associativas de natureza qualquer, isto é, como empregados ou órgãos desta e no interesse dos seus membros (Weber, 2000: 294).

Weber ainda coloca os sacerdotes como “capacitados por seus saberes específico, sua doutrina fixamente regulada e sua qualificação profissional”. Todas essas características, diz Weber, poderiam também ser encontradas em maior ou menor grau nos magos ou nos profetas. Como contraponto a estas características, para Weber, o mago seria o ator que tem a capacidade de forçar “os 'demônios' por meios mágicos, que se valem da "utilização individual e ocasional” destes mesmos poderes. Para precisar o potencial distintivo dessas descrições, no entanto, já que tais oposições podem ser "inteiramente fluidas, como ocorre em quase todos os fenômenos sociológicos”, Weber ressalta a necessidade de se levar em conta, na atuação dos 
atores religiosos, “a adaptação de um círculo especial de pessoas ao exercício regular de culto, vinculado a determinadas normas, a determinados tempos e lugares a que se refere determinadas associações” (p. 294-295).

É, porém, na figura do profeta que Weber vai enxergar a oposição diametral ao sacerdote. Weber define o profeta como "o portador de um carisma puramente pessoal, o qual, em virtude de sua missão, anuncia uma doutrina religiosa ou um mandado divino” (p. 303). O profeta é o portador de uma mensagem que, seja por ser nova em relação à mensagem já rotinizada pelo sacerdócio (novidade “de fato ou suposta”), ou por anunciar em outros termos uma revelação já interpretada, reclama a autoridade religiosa, cuja legitimidade vem de "sua revelação pessoal ou de seu carisma”. Sistematizando essa relação, Pierucci sublinha que

O sacerdote, como membro de um empreendimento de salvação com caráter de associação, é legitimado por seu cargo; já o profeta, assim como o feiticeiro carismático, atua apenas em virtude de seus extraordinários dotes pessoais. O profeta, por sua vez, distingue-se do feiticeiro pelo fato de que a substância de sua missão não consiste em manipulação interesseira de poderes sagrados, mas em doutrinas ou imperativos éticos (Pierucci, 1998: 56)

É exatamente no conceito de carisma - ou o que se pode apreender dessa noção nas relações de dominação -que se dá, talvez, a maior flexão que Bourdieu vai realizar na obra de Weber, na célebre interpretação operacional que o sociólogo francês propõe ao tratar da gênese e estrutura do campo religioso (Bourdieu: 2007). Para Weber, o carisma se define como

uma qualidade pessoal considerada extra-cotidiana e em virtude da qual se atribuem a uma pessoa poderes ou qualidades sobrenaturais, sobrehumanos ou, pelo menos, extra-cotidianos específicos, ou então se a toma como pessoa enviada por Deus, como exemplar e, portanto, como ‘líder’ (Weber, 2000: 159).

O poder - ou a dominação - pelo carisma está, para Weber, na posição diametralmente oposta ao poder exercido em nome da legalidade - cujo poder é reconhecido em determinado indivíduo a partir da validade e da legitimidade dos 
regulamentos que conferem tal poder - e se difere do poder exercido a partir da tradição, cuja legitimidade repousa nos costumes e na repetição sistemática do exercício de poder. Segundo Julien Freund, o carisma "repousa no abandono dos membros ao valor pessoal de um homem que se distingue por sua santidade, seu heroísmo ou seus exemplos” (Freund, 2003: 167).

Bourdieu, por sua vez, questiona o caráter pessoal do carisma, tencionando “acabar de vez com a representação do carisma como propriedade associada à natureza de um indivíduo singular” (Bourdieu, 2007: 74). Para Bourdieu, é necessário encarar a relação do profeta e de seu carisma em uma situação relacional que articula, além dele, os leigos e o próprio sacerdote. Além disso, para Bourdieu, Weber acabaria por "sujeitar-se à representação ingênua do carisma como qualidade misteriosa da pessoa ou dom natural” (Bourdieu, 2007b: 94), quando, na verdade, o que está em jogo - e jogo no sentido bourdieusiano do conceito - é a disputa que se dá, dentro do campo religioso, pelo status de autoridade religiosa, em uma relação que regula oferta e demanda dos bens de salvação. É nesse sentido que Bourdieu afirma que

\footnotetext{
Enquanto a autoridade do profeta, autor cuja auctoritas deve sempre ser conquistada ou reconquistada, depende da relação que se estabelece a cada instante entre a oferta de serviço religioso e a demanda religiosa do público, o sacerdote dispõe de uma autoridade de função que o dispensa de conquistar e de confirmar continuamente sua autoridade e o protege das consequências do fracasso de sua ação religiosa..(Bourdieu, 2007b: 90).
}

Assim, são nas posições que esses atores (ou agentes, para ficar mais fiel ao léxico de Bourdieu) ocupam nessa estrutura que se dão as disputas inerentes ao campo religioso, não nas propriedades individuais destes atores. O campo religioso, enquanto reprodução da vida social, define-se, dessa forma, pela disputa em torno do monopólio dos bens de salvação: na dialética entre o carisma rotinizado pelo sacerdote (e, portanto, não figurando mais como carisma) e a revelação nova que o profeta vem trazer.

É exatamente à essa relação que me referi anteriormente como engessada. Ao submeter as revelações à lógica militar, qualquer assunção de um profeta como agente 
de um campo é impensável, pelo próprio fato de que tal posição no campo não é colocada. Ao ordenamento hierárquico militar não cabe interpretações ou reinterpretações que não aquelas referendadas pelo comando, já que qualquer ruptura no ordenamento do campo religioso irá, muito provavelmente, questionar o próprio ordenamento militar.

Isso fica por demais evidente no caso dos PMs de Cristo, na sua primeira versão pacifista. Ao questionar a legitimidade do uso da força como contrário à ética judaico-cristã, aqueles primeiros policiais, talvez sem saber, questionavam a própria função do Estado moderno tal qual definido por Weber, além da própria legitimidade da polícia enquanto corporação. Ao inaugurar aquele pequeno grupo de orações dentro do quartel policial, aqueles policiais estavam inserindo uma nova concepção, revelada somente a eles, de policiamento. Na impossibilidade de contrastar essa incompatibilidade de forma tão magistral quanto Weber, cito-o em uma passagem longa, porém extremamente elucidativa:

Em oposição a toda espécie de organização administrativa burocrática, a estrutura carismática não conhece nenhuma forma e nenhum procedimento ordenado de nomeação ou demissão, nem de "carreira" ou "promoção"; não conhece nenhum "salário", nenhuma instrução especializada regulamentada do portador do carisma ou de seus ajudantes e nenhuma instância controladora ou à qual se possa apelar; não lhe estão atribuídos determinados distritos ou competências objetivas exclusivas e, por fim, não há nenhuma instituição permanente e independente das pessoas e da existência de seu carisma pessoal, à maneira das "autoridades" burocráticas. Ao contrário, o carisma conhece apenas determinações e limites imanentes. O portador do carisma assume as tarefas que considera adequadas e exige obediência e adesão em virtude de sua missão. Se as encontra, ou não, depende do êxito. Se aqueles aos quais ele se sente enviado não reconhecem sua missão, sua exigência fracassa. Se o reconhecem, é o senhor deles enquanto sabe manter seu reconhecimento mediante "provas". Mas, neste caso, não deduz seu "direito" da vontade deles, à maneira de uma eleição; ao contrário, o reconhecimento do carismaticamente qualificado é o dever daqueles aos quais se dirige sua missão. [...] $\mathrm{O}$ carisma pode ser, e naturalmente é, em regra, qualitativamente singular, e por isso determina-se por fatores internos e não por ordens externas o limite qualitativo da missão e do poder de seu portador. Segundo seu sentido e conteúdo, a missão pode dirigir-se, e em regra o faz, a um grupo de pessoas determinado por fatores locais, étnicos, sociais, políticos, profissionais ou de outro tipo qualquer: neste caso, encontra seus limites no círculo destas pessoas. Assim como em todos os demais aspectos, a dominação carismática é também em seu fundamento 
econômico exatamente o contrário da dominação burocrática. Enquanto esta última depende de receitas constantes e, portanto, pelo menos $a$ potiori, da economia monetária e de contribuições em dinheiro, o carisma, apesar de viver dentro deste mundo, não vive dele. (Weber, 1999: 323-324).

Foi exatamente neste sentido que o grupo evangélico foi, então, restruturado. A mensagem necessitaria passar pelo crivo do comando policial: era necessário submeter o carisma à burocracia, e foi o que aconteceu. A mesma lógica explica, em parte a dificuldade de inserção dos PMs de Axé. Pai Flávio não esconde que o tempo todo tentou inserir discussões sobre preconceito de cor e de orientação sexual, intolerância religiosa e perseguição na polícia, temas, por assim dizer, delicados para a corporação. Mas, mais do que isso, a tentativa de substituição da hierarquia militar pela religiosa foi, a médio prazo, o principal elemento que dificultou o estabelecimento completo do grupo. A tentativa de captação do grupo como exemplo de boas práticas da PMESP, conforme relatou Pai Flávio, foi a tentativa mesma de submissão do carisma e das profecias à burocracia da corporação.

Já a capelania católica, clerical desde a sua concepção no Brasil imperial, pôde subsistir e subsiste até hoje pela extrema diferenciação entre essas duas esferas. A atuação do capelão católico nunca foi outra senão a continuidade do seu sacerdócio na igreja romana. Os concursos para padre capelão buscavam e buscam inserir profissionais da fé exógenos à corporação militar, resultando que tais profissionais, mesmo ocupando patentes do oficialato, nunca foram enxergados como companheiros de caserna, mas sim como sacerdotes a serviço das forças armadas e singulares. Se se encerrou este papel, no caso da PMESP, foi a queda individual do sacerdote, não sua mensagem, e por um motivo, ao que tudo indica até agora, extremamente racionalizado de atuação.

Prosseguindo, os PMs a Caminho da Luz, neste sentido, apresentam-se, como já mencionado, como o mais regular exatamente por que seus sacerdotes (sabendo que os kardecistas irão discordar do termo) e sua mensagem nada têm de profético. Não ameaçam justamente pelo fato de que não buscam inserir uma agenda - como é o caso dos PMs de Axé - ou propor novos padrões de policiamento, caso dos primeiros PMs 
de Cristo. O estilo low profile do grupo e a sua absoluta revelia a discutir o papel da polícia, do policial e da violência. Quando se propõe a curar almas e sistematizar uma ética, baseada nos evangelhos de Kardec, o fazem tendo em vista temas gerais da existência e da vida em sociedade. Por esse motivo, talvez, o grupo, a despeito de sua constância e da sua permanência na corporação, seja aquele onde a identidade do seu séquito de participantes seja a mais heterogênea possível, ao ponto de que, não fosse o fato de as reuniões se darem na sede da APMBB, talvez não fosse possível perceber suas origens militares.

\section{A religião como justificativa da tarefa policial}

Se, dentre todos os grupos, o dos evangélicos foi o mais bem-sucedidos nas estratégias de inserção e são aqueles que mais se multiplicam, resta-nos entender o porquê. É na virada discursiva da primeira formação do grupo para a seguinte (aquela que seria vinculada ao comando) que se encontra uma das explicações. Se, como nos lembra Weber (1999), a religião sempre cumpre a função de conservação da ordem social, foi necessária uma adaptação dos ensinamentos e das mensagens religiosas à ordem do micro (médio?) cosmo da corporação policial militar. Neste ponto concorda Bourdieu, quando afirma que

\footnotetext{
a análise da estrutura interna da mensagem religiosa não pode ignorar impunemente as funções sociologicamente construídas que ela cumpre: primeiro, em favor dos grupos que a produzem e, em seguida, em favor dos grupos que a consomem (Bourdieu, 2007a: 43).
}

O discurso de paz, ou a condenação pública das práticas policiais daquele momento de crise institucional da PMESP, foi substituído, aos poucos, por um discurso calcado principalmente em duas dimensões: a legitimidade da autoridade policial perante Deus; e a proteção espiritual que poderiam usufruir os policiais militares que estivessem em comunhão com esse mesmo Deus. Diz Bourdieu, ainda, em uma passagem elucidativa dessa transformação, que uma das funções sociais da 
religião - e que a tornaria passível, neste sentido, de uma sociologia de suas estruturas - é sua capacidade, enquanto sistema estruturado de ação, transformação do ethos, "enquanto sistema de esquemas implícitos de ação e de apreciação", em ética, “enquanto conjunto sistematizado e racionalizado de normas implícitas” (2007a: 46).

Assim, "ao submeter o sistema de disposições em relação ao mundo natural e ao mundo social (disposições inculcadas pelas condições de existência) a uma mudança de natureza”, a estruturação dos evangélicos em uma posição dominante no campo religioso militarizado consegue transformar, do ponto de vista subjetivo, a ideia da profissão de policial militar enquanto guerreira, masculina e na fronteira entre a sociedade e o "mundo do crime" em uma profissão abençoada e legítima aos olhos de Deus: uma ética policial calcada na responsabilidade dada diretamente por Deus de construir, pela autoridade legal, uma sociedade mais justa e menos violenta. Isso se daria, continuando com Bourdieu, pelo fato de que

os leigos não esperam da religião apenas justificações de existir capazes de livrá-los da angústia existencial da contingência e da solidão, da miséria biológica, da doença, do sofrimento ou da morte. Contam com ela para que lhes forneça justificações de existir em uma posição social determinada, em suma, de existir como de fato existem, ou seja, com todas as propriedades que lhes são socialmente inerentes (Bourdieu, 2007a: 48).

Assim, a expressão fenomenológica da religião daqueles primeiros evangélicos era a não-contaminação com as imperfeições de uma instituição que se colocava e ainda se coloca como capaz de transformar e melhorar uma sociedade imperfeita. A violência inerente à profissão - seja no grau mínimo da possibilidade do recurso à força, ou no seu grau máximo com os grupos de extermínio que pipocavam no final da década de 90 - deveria ser evitada ao máximo. Este é, no senso comum e mesmo nos círculos acadêmicos, o engano mais sedutor que se pode cair ao analisar essa questão: a de que a mensagem religiosa, especialmente a evangélica, é capaz de neutralizar a violência cotidiana que é a função e razão de ser da própria corporação e do Estado (para não nos esquecermos de Weber e Elias). A chave para fugir a este engano é pensar que uma religião que se desenvolve no seio das polícias 
e das forças armadas só pode subsistir enquanto mantenedora das suas dimensões estruturantes. Nesse ponto, diz Bourdieu:

\begin{abstract}
basta construir o fato religioso de maneira especificamente sociológica, isto é, como a expressão legitimadora de uma posição social, para que se percebam as condições sociais de possibilidade, e portanto os limites, dos demais tipos de construção, sobretudo daquela que podemos chamar fenomenológica a qual, em seu esforço por submeter-se à verdade vivida da experiência religiosa enquanto experiência pessoal irredutível às suas funções externas, esquece de operar uma última "redução", qual seja a das condições sociais que devem ser preenchidas para que seja possível esta experiência vivida (Bourdieu, 2007a: 49).
\end{abstract}

Na esteira dessa análise, é possível afirmar, então, que é somente o grupo dos evangélicos que assume em sua mensagem religiosa a função de justificar a atividade policial, considerando o alheamento dos kardecistas, a neutralidade do sacerdócio católico e a oposição e questionamento dos afro-brasileiros. Neste sentido, ocorre todo um esforço por parte dos evangélicos de sistematização da reprodução dessa visão justificadora da profissão policial, através, em primeiro lugar, da capacitação dos encarregados pela reprodução e, em um segundo momento, da sistematização de um corpus doutrinário cuja mensagem fosse essa.

\title{
$O$ religioso no papel de policial
}

Como exemplo deste esforço, temos os já citados livros A missão de Deus para o Policial (Barreto Neto, 2012); Com o sacrifício da própria vida (Terra; Silva, 2007); e A Polícia e a Igreja: uma parceria para o desenvolvimento da comunidade e o combate à violência (Alves, 2012). Todos eles buscam, em algum momento, demonstrar a afinidade eletiva entre autoridade policial e autoridade divina. No livro de Terra e Silva, por exemplo, há um capítulo chamado "É possível ser policial e caminhar com Cristo?”.

Neste livro, os autores discorrem sobre as diversas noções de autoridade presente nas escrituras bíblicas, desde a autoridade de Jesus Cristo em operar milagres 
e expulsar demônios até a autoridade do centurião que, no livro de Lucas, é exaltado

pela sua grande fé. Os autores comparam essas noções de autoridade com aquela exercida pelo policial:

O policial além de autoridade pública é também uma autoridade de Deus. Tem o divino chamado de ser instrumento do bem e da justiça. Em seu trabalho cumpre uma missão dada por Deus: a de opor-se às obras do mal; o roubo, a morte e a destruição (João 10.10). Nisso reside o caráter divino e também pedagógico dessa nobre missão. O policial é o "seu guarda", uma referência de coragem, heroísmo e conduta positiva no consciente coletivo (Terra; Silva, 2007: 63)

Da mesma forma, problematizam a questão do uso da violência. Utilizam como comparação a passagem narrada pelo evangelista Marcos em que Jesus Cristo, irritado com o grande número de comerciantes que circundavam o templo de Jerusalém, expulsou-os a chicotadas. Sobre a passagem, dizem os autores:

Aquele lugar era uma casa de oração e não lugar de negócios. Assim, Ele agiu com firmeza e usou os meios necessários para colocar ordem na Casa de Deus, expulsando os vendilhões do templo. O policial deve agir sempre nos limites da lei, utilizando moderadamente os meios necessários para repelir a injusta agressão em curso ou iminente. Deve vigiar para não cair no engano de ser usado por grupos da sociedade que querem "terceirizar a vingança", utilizando-o como instrumento. Quando a vida de alguém ou a sua própria estiver em perigo, como último recurso, ele poderá se ver obrigado a fazer uso da força letal, causando infelizmente a morte do agressor. Mas ele deve sempre se lembrar que não é recrutado para matar e essa ocorrência deve ser acidental em sua vida e não desejada ou procurada. O respaldo está na legitimidade da ação (p. 64-65)

O livro de coronel Barreto Neto, da mesma forma, faz uma análise teológica da noção de autoridade como fonte de legitimidade da ação policial. A ameaça à autoridade consistiria, para o coronel, como fator desintegrador da sociedade e das relações sociais.

A autoridade é necessária em todos os segmentos da sociedade. Na escola ela se apresenta no relacionamento entre o professor e o aluno. No trabalho, entre o funcionário e seu chefe. Para reger todos os relacionamentos entre superiores e subordinados e demais pessoas entre si, foram criadas as leis e delegada autoridade a determinadas pessoas que devem policiar outras pessoas, para que estas não extrapolem os limites legais. Este poder, dado a determinadas pessoas para policiarem 
outras, chamamos de 'Poder de Polícia'. É um poder que está presente na escola, na figura do inspetor de alunos; na praia, na figura do guardavidas; no cinema, na figura do lanterninha; na igreja, na figura do diácono; e nas ruas, na figura dos policiais. (Alves, 2012: 23-24)

Chama a atenção como os discursos são afinados. Alves aprofunda a análise e, em um discurso um tanto mais encantado do que o de seus colegas de grupo e de farda, atribuindo à ação diabólica a competência de questionamento das autoridades várias que sustentam, na visão dele, o tecido social. Vejamos:

O diabo, consciente da importância da autoridade para a vida do ser humano, tem procurado a cada dia vilipendiar e envilecer toda e qualquer autoridade. Quando um determinado pai erra, isto não significa que a família esteja errada. Quando um determinado político erra, isto não significa que todos os políticos sejam errados. Quando um policial erra, não é a instituição polícia que errou, mas sim o policial. E quem é o policial? Alguém recrutado em Marte, no céu ou no inferno? Todos os nossos policiais são recrutados no seio da sociedade. Quando um policial erra, não é a polícia que errou, mas sim a sociedade. Ao recrutarmos um policial, gastamos meses para moldá-lo nos padrões desejáveis para um bom policial. Porém, tente imaginar a dificuldade que nossas escolas de formação têm para entregar à sociedade um bom policial. Ela terá que moldar e recuperar em nove meses aquilo que o meio social levou de dezoito a trinta anos deformando ou destruindo, pois esta é a idade para ingresso em nossa corporação (Alves, 2012: 26).

A visão de Alves consegue, ao mesmo tempo, personalizar os problemas e desvios institucionais que as polícias militares apresentam e inimputabilizar o policial que comete algum delito ou excesso, já que o problema seria da estrutura social de modo mais amplo. Para Alves, uma concepção contrária seria uma ação orquestrada, principalmente pela imprensa, de generalização dos comportamentos, e não da individualização das atitudes (Alves, 2012: 27). A questão apontada é exatamente o contrário: a autoridade policial é revestida pela autoridade divina e, logo, duplamente inquestionável, já que “quando um cidadão é investido na autoridade policial, no mundo espiritual também é empossado como autoridade espiritual e passa a ser um servo de Deus”.

A suposta incompatibilidade entre ação policial e pertença religiosa, já mencionada acima, também é tratada por Alves no capitulo intitulado “Não matarás”. 
Nele, o próprio comandante se propõem a desfazer essa confusão, colocando a questão em primeira pessoa:

Logo que entrei para a polícia, muitas pessoas me perguntavam: "E se você tiver que matar alguém?” Talvez esta pergunta também ronde sua cabeça e você já tenha perguntado: "Será que um cristão pode ser um policial, mesmo sabendo que eventualmente poderá ter que matar alguém?” (Alves, 2012: 31).

É nas leis do antigo testamento que, segundo o policial, encontra-se a resposta, mais precisamente no livro de Êxodo, capítulo 22, versículo 2, que diz: Se um ladrão for achado arrombando uma casa e, sendo ferido, morrer, quem o feriu não será culpado de seu sangue”. A legitimidade da ação, neste caso, funcionaria como o pêndulo da justiça na avaliação dos casos onde a ação policial resultasse em morte. Essa visão concilia em definitivo a mensagem religiosa dos PMs de Cristo com a atividade policial. Transcrevo outro trecho, este um pouco mais longo, em que essa conciliação é radicalizada:

Como deve então agir o policial, para não ferir o mandamento de Deus? Deverá ele agir dentro da lei. Se ele vier a matar alguém, esta ação deverá ser amparada por um dos excludentes das ilicitudes. Neste caso, o policial, ao matar o agressor da sociedade, agirá exercendo o juízo de Deus contra ele. No capítulo 20 do livro de Levítico, são descritos diversos tipos penais da lei de Deus, e em diversos deles a pena era a de morte por apedrejamento. E quem executava o apedrejamento não estava matando? E por que não era punido? Simplesmente porque estava no exercício da justiça determinada por Deus, agindo no estrito cumprimento do dever legal. O policial não é recrutado para matar, porém, se em algum momento, a vida de alguém ou de si próprio estiver em perigo, o policial deverá usar os meios necessários para conter a injusta agressão. Se necessário for, ele matará o agressor, exercendo assim o juízo que por Deus lhe foi outorgado. Um juiz terá dias ou até anos para estudar um processo, para então condenar alguém a alguns anos na prisão. Embora não tenhamos a pena de morte em nosso código penal, o policial terá, no exercício de sua função, e muitas vezes em questão de segundos, que julgar e, se necessário for condenar à morte. Ele, como policial, executa algo que nenhum juiz no mundo pode fazer: julgar e ao mesmo tempo executar juízo. Embora preste um serviço ímpar à sociedade, muito pouco é por ela valorizado. (Alves, 2012: 32).

Essa visão iria impactar profundamente o grupo dos PMs de Cristo, alterando a agenda do grupo para uma visão mais próxima da valorização do policial militar e 
da importância dos laços de fraternidade e familiares para cada um destes indivíduos. Ao invés de se isolarem da realidade violenta da sociedade brasileira, a atuação dos PMs de Cristo se efetivaria pela oração e intercessão por essa mesma sociedade. 


\section{CONCLUSÃO}

Religião e polícia aparentemente são termos que não combinam. A polícia usa da violência com legitimidade, submete seus agentes à necessidade de matar, vive mergulhada no submundo do crime, suja as mãos com tudo que há de menos nobre e tolerável. Tudo o que a religião, sobretudo quando essa não advoga a luta armada e a guerra, abomina; contra o que a religião professa. Ao mesmo tempo, para os professionais policiais que vivem nesse fio da navalha, a religião pode representar um bálsamo, um conforto, um arrimo ético, uma justificativa, enfim, da própria ação.

Numa sociedade como a nossa, onde religiões proliferam, acelerando conversões, mudando o sentido das crenças, incorporando setores sociais os mais díspares, constituindo-se, por conseguinte, como atores de um mercado de bens de salvação extremamente competitivo, é de se esperar que, mesmo no interior de uma instituição como a Polícia Militar, as diferentes ofertas religiosas se expressam e se expõem, procurando marcar sua presença e desenhar seu espaço que, historicamente, foi ocupado pelo catolicismo oficialmente mantido pelas antigas e hoje decadentes capelanias.

O presente trabalho é um estudo dos principais grupos e agentes religiosos atuantes, ou que pretendem atuar, no interior do quartel. Trata especialmente dos seguintes grupos e agentes: PMs de Cristo, formado pelos evangélicos; os PMs de Axé, adeptos das religiões afro-brasileiras; os PMs a Caminho da Luz, da vertente kardecista e o serviço de capelania católica. Cada um deles busca, a seu modo e pelas suas próprias estratégias, garantir ou manter privilégios, conquistar reconhecimento e 
legitimidade, enfim, ser visto como uma instituição religiosa que possui um papel e uma missão dentro da corporação.

Este trabalho pode ser interpretado sob diversas óticas. Pode ser visto como uma narrativa do declínio católico, da perda de sua tradicionalíssima hegemonia e respaldo junto ao aparelho estatal, ao ponto em que a própria diversidade religiosa da corporação policial, a exemplo do campo brasileiro de forma geral, não justifica mais uma relação tão estreita. Pode também ser visto como uma análise da transposição do campo religioso brasileiro para um lugar de atuações marcadas não somente pela posição dos agentes na configuração deste campo, mas onde essas posições são, antes de tudo, determinadas pela lógica de uma organização sujeita à hierarquia militar, avessa a qualquer tipo de inovações e transformações.

Pode ser visto, ainda, como uma interpretação da dissolução do religioso no interior da Polícia Militar do Estado de São Paulo que, ao inflar o seu quadro de terapeutas, psicólogos e assistentes sociais, demove a religião do seu pretenso papel de cura das almas. Ao prescindir da religião como terapêutica, a polícia militar pode se dar ao luxo de simplesmente desregular a sua atuação, diminuindo o seu espectro de atuação e de influência.

Seja como for, uma coisa é clara: nunca houve tantos religiosos atuando no interior da Polícia Militar do Estado de São Paulo; e nunca antes a religião esteve tão em baixa. A queda do último capelão foi o golpe final em uma relação que vinha dando sinais de desgaste, relação que é tão antiga quanto a existência da própria polícia. Nada mais significativo, nesse sentido, que as palavras trocadas entre o atual comandante Ricardo Gambaroni e o Secretário de Segurança Pública Alexandre de Moraes: "Nós conversamos sobre a desnecessidade desse cargo de capelão da polícia até em virtude da pluralidade religiosa”32, afirmou o secretário. A Polícia Militar do Estado de São Paulo secularizou-se.

\footnotetext{
32 Reportagem do portal de notícias G1. Disponível em: http://g1.globo.com/saopaulo/noticia/2015/05/suspeito-de-desviar-dizimo-capelao-e-preso-e-pode-ser-excomungado.html. Acesso em 17 de agosto de 2015.
} 


\section{REFERÊNCIAS BIBLIOGRÁFICAS}

ALBERNAZ, Elizabete Ribeiro. Na fronteira entre o bem e o mal: ética profissional e moral religiosa entre policiais militares evangélicos cariocas. Cadernos. $C R H$. 2010, vol.23, n.60, pp. 525-539.

ALBERNAZ, Elizabete. “Deus e o Diabo na terra do sol”: visões de espaço público, ética profissional e moral religiosa entre policiais militares evangélicos do Rio de Janeiro. Dissertação de mestrado em Antropologia, Museu Nacional, Universidade Federal do Rio de Janeiro, 2009.

ALMEIDA, Marcelo Coelho. A Religião na Caserna: o papel do capelão militar. Dissertação: Mestrado em Ciências da Religião - Universidade Presbiteriana Mackenzie, São Paulo, 2006.

ALMEIDA, Ronaldo de. Negócios, poder e fé: a Universal contra a Mundial. In: ORO, Ari Pedro; STEIL, Carlos Alberto; CIPRIANI, Roberto; GIUMBELLI, Emerson (Orgs.). Religião no espaço público: atores e objetos. São Paulo: Terceiro Nome, 2012.

ARRIBAS, Célia. Afinal, espiritismo é religião? A doutrina espírita na formação da diversidade religiosa brasileira. São Paulo: Alameda, 2010.

ARRIBAS, Célia. No princípio era o verbo: espíritas e espiritismos na modernidade religiosa brasileira. Tese de Doutorado. Universidade de São Paulo. 2014

BARRETO NETO, Custódio Alves. A missão de Deus para o policial. São José dos Campos: Inspire, 2012

BAYLEY, David. Padrões de policiamento. São Paulo: Edusp, 2006.

BIRMAN, Patricia. “Cruzadas pela paz: práticas religiosas e projetos seculares relacionados à questão da violência no Rio de Janeiro”. Religião e Sociedade, 32 (1). 2012

BOURDIEU, Pierre. Apêndice I: Uma interpretação da teoria da religião de Max Weber. In.:___ A economia das trocas simbólicas (5 a ed.). São Paulo: Perspectiva, 2007b.

BOURDIEU, Pierre. Gênese e estrutura do campo religioso. In.: das trocas simbólicas. São Paulo: Perspectiva, 2007a. A economia

BRITO, Felipe; OLIVEIRA, Pedro Rocha (orgs.). Até o último homem: visões cariocas sobre a administração armada da vida social. São Paulo: Boitempo Editorial. 2013.

BUENO, Samira. Bandido bom é bandido morto: a opção ideológico-institucional da política de segurança pública na manutenção de padrões de atuação violentos da polícia militar paulista. Dissertação: Mestrado em Administração Pública e Governo - Fundação Getúlio Vargas. 146 p. 2014. 
CACHONE, Altair. Capelania Evangélica. Monografia: Bacharelado em Teologia. Centro Universitário Filadélfia. 57 p. 2006.

CÔRTES, Mariana. O bandido que virou pregador: a conversão de criminosos ao pentecostalismo e suas carreiras de pregadores. São Paulo: Aderaldo \& Rotschild Editores/Anpocs, 2007

CRIVELARI, Ubiratan Nelson. A Importância do Profissional 'Capelão': Força Vital na Consolidação do Exército Brasileiro. Dissertação - Mestrado em Ciências da Religião. Universidade Presbiteriana Mackenzie. 82 p. 2008

DELLA CAVA, Ralph. Igreja e estado no Brasil do século XX: sete monografias recentes sobre o catolicismo brasileiro, 1916/1964. Estudos Cebrap, 12, abr./jun. 1975,p. 5-52.

DIAS, Camila C. Nunes. A igreja como refúgio e a Bíblia como esconderijo? Conversão religiosa, ambiguidade e tensão entre presos evangélicos e massa carcerária. Dissertação de Mestrado, Faculdade de Filosofia, Letras e Ciências Humanas, Universidade de São Paulo, São Paulo, 2005.

DURANTE, Marcelo Ottoni; OLIVEIRA JUNIOR, Almir. Vitimização dos policiais militares e civis no Brasil. Rev. Bras. Segur. Pública. São Paulo v. 7, n. 1, 132150 Fev/Mar 2013.

ELIAS, Norbert. Envolvimento e alienação. Rio de Janeiro: Bertrand Brasil, 1998.

FELTRAN, Gabriel de Santis. O legítimo em disputa: as fronteiras do "mundo do crime" nas periferias de São Paulo. Dilemas. Revista de Estudos de Conflito e Controle Social. v. 1, n. 1, p. 93-126, Rio de Janeiro: UFRJ. 2008

FERNANDES, Heloísa Rodrigues. Os militares como Categoria Social. São Paulo : Global Ed. 1979.

FERRAZ, Joana; FERNANDES, Darc. Crimes Policiais de Execução Sumária no Rio de Janeiro: um estudo de caso sobre a chacina de Vigário Geral, da Candelária e de Acari. URBANITAS-Revista de Antropologia Urbana. Ano, v. 2, 2005.

FISCHMANN, Roseli. A proposta de concordata com a Santa Sé e o debate na Câmara Federal. Educ. Soc., Campinas , v. 30, n. 107. p. 563-583 2009

FRESTON, Paul. Religião, desenvolvimento e violência. Interseções [Rio de Janeiro]. v. 13 n. 1, p. 116-125, jun. 2011.

FREUND, Julien. Sociologia de Max Weber. $5^{\mathrm{a}}$ ed, $1^{\mathrm{a}}$ reimp.. Rio de Janeiro: Forense Universitária, 2003.

GEERTZ, Clifford. A interpretação das culturas. Rio de Janeiro: LTC, 2008.

GIUMBELLI, Emerson. O fim da religião: dilemas da liberdade religiosa no Brasil e na França. São Paulo: Attar Editorial. 2002.

LIMA, Maria Elizabeth Antunes. A polêmica em torno do nexo causal entre distúrbio mental e trabalho. Psicologia em Revista,10 (14), p. 82-91. 2003 
MACHADO, Carly. "É muita mistura": projetos religiosos, políticos, sociais, midiáticos, de saúde e segurança pública nas periferias do Rio de Janeiro. Relig. soc. Rio de Janeiro , v. 33, n. 2, p. 13-36, Dec. 2013.

MACHADO, Carly. A igreja ajuda a UPP, e a UPP ajuda a igreja: reflexões sobre pacificação, religião e política a partir de uma igreja Assembleia de Deus na Baixada Fluminense. Trabalho apresentado no $37^{\circ}$ Encontro Anual da ANPOCS. Águas de Lindóia, São Paulo. 2013.

MACHADO, Carly. Pentecostalismo e o sofrimento do (ex-)bandido, Horizontes Antropológicos [Online], 42 | 2014, posto online no dia 15 Dezembro 2014, consultado em 14 março de 2015. Disponível em: http://horizontes.revues.org/721.

MACHADO, Carly. "É muita mistura": projetos religiosos, políticos, sociais, midiáticos, de saúde e segurança pública nas periferias do Rio de Janeiro. Relig. soc. 2013, vol.33, n.2, pp. 13-36 .

MAFRA, Clara. O problema da formação do "cinturão pentecostal" em uma metrópole da América do Sul. Interseções, Rio de Janeiro, v. 13, n. 1, p. 136-152, jun. 2011.

MAFRA, Clara; DE PAULA, Robson. O Espírito da Simplicidade: a cosmologia da Batalha Espiritual e as concepções de corpo e pessoa entre policiais pentecostais cariocas. Religião e Sociedade, v. 22, n. 1, p. 57-76, 2002.

MARIANO, Ricardo. Análise sociológica do crescimento pentecostal no Brasil. 2001 (285 f.) Tese (Doutorado em Sociologia) - Universidade de São Paulo, São Paulo, 2001.

MARIANO, Ricardo. Competição e pluralismo religiosos na esfera política: a concordata e a Lei Geral das Religiões. Anais do $34^{\circ}$ Encontro Anual da Anpocs - Caxambu-MG. 2010

MARIANO, Ricardo. Guerra espiritual: o protagonismo do diabo nos cultos neopentecostais. Debates do NER (UFRGS), Porto Alegre, v. ano 4, n. n. 4, p. 21-34, 2003.

MARIANO, Ricardo. Laicidade à brasileira: católicos, pentecostais e laicos em disputa na esfera pública. Civitas-Revista de Ciências Sociais, v. 11, n. 2, 2011.

MARIZ, Cecília. “O Demônio e os Pentecostais no Brasil”; In: BIRMAN, Patrícia; NOVAES, Regina; e CRESPO, Samira (Orgs.) O mal à brasileira. Rio de Janeiro: EdUerj, 1997.

MELLO, Walter Pereira de. O Capelão Militar: Interlocutor entre a religião e a guerra. Dissertação: Mestrado em Ciências da Religião - PUC-Goiás. 127 p. 2011

MORENO, Júlio César. A devoção a Santo Expedito na cidade de São Paulo: Descrição, inventário, manifestações. Dissertação: Mestrado em Ciências da Religião. São Paulo: PUC-SP. 2000. 
NEME, Cristina. A Instituição Policial na Ordem Democrática: o caso da Polícia Militar do Estado de São Paulo. 1999. (109 f.) Dissertação (Mestrado em Ciência s Políticas) - Universidade de São Paulo, São Paulo

NOVAES, Regina. Juventude, religião e espaço público: exemplos "bons para pensar" tempos e sinais. Relig. soc., 2012, vol.32, no.1, p.184-208.

PEDROSO, Regina Célia. Estado Autoritário e Ideologia Policial. São Paulo: Associação Editorial Humanitas, FAPESP. 2005.

PIERUCCI, Antônio Flávio e PRANDI, Reginaldo. A realidade social das religiões no Brasil. São Paulo, Hucitec, 1996.

PIERUCCI, Antônio Flávio. Liberdade de cultos na sociedade de serviços. Novos Estudos - CEBRAP, n. 44, p. 3-11, 1996.

PIERUCCI, Antônio Flávio. Secularização em Max Weber. Da contemporânea serventia de voltarmos a acessar aquele velho sentido. Revista Brasileira de Ciências Sociais, v. 13, n. 37, pp. 43-73. 1998

PIERUCCI, Antônio Flávio. Religião como solvente: uma aula. Novos estudos CEBRAP. 2006, n.75, pp. 111-127

PIOVEZAN, Adriane. O Manual de Oração da Força Expedicionária Brasileira: religiosidade e patriotismo diante da morte em combate (1944-1945). Anais do XXVI Simpósio Nacional de História - ANPUH • São Paulo, julho 2013

PRANDI, Reginaldo; SOUZA, André Ricardo de. "A carismática despolitização da Igreja Católica". In: Pierucci, Antônio Flávio; Prandi, Reginaldo. A realidade social das religiões no Brasil. São Paulo: Hucitec. 1996.

RAMPAZZO, Elenice. O santo no ar: a propagação da devoção ao Santo Expedito por Intermédio do programa de rádio 'Eli Corrêa'. Dissertação: Mestrado em Ciências da Religião - PUC-SP. 111 p. 2006.

ROSEMBERG, A. De chumbo e festim - uma história da polícia paulista no final do Império. São Paulo: Edusp, 2010.

SCHELIGA, Eva L. "E me visitastes quando estive preso”: sobre a conversão religiosa em unidades penais de segurança máxima. Dissertação (Mestrado em Antropologia Social) - PPGAS, Universidade Federal de Santa Catarina, Florianópolis, 2000.

SIMÕES, Pedro (org.). Filhos de Deus: assistência religiosa no sistema socioeducativo. Rio de Janeiro: ISER, 2010.

TERRA, Alexandre; SILVA, Miguel Adailton da. Com o sacrifício da própria vida. São Paulo: Associação dos Policiais Militares Evangélicos do Estado de São Paulo, 2007.

VITAL DA CUNHA, Christina. “Traficantes evangélicos”: novas formas de experimentação do sagrado em favelas cariocas. Plural (São Paulo. Online), São Paulo, v. 15, p. 13-46, Jan. 2008. Disponível em: 
<http://www.revistas.usp.br/plural/article/view/75226/78991>. Acesso em: 11 Ago. 2015.

VITAL DA CUNHA, Christina. Evangélicos em ação nas favelas cariocas: um estudo sócio-antropológico sobre redes de proteção, tráfico de droga s e religião no complexo de Acari. 2009a. 334 f. Tese (Doutorado) - Instituto de Filosofia e Ciências Humanas, Universidade do Estado do Rio de Janeiro, Rio de Janeiro, 2009.

VITAL DA CUNHA, Christina. Da macumba às campanhas de cura e libertação: a fé dos traficantes de drogas nas favelas do rio de janeiro. Revista TOMO. v. 14, p. 229-265, jan/jul. 2009b. Disponível em: <

http://www.seer.ufs.br/index.php/tomo/article/view/505/421>. Acesso em: 14 Jul. 2015

VITAL DA CUNHA, Christina. Religião e criminalidade: traficantes e evangélicos entre os anos 1980 e 2000 nas favelas cariocas. Religião e Sociedade. Rio de Janeiro, v. 34, n. 1, p. 61-93,junho / 2014.

WEBER, Max. Economia e Sociedade: Fundamentos da sociologia compreensiva. Tradução de Regis Barbosa e Karen Elsabe Barbosa. Brasília: Editora da UnB, vol. I, 2000.

WEBER, Max. Economia e Sociedade: Fundamentos da sociologia compreensiva. Tradução de Regis Barbosa e Karen Elsabe Barbosa. Brasília: Editora da UnB, vol. II, 1999.

ZALUAR, Alba A criminalização de drogas e o reencantamento do mal. Revista do Rio de Janeiro - Uerj, v. I, fasc. 1, 1993.

ZALUAR, Alba. O diabo em Belíndia. Religião \& Sociedade, Rio de Janeiro, n. 12/2, out.1985, p. 132-38.

ZYLBERSZTAJN, Joana. O princípio da laicidade na Constituição Federal de 1988. Tese - Doutorado em Direito do Estado, Universidade de São Paulo. 248 p. 2012. 